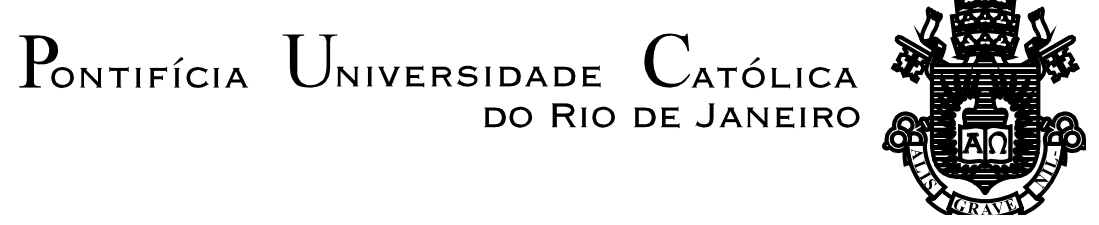

Rafael de Paula Taveira Rodriguez Meire

\title{
ESTILOS: ENTRE MACHADO E SEUS RECRIADORES
}

\section{Dissertação de Mestrado}

Dissertação apresentada ao Programa de PósGraduação em Literatura, Cultura e Contemporaneidade da PUC-Rio como requisito parcial para obtenção do título de Mestre em Letras/Literatura, Cultura e Contemporaneidade.

Orientadora: Profa. Marília Rothier Cardoso 
Pontifícia Universidade C Católica

DO RIO DE JANEIRO

Rafael de Paula Taveira Rodriguez Meire

ESTILOS: ENTRE MACHADO E SEUS RECRIADORES

Dissertação apresentada como requisito parcial para obtenção do grau de Mestre pelo Programa de Pós-Graduação em Literatura, Cultura e Contemporaneidade do Departamento de Letras do Centro de Teologia e Ciências Humanas da PUC-Rio. Aprovada pela Comissão Examinadora abaixo assinada.

Profa. Marilia Rothier Cardoso

Orientadora

Departamento de Letras - PUC-Rio

Profa. Helena Franco Martins

Departamento de Letras - PUC-Rio

Prof. André Monteiro Guimarães Dias Pires

UFJF

Profa. Denise Berruezo Portinari

Coordenadora Setorial do Centro de Teologia

e Ciências Humanas - PUC-Rio

Rio de Janeiro, 05 de abril de 2013. 
Todos os direitos reservados. É proibida a reprodução total ou parcial do trabalho sem a autorização da universidade, do autor, e da orientadora.

\section{Rafael de Paula Taveira Rodriguez Meire}

Graduou-se em Letras pela Universidade Federal Fluminense (UFF), com habilitação em Português e Literaturas de Língua Portuguesa, em 2008. Especializou-se em Literatura, Arte e Pensamento Contemporâneo - administrado pela Coordenação Central de Extensão da PUC-Rio -, em nível de PósGraduação "Lato Sensu", em 2011. Concluiu com aprovação o curso de Mestrado em Literatura, Cultura e Contemporaneidade do programa de Pós-Graduação em Letras da Pontifícia Universidade Católica do Rio de Janeiro (PUC-Rio), em 2013. Atualmente, é doutorando em Letras pela mesma instituição.

Ficha Catalográfica

Meire, Rafael de Paula Taveira Rodriguez

Estilos: entre Machado e seus recriadores Rafael de Paula Taveira Rodriguez Meire ; orientador: Marília Rothier Cardoso. - 2013. 118 f. ; $30 \mathrm{~cm}$

Dissertação (mestrado)-Pontifícia Universidade Católica do Rio de Janeiro, Departamento de Letras, 2013.

Inclui bibliografia

1. Letras - Teses. 2. Estilo. 3. Escrita. 4. Corpo. 5. Trabalho. 6. Valor. 7. Perspectiva. 8. Assis, Machado de. 9. Literatura contemporânea. I. Cardoso, Marília Rothier. II. Pontifícia Universidade Católica do Rio de Janeiro. Departamento de Letras. III. Título. 


\section{Agradecimentos}

A Renata Maranhão.

Aos meus pais e à minha irmã Renata.

A Marília Rothier Cardoso.

Aos amigos do Mestrado.

A Thiago Assis.

A Bernardo Villela. 


\section{Resumo}

Meire, Rafael de Paula Taveira Rodriguez; Cardoso, Marília Rothier. Estilos: entre Machado e seus Recriadores. Rio de Janeiro, 2013. 118p. Dissertação de Mestrado - Departamento de Letras, Pontifícia Universidade Católica do Rio de Janeiro.

A partir do conto "O cônego ou metafísica do estilo", de Machado de Assis, a presente dissertação propõe um traçado teórico em torno dos conceitos de estilo e de escrita, investigando em que medida o primeiro, se pensado à luz de outra base epistemológica que não a tradicional, é absorvido pelo segundo. Para tanto, observa-se como os conceitos em questão se comportam no interior da obra de Roland Barthes em contraponto com algumas formulações conceituais de contemporâneos desse teórico. O recurso ao pensamento barthesiano tem como objetivo principal, no entanto, ressaltar a preocupação de Machado de Assis com a escrita; preocupação essa presente, enquanto dobra teórica, em suas narrativas espaço ficcional onde se pode rastrear o diálogo constante do romancista com a filosofia. Perseguindo essas referências fundamentais do fazer literário, passa-se, por fim, à discussão crítica da prática escritural à qual se lançaram alguns autores contemporâneos: recriar contos escolhidos do autor fluminense.

\section{Palavras-Chave}

Estilo; escrita; corpo; trabalho; valor; perspectiva; Machado de Assis; literatura contemporânea. 


\section{Abstract}

Meire, Rafael de Paula Taveira Rodriguez; Cardoso, Marília Rothier (Advisor). Styles: Between Machado and his Recreators. Rio de Janeiro, 2013. 118p. MSc. Dissertation - Departamento de Letras, Pontifícia Universidade Católica do Rio de Janeiro.

Drawing from the short story "The Priest or the Metaphysics of Style," by Machado de Assis, this dissertation proposes to follow a theoretical trajectory of concepts and styles of writing, investigating to what extent one, using this as another base of epistemology that's unorthodox, is absorbed by another. Such that we observe how the concepts in question operate in the work of Roland Barthes as counterpoint to some conceptual formulations of contemporaries in this school of thought. Meanwhile, Barthesian thought has as its principal tenet to reinvigorate the Machado de Assis' preoccupation with the act of writing; the preoccupation is present, folded into the writing, in his stories - there is a fictional space where he can explore the eternal debate between a novelist and philosopher. Following these fundamental references to the literary craft, in the end, a critical discussion occurs on the practice of writing, from which some contemporary writers were spawned: thus they began recreating tales of the Carioca author.

\section{Keywords}

Style; Writing; Body; Work; Value; Perspective; Machado de Assis; Contemporary Literature. 


\section{Sumário}

Considerações iniciais

1. Valor-corpo, valor-trabalho, valor-gênio

2. O estilo, um estilo

3. Escrita e escrevência

4. Dono do mundo

5. Rumo às Aparências

6. Dono da cidade, dono do mundo ou: Amor aos ossos

8. Referências bibliográficas 
Eu deixo-me estar entre o poeta e o sábio.

Machado de Assis 


\section{Considerações iniciais}

Em conferência da década de 1980, Silviano Santiago (1987) propõe-se discutir a questão - à época inusitada - da permanência do discurso da tradição no modernismo. Para tanto, faz uma distinção entre as noções de moderno e de modernismo, para que se evitem confusões em seu uso. Assim é que a primeira, mais abrangente e universal, diz respeito ao "movimento estético que é gerado dentro do Iluminismo"; ao passo que a segunda, menos abrangente e mais localizada, é referida como a "própria crítica do passadismo, concretizada na Semana de Arte Moderna de 22" (Santiago, 1987, p.114).

Em traços gerais, diga-se que uma de suas preocupações será buscar, no auge do modernismo, amostras de interesse pela tradição - como foi o caso, por exemplo, da obra de Murilo Mendes. Convidado a tratar do tema da tradição literária, Silviano Santiago, então, começa por se questionar sobre o porquê do retorno de tal questão justo naquele momento - os idos dos anos 1980 - em que os projetos moderno e modernista pareciam ter chegado ao seu esgotamento.

Assim sendo, o crítico traz para o debate formulações de Otávio Paz como "o ocaso das vanguardas" e "poética do agora", as quais marcariam o fim de uma era orientada, sobretudo, pela tradição da ruptura e apontariam para problemas ligados ao que se começou a chamar então de momento pós-moderno.

Contra a imposição do novo a qualquer custo e, em última análise, contra a arraigada valorização da originalidade do artista é que se levantarão as então chamadas "novíssimas gerações", investindo no uso do pastiche e explorando o seu potencial de suplementar, pela pluralidade e em direções imprevistas, a tradição cultural que lhes foi legada.

Endossar o passado, contudo, não significa repetir seus paradigmas. Para o crítico, há que se fazer a distinção entre repetição e suplemento, a partir da qual este último, além de não repetir inocentemente os paradigmas do passado, pode chegar, inclusive, a adquirir dimensões transgressoras.

Em meio a essas questões, pergunto-me sobre o lugar que ocupariam aquelas experiências literárias a que, grosso modo, podemos chamar de 
homenagens a determinado autor. No caso brasileiro, Machado de Assis é o primeiro nome, que ocorre, como objeto de resgate motivado por admiração diante de seu legado instigante.

Em se tratando de contos, tomei conhecimento, ao longo da pesquisa, de quatro coletâneas, todas elas compostas somente de recriações literárias de narrativas curtas do escritor fluminense. São elas: Missa do Galo: variações sobre o mesmo tema, projeto idealizado por Osman Lins no final da década de 1970; Um homem célebre: Machado recriado, proposta editorial da Publifolha reunindo dez autores; Capitu mandou flores; e, finalmente, Recontando Machado - essas duas últimas organizadas, respectivamente, por Rinaldo de Fernandes e Luiz Antonio Aguiar.

De saída, diga-se que: se tais experiências literárias não são concebidas segundo uma perspectiva de ruptura com a tradição (coisa que o próprio termo "homenagem" sugere), tampouco elas lançam mão do uso do pastiche tal e qual se refere Silviano.

Nesse sentido, os contos das coletâneas em questão possuem uma particularidade: se de um lado funcionam melhor se postos em relação aos de Machado - sem o que os efeitos por eles obtidos acabam enfraquecidos -, de outro lado seus autores vêem-se encerrados, por assim dizer, nos limites de sua própria assinatura (conto de Autran Dourado, conto de Tatiana Salem Levy, conto de Alberto Mussa, e assim por diante).

Em outras palavras: nenhum deles tentou narrar tal como um narrador machadiano / fazer pastiches do estilo de Machado de Assis. Quando muito, alguns optaram por escrever ao modo de algum narrador do século 19 (e não necessariamente ao modo de Machado) no que diz respeito às construções sintáticas ou à escolha do léxico.

Assim, mais do que se lançar em esforço classificatório, indagando em que medida essas experiências literárias poderiam ou não ser pensadas à luz da noção de ruptura com a tradição ou à luz do pastiche como suplemento, creio ser mais produtivo problematizar a construção estilística, ele mesma, como esfera complexa - tomando como referência contos escolhidos de Machado e (somente) aquelas "homenagens" que, afinadas com aspectos de sua escrita, possuem maior alcance crítico e teórico. 
Com isso, a discussão sobre o conceito de estilo, por sua vez, torna-se necessária: de um lado, o estilo pensado como esfera que aponta para o sujeito criador e suas particularidades, de outro lado, o estilo como esfera que aponta para a coletividade da linguagem e suas generalidades. E ainda: de um lado, o estilo pensado como conceito alicerçado na partição entre forma e conteúdo (ou expressão e pensamento), de outro lado, o estilo como conceito que recusaria tal partição, apresentando-se, para tanto, indissociável do pensamento. (Essa polarizações, é preciso dizer, concernem às orientações tradicionais, que problematizo ao tratar do assunto.)

Dizendo de outro modo: a noção de "estilo" com a qual a presente dissertação propõe-se trabalhar escapa à perspectiva desatualizada e/ou simplificadora com que alguns dos contos-homenagens das coletâneas em questão parecem ter trabalhado, sobretudo no que diz respeito ao modo de se tratar o problema do "tema" a ser reescrito.

Paradigmático a esse respeito é o ensaio "provocação do visitante" 1 , no qual Autran Dourado (2005) fala a Osman Lins da importância de se manter o estilo próprio, a originalidade do escritor:

\begin{abstract}
A sua ideia [proposta de Osman Lins]: variaria apenas o estilo, a maneira de cada um, além da total liberdade criadora (...). E ambos concordamos em que, por usar os mesmos temas, os mesmos motivos e situações que seus antecessores, um artista não deixa de ser ele mesmo, não perde a sua originalidade essencial, se ele a tem (Dourado, 2005, p.146-147).
\end{abstract}

De minha parte, penso que a proposta de se empreenderem, em literatura, "variações sobre o mesmo tema", está muito alicerçada na perspectiva da arte representativa, perspectiva essa que o presente trabalho pretende questionar/reverter ao apoiar-se na prática escritural de Machado.

O que vale dizer que, em certos casos (não são todos), ao recriarem contos machadianos, alguns dos autores passaram ao largo de problemas que precisariam ser levados em consideração, fazendo com que seus contos, ao buscarem recontar a mesma história de modos diferentes, resultassem em narrativas que, a meu ver,

\footnotetext{
${ }^{1}$ Publicado em As imaginações pecaminosas.
} 
em pouco ultrapassam o âmbito do exercício / variações sobre elementos do enredo.

Ao debater em sua tese de mestrado as relações entre o Machado crítico literário e o Machado ficcionista - em proveito da dimensão crítica de sua obra de ficção -, Raquel Peralva Martins de Oliveira (2011) mostra como o escritor, já no século XIX, desafiava, através de sua narrativa metaficcional, os pressupostos representacionais da estética realista então em voga, antecipando (pelo menos no contexto brasileiro) a discussão de instâncias que só viriam a ser problematizadas teoricamente no século XX. Cite-se um trecho da dissertação de Oliveira:

Em diversos textos, ele [Machado] dá mostras desta sua capacidade de influenciarse, de admirar um outro texto e convidá-lo a habitar o seu próprio discurso. Sem maiores preocupações de fidelidade em relação ao texto-inspiração, ele procura aproveitar o que melhor lhe convém, retirando o texto de sua posição primeira e forçando-o à 'resignificação' em um outro contexto (Oliveira, 2011, p.80).

Com efeito, a impressão que se tem é a de que a escrita de Machado tornase tanto mais uma assinatura singularizadora quanto mais se afasta das tendências miméticas de seu tempo, lançando-se ao jogo circular da apropriação, da paródia, do pastiche, da citação, das alusões, das associações inesperadas etc. Ou seja: lançando-se à lógica do suplemento que marca a fase considerada "madura" de sua obra.

Esses expedientes, embora não sejam, eles mesmos, o meu foco de trabalho, levam a consequências que a ele importam diretamente: trata-se da tendência ao fragmentário, ao aforístico, à dicção ao mesmo tempo econômica e ziguezagueante que apontam, principalmente, para tensões não resolvidas fazendo com que a escrita de Machado, muitas vezes, possua alcance epistemológico. Nos parágrafos iniciais de "O cônego ou metafísica do estilo" (um dos contos estudados), por exemplo, se pode ler: "Nesse dia - cuido que por volta de 2222 - o paradoxo despirá as asas para vestir a japona de uma verdade comum. (...) Até lá passarei por tonto, como se vai ver” (Assis, 2008, p. 528-529).

Como aponta Antoine Compagnon (2010), a palavra estilo tornou-se um tanto contaminada e imprecisa ao longo da História, uma vez que acumulara praticamente todas as acepções a ela atribuídas da antiga Retórica à Linguística 
dos anos 60. Além disso, por muito tempo o estilo sustentou-se, como dito acima, à custa das dualidades entre as marcas individuais e os índices coletivos da linguagem; entre o ornamento da forma e o fundo do conteúdo (princípio da sinonímia, segundo o qual a mesma coisa poderia ser dita de modos diferentes; em última análise, princípio no qual Autran Dourado se apóia no ensaio “provocação do visitante").

Buscar conferir nuance a essas fraturas, ao observarem-se os movimentos de idas e vindas das escritas em questão - assim como pensar a construção estilística como esfera complexa -, são, pois, motivações da presente dissertação.

Seria justa, afinal, a afirmação de Dourado de que "por usar os mesmos temas, os mesmos motivos e situações que seus antecessores, um artista não deixa de ser ele mesmo, não perde a sua originalidade essencial’? (Dourado, 2005, p. 146-147). Se Compagnon afirma que o conceito de estilo é problemático pelo acúmulo de concepções, Deleuze (2004) pondera que a palavra estilo, assim como a palavra charme, precisa ser substituída, por inadequada:

\begin{abstract}
Charme e estilo são termos inadequados, seria necessário encontrar outros, substituí-los. É que, simultaneamente, enquanto o charme dá à vida uma potência não pessoal, superior aos indivíduos, o estilo concede à escrita um fim que lhe é exterior, que extravasa o escrito. E trata-se do mesmo: a escrita não tem a sua finalidade em si própria, precisamente porque a vida não é algo pessoal (Deleuze, 2004, p.16).
\end{abstract}

Assim é que, partindo de perspectivas críticas contemporâneas que levam em conta outro olhar sobre o conceito em questão, busco lançar luzes sobre um tipo de escrita que, embora realizado com certa frequência (como dito acima, só de recriações de contos de Machado tenho notícia de quatro livros), parece ser pouco estudado - talvez por, no mais das vezes, ser fruto de propostas editoriais que se apresentam ao público leitor como livros de "homenagem".

Qual seria, afinal, a melhor maneira de se homenagear um autor em cuja obra a construção estilística apresenta-se inseparável do pensamento em ação chegando, como proposto acima, a atingir dimensões epistemológicas? E ainda: se por um lado o espaço da homenagem não se mostra, à primeira vista, como um espaço de transgressão, poderia ele, por outro lado, apresentar-se como espaço de experimentações mais ousadas? Valorizando, tanto quanto possível, o trânsito 
entre contos e gerações de escritores, é a partir desse campo que faço minhas indagações.

Minha proposta, pois, é prestar contribuições às três frentes básicas em que atua: a discussão sobre o conceito geral de estilo; a reflexão sobre a escrita machadiana, alguns de seus aspectos e operadores críticos; e a avaliação crítica de recriações literárias de alguns dos contos de Machado. Embora essas três frentes devam ser pensadas em conjunto, cada qual não deixa de receber contribuições teóricas pertinentes ao seu debate particular. Além disso, concorrem para que se pense a pertinência da linguagem literária que, enquanto complexo de perceptos e de afectos, configura-se como atividade intransitiva ao mesmo tempo em que, via efeitos sensíveis, produz pensamento.

Entre a crítica machadiana, é consenso que a partir de Memórias póstumas de Brás Cubas e Papeis avulsos Machado de Assis chega à fase considerada madura de sua obra. A despeito disso, a relação tensionada do autor com a arte mimética / representativa (que, no meu entender, contribui para que sua ficção, no seu próprio fazer, encontre pontos de afinidade com correntes de pensamento antidogmáticas) é menos estudada. Em sintonia com a parcela da fortuna crítica que valoriza esses aspectos, busco prestar minhas contribuições.

Raquel Peralva Martins de Oliveira (2011), ao estudar as relações entre a obra de crítica literária de Machado e sua obra de ficção - em proveito da dimensão eminentemente crítica desta última -, explora a relação problemática do escritor com a estética realista, expressa por ele mesmo em seus artigos (dentre os quais a crítica a $O$ primo Basílio, de Eça de Queirós, talvez seja a mais conhecida).

Seguindo caminho semelhante, Gustavo Bernardo Krause (2011), além de artigos, dedica um livro inteiro ao assunto. Trata-se de $O$ problema do realismo de Machado de Assis. Na contramão da fortuna crítica sobre o autor (que o considera não apenas realista como o maior escritor realista brasileiro), o crítico afirmará que Machado não pode ser classificado como realista sob nenhum ponto de vista. Dentro dessa perspectiva, faz uma observação pertinente à presente dissertação, 
ao pôr lado a lado, numa espécie de relação mútua, os conceitos de realismo e de ceticismo - referindo ambos à obra machadiana.

O realismo pretende descrever a realidade como ela é, enquanto o ceticismo não duvida que a realidade seja, mas duvida sempre de como o realista diz que ela é. Logo, se Machado de Assis é cético, não pode ser realista. Esta me parece uma conclusão filosófica absolutamente lógica (Bernardo, 2011, p.108).

Embora não desenvolva o tema do ceticismo no livro em questão, Krause é categórico ao considerá-la [a obra de Machado] incompatível com o realismo. E isso por um motivo: o cético seria, antes de tudo, um antidogmático; coisa que não se pode dizer do escritor realista, em sua pretensão de abarcar a verdade sobre a realidade via discurso literário / mimético.

Apesar de propor uma linha de raciocínio muito específica, a saber, o percurso progressivo de Machado rumo a uma perspectiva cética, José Raimundo Maia Neto (2007) defende algo nessa direção em $O$ ceticismo na obra de Machado de Assis, ao apostar na ideia de que, antes de tudo, o escritor lida com problemas epistemológicos em sua ficção. Por esse motivo, o filósofo considera redutoras as leituras que se esforçam por tomar sua literatura como representação exemplar da realidade social brasileira.

No seu entender, tal perspectiva cética está intimamente ligada à solução de ordem técnica que o escritor fluminense encontra para a forma literária, isto é, quando os narradores abandonam a terceira pessoa onisciente e adotam a primeira pessoa, tornando-se, ao mesmo tempo, autores de memórias. Brás Cubas, Dom Casmurro e Conselheiro Aires, assim, seriam todos personagens-escritores a observarem os movimentos, via personagem feminina, do que Maia Neto chama de vida exterior - espaço de agitações e de dúvidas ao qual o "homem de espírito" não consegue harmonizar-se plenamente. De modo que a zetesis (investigação), a epoche (suspensão do juízo) e a ataraxia (tranquilidade) - as três etapas do percurso cético - seriam percorridas cabalmente por esses narradorespersonagens.

No capítulo 5, veremos em que medida concordo e em que medida discordo dessa argumentação. Por ora, diga-se que me parece pertinente a ideia de pensar a 
forma literária como espaço privilegiado, embora não à maneira de José Raimundo Maia Neto.

Se Memórias póstumas de Brás Cubas é considerado um marco da fase madura de Machado de Assis no romance, Papeis avulsos o é no conto. O que leva a pensar que se poderiam vislumbrar em suas narrativas curtas os mesmos aspectos e/ou recursos que se vêem nos romances (ou ao menos uma semelhança entre eles, com ser o conto uma forma particularmente concisa de expressão, portanto desprovida do espaço discursivo de que dispõe o romance).

Como quer que seja, ao investir no trânsito entre contos escolhidos de Machado e suas "homenagens", minha atenção se voltará para a observação da "forma literária", ou seja, das nuances que concernem à construção estilística de cada texto no que eles têm de potência teórico-inventiva. Este ponto é fundamental, uma vez que será o modus operandi, por assim dizer, de minhas leituras. Neste particular, a noção de estilo é reconvocada e, ao se complexificar, amplia-se até se confundir com o conceito mesmo de escrita / escritura.

De fato, ao observar como os dois conceitos se comportam na obra de Roland Barthes, por exemplo, Leyla Perrone Moisés considera a questão do estilo (e sua relação com o conceito operatório de "escritura") um dos problemas mais espinhosos da teoria do crítico / escritor francês ${ }^{2}$.

Se Roland Barthes (1986) em O grau zero da escritura afirma que nem a língua em seu corte horizontal (social) nem o estilo em seu corte vertical (fisiológico, corporal) seriam produtos de uma escolha, Roberto Corrêa dos Santos (2011) apresenta esse tópico de maneira mais nuançada. Dessa maneira, ao lado da potência inconsciente e corporal, espécie de liberdade e cárcere ao mesmo tempo - "(t)ornar a brutalidade de ser o que se é uma força” (Santos, 1999, p.85) -, ele situa o elemento da "conquista"; isto é, do gesto repetido que, no em se fazendo do processo artístico, adquire consciência de si mesmo à medida que retoma, insistente e obsessivamente, os operadores críticos que animam o devir do fazer criativo.

Sob o crivo de um ethos, como nos diz Roberto Corrêa, Machado de Assis “cria sem cessar valores para avaliar valores" (Santos, 2011, p. 87. grifo meu). Tendo isso em vista, há que se pensar se essa criação não estaria inscrita no modo

\footnotetext{
${ }^{2}$ Devo essa informação à dissertação de mestrado de Raquel Peralva Martins de Oliveira, através da qual tomei conhecimento do assunto pela primeira vez.
} 
mesmo como ela se dá; ou seja, no próprio corpo da linguagem que, em interação dinâmica entre o dado material e o pensamento em ação, faz com que ambas as instâncias seja irredutíveis uma à outra.

Faço essas observações pelo seguinte motivo: partindo de "O cônego ou metafísica do estilo", pode-se perceber uma espécie de "teoria da escrita" que atravessa os enredos dos contos escolhidos; e diz respeito, salvo engano, a tópicos insistentes da ficção machadiana.

Dizendo de outro modo: ali onde Roland Barthes problematiza incessantemente a relação estilo-escrita, passando pelo elemento inconsciente e atingindo a potência salutar da "intransitividade", Machado de Assis, via fazer ficcional, também parece fazê-lo. E, ousando um pouco, eu diria até que há um esforço, no seu caso, de constranger a linguagem verbal em favor da potência desconstrutora do efeito sensível - o que pode ser percebido tanto na valorização (corporal) das superfícies e das aparências (a desierarquizar o lugar privilegiado da Ideia e das essências, às quais os juízos morais - verbais - são tributários), quanto na valorização, por exemplo, do elemento sonoro.

Embora alguns dos autores das coletâneas de homenagens a Machado tenham se proposto a reescrever trechos de romances, a sua maioria recriou contos; e contos, salvo um ou outro, pertencentes à chamada fase madura do autor fluminense.

Com o intuito de discutir as questões levantadas acima (que, no mais, dizem respeito à relação irredutível entre construção estilística e produção de pensamento), optei, contudo, por estudar somente dois contos-homenagens. Tratase de "Carta de uma mulher apaixonada", de Tatiana Salem Levy, e "De dentro do ovo para dentro da gaiola", de Marcelino Freire, recriações literárias de "Um esqueleto" e "Ideias de Canário", respectivamente.

Quando menos não fosse por uma questão de economia, essa decisão me pareceu pertinente pelo seguinte motivo: a despeito da qualidade que algumas das outras "homenagens" possuem (podendo ser aproveitadas, inclusive, para discutir outras questões), me parece que os contos de Tatiana Salem Levy e Marcelino 
Freire foram mais sensíveis a aspectos ligados à construção estilística que, em Machado, serve com rigor e sutileza aos questionamentos epistemológicos.

Assim é que, ultrapassando tanto a reverência ao autor canônico quanto a tentação de exercitar-se nos vãos e desvãos dos enredos, ambos dialogam de maneira mais profícua com os cortes e recortes que propus aqui. 


\section{1}

\section{Valor-corpo, valor-trabalho, valor-gênio}

Por ocasião de uma festa a se realizar em data próxima, o cônego honorário Matias recebe da parte dos festeiros um convite: compor um sermão para pregar o Evangelho no dia do evento. Titubeando entre aceitar ou não o encargo absorvido que estava pela leitura de uma "grande obra espiritual" -, o eclesiástico só se resolve pela primeira alternativa após ver pela manhã seu nome impresso nos jornais, selando o compromisso e anunciando a ele, Matias, como "um dos ornamentos do clero brasileiro" (Assis, 2008, p. 529). A expressão tira ao padre a vontade de almoçar. Só então é que ele se entrega à tarefa de escrever por encomenda.

De início com má vontade, passados alguns minutos Matias já trabalhava com amor, quando, de súbito, interrompe o fluxo contínuo e polido de suas frases: após escrever um substantivo (do qual o leitor não é informado ao longo do conto), o orador não consegue encontrar o adjetivo mais adequado - dir-se-ia: o único adjetivo possível - que lhe pudesse completar o sentido. No afã de procurálo, suspende a pena. Em torno desse motivo, será construído o plot da narrativa.

Deixando-se de lado, por ora, o que em tal busca pode haver de ataque bem humorado da parte do narrador ao preciosismo do cônego (ou à provável grandiloquência de sua retórica, ou ao dispêndio lingüístico da dicção românticoparnasiana em voga na época, ou mesmo - o que seria mais interessante - a todo um modo de se pensar o trabalho estilístico, segundo o qual este se configuraria, grosso modo, como mero agente de ornamentação discursiva); deixando-se de lado, por ora, tais considerações, ponhamos resumidamente o foco em três valores que, a meu ver, comparecem na procura da personagem pelo seu adjetivo ideal - e se encerram em questões teóricas relacionadas aos conceitos de estilo e de escrita: valor-corpo, valor-trabalho, e valor-gênio ${ }^{3}$.

\footnotetext{
3 "Valor-trabalho" e "valor-gênio": expressões cunhadas por Roland Barthes no ensaio "O artesanato do estilo", de O grau zero da escritura (1986). Vali-me das duas formulações barthesianas para cunhar a expressão análoga "valor-corpo".
} 
Publicado originalmente em 1885 na Gazeta de Notícias e posteriormente em 1895 na coletânea Várias Histórias, o conto de que ora me valho como lugar teórico, "O cônego ou metafísica do estilo", de Machado de Assis, lida frontalmente com esses três valores, embora a eles conferindo pesagens distintas.

No limite, diga-se que o valor-corpo comparece explicitamente em seu enredo (e é explorado à exaustão pelo narrador), ao passo que o valor-trabalho e o valor-gênio são apenas sugeridos - o que de modo algum os torna menos relevantes para o desfecho da história, como a tempo se verá. Retomemos esta última do ponto em que o eclesiástico interrompe a redação de seu sermão, pois que a essa interrupção seguir-se-á outra que nos abrirá todo um horizonte de análise.

No momento em que Matias suspende a pena, o narrador em terceira pessoa de "O cônego ou metafísica do estilo" também suspende seu fluxo narrativo, fazendo ao leitor uma proposta tão interessante quanto inverossímil - "subamos à cabeça do cônego" -, proposta essa que lhe dará [ao leitor] acesso ao que estou chamando aqui de valor-corpo: toda a atividade inconsciente que se dá nas conexões nervosas do cérebro do personagem-escritor. Ou seja, aquilo que no ato da escrita foge à consciência e, portanto, à interferência do controle pelo ordenamento da razão.

Façamos uma breve digressão, buscando explorar, via Giorgio Agamben (2007) e Roland Barthes (1986), em que medida a escrita se configura como um ato que, em parte, se dá de modo independente do empenho lúcido do escritor ao mesmo tempo em que o impele (ou, antes, o atrai) na direção de uma instância - a saber, a da linguagem - eminentemente impessoal e pré-individual.$$
* * *
$$

Em ensaio publicado no livro Profanações, Agamben pondera que

Escrevemos para nos tornarmos impessoais, para nos tornarmos geniais, e, contudo, escrevendo, identificamo-nos como autores desta ou daquela obra, distanciamo-nos de Genius, que nunca pode ter a forma de um Eu, e menos ainda a de um autor (Abamben, 2007, p. 18).
} 
Genius, deus ao qual, para os latinos, todo homem é confiado na hora do nascimento (e que, em traços gerais, corresponde à figura do anjo da guarda na ideia cristã), é, à primeira vista, o mais íntimo e pessoal dos deuses: tendo-se em vista que cada um de nós possui o seu próprio Genius (o seu "anjo" particular), as vontades deste são as nossas vontades; suas demandas, as nossas demandas. Não atendê-las, portanto, significa fraudar o próprio gênio; e fazê-lo é fraudar-nos a nós mesmos e à vida que nos gerou (segundo Agamben, a etimologia da palavra Genius é transparente: ainda hoje é possível perceber na língua italiana a aproximação entre os vocábulos "gênio" e "gerar").

De modo que "Genium suum defraudare - fraudar o próprio gênio significa, em latim, tornar triste a própria vida, ludibriar a si mesmo. E genialis genial - é a vida que distancia da morte o olhar e responde sem hesitação ao impulso do gênio que o gerou" (Agamben, 2007, p 16).

Mas este que [nos dirá o autor] num primeiro momento se apresenta como o mais íntimo e pessoal dos deuses, é só para, logo em seguida, revelar-se como aquilo que em nós há de mais impessoal, uma vez que nos supera e nos excede fazendo com que sejamos, ao mesmo tempo, "mais e menos do que nós mesmos (...): Genius é a nossa vida, enquanto não foi por nós originada, mas nos deu origem" (idem).

Para Agamben, compreender a concepção de homem implícita em Genius implica compreender que, antes de tudo, o homem é um ser bifásico: ao lado do "Eu e consciência" (para aproveitarmos a expressão exata do autor), há também um dado "impessoal e pré-individual" que o compõe e com o qual ele precisa saber lidar, não tanto como fatalidade, mas como (feliz) constatação, porque "é Genius que rompe com a pretensão do Eu de bastar-se a si mesmo" (Agamben, 2007, p. 17).

Assim é que conservar, respeitar e honrar tudo aquilo que foge ao nosso controle e racionalidade, - excedendo-nos, portanto, - são as atitudes que, para Agamben, nos unem aos expedientes das "coisas que estamos acostumados a considerar mais nobres e elevadas" (Idem), como, por exemplo, os caminhos da espiritualidade.

Nem só de espiritualidade, contudo, se faz Genius. Daí a frase sintética - e a meu ver um tanto feliz - do ensaio em questão: “Todo o impessoal em nós é genial" (Idem). 
Nessa perspectiva, genial é o sangue que corre pelas veias; o prazer que se sente quando se está cansadíssimo e o sono chega; a intimidade da vida fisiológica, "lá onde o mais próprio é o mais estranho e impessoal, o mais próximo é o mais remoto e indomável” (Idem). Em uma frase: genial é o corpo. Como lembra o filósofo italiano, fôssemos apenas 'Eu e consciência' e não seríamos capazes sequer de urinar.

De minha parte, ao pequeno rol de coisas geniais elencadas por Agamben, tomo a liberdade de acrescentar mais uma: genial é a cabeça do cônego Matias enquanto complexo maquínico cujos comandos e engrenagens o mesmo não é capaz de acionar a partir de seu "Eu e consciência".

Com efeito, ao subirmos à cabeça do padre, observamos que este (como enfim todas as pessoas) não possui qualquer domínio, em termos fisiológicos, sobre o que nela se passa. De sujeito, - afinal era Matias que procurava pelo adjetivo perdido, - ele passa quase que a simples joguete das forças autônomas de atração e repulsa operadas pela dinâmica da linguagem, esta última interiorizada pelos mecanismos mnemônicos de sua cabeça em "camadas de teologia, de filosofia, de liturgia, de geografia e de história, lições antigas, noções modernas, tudo à mistura, dogma e sintaxe (...)" (Assis, 2008, p. 531).

No jogo do enredo, essas forças de atração e repulsa põem-se em ação, sobretudo, através da estratégia ficcional levada a cabo pelo narrador: personificar a linguagem mediante a ideia de que palavras "têm sexo" e "amam-se umas às outras" - estratégia que, a meu ver, reforça a corporeidade dessas últimas, que seriam escolhidas e combinadas mais por seus efeitos sensíveis e estéticos que por seu significado:

Temos à escolha um ou outro dos hemisférios cerebrais; mas vamos por este, que é onde nascem os substantivos (...). Sim, meu senhor, os adjetivos nascem de um lado, e os substantivos de outro, e toda sorte de vocábulos está assim dividida por motivo da diferença sexual...

- Sexual?

Sim, minha senhora, sexual. As palavras têm sexo. Estou acabando a minha grande memória psico-lexico-lógica, em que exponho e demonstro esta descoberta. Palavra tem sexo.

- Mas, então, amam-se umas às outras?

Amam-se umas às outras. E casam-se. $\mathrm{O}$ casamento delas é o que chamamos estilo (Assis, 2008, p. 529). 
Acrescente-se que, por se tratar de um cérebro eclesiástico, substantivo e adjetivo (a certa altura apelidados de "Silvio" e de "Silvia") clamam um pelo outro se valendo da retórica do Cântico dos cânticos: "Vem do Líbano, esposa minha, vem do Líbano, vem..." (Assis, 2008, p. 528); o que não se daria, como aponta jocosamente o próprio narrador, caso se estivesse na cabeça de qualquer outra pessoa do século. Nesse caso, o tom seria o de Romeu: "Julieta é o sol... ergue-te, lindo sol" (Assis, 2008, p. 530).

Dizendo de outro modo: a prática escritural, tal como por ora a estamos abordando a partir da noção de valor-corpo, apresentaria duas instâncias que se imbricam de modo indiscernível entre si. De um lado, 1) tem-se a articulação inconsciente (fruto da atividade cerebral) do arquivo lingüístico extensivo de cada falante ${ }^{4}$, isto é, aquilo que, alheio a qualquer vontade, está inscrito no âmbito das pulsões corporais - para o qual concorre, em última análise, a estratégia ficcional de descrever a construção estilística como romance desdobrado na cabeça do personagem-escritor, condensando-se todo um vocabulário biológico e psicológico a metáforas romântico-sexuais. De outro lado, 2) tem-se o funcionamento coletivo, pré-individual e autônomo da língua, "objeto social por definição, não por eleição" (Barthes, 1986, p. 121), para falarmos com o Roland Barthes de $O$ grau zero da escritura.

Nesse ponto, façam-se algumas ressalvas. Assim como ligações que, por ora, interessam mais diretamente.

Ao falar sobre o elemento impessoal e pré-individual em "Genius", Agamben enfatiza, tanto quanto posso perceber, a importância do corpo entendido como instância potente o suficiente para abalar a supremacia daquilo a que denomina "Eu e consciência".

Nesse ínterim, mostra que o corpo - como a vida - só é nosso na medida mesmo em que não nos pertence, inserindo-o, com o feliz paradoxo, em todo um arco pré-individual(izante) que excede o homem - tal qual a tuberculose mencionada por Roland Barthes (2007) em Aula, quando este, relendo Thomas Mann, descobre estupefato que seu próprio corpo era histórico: “Ora, a

\footnotetext{
${ }^{4}$ No caso de "O cônego ou metafísica do estilo", ao lado das noções de liturgia, filosofia, história etc. que povoam a cabeça da personagem Matias, figuram também lembranças afetivas, memórias, reminiscências, anedotas e até regras de voltarete: tudo isso assimilado e, é escusado dizer, nomeado pelo código linguístico.
} 
tuberculose que eu vivi é, com mínimas diferenças, a tuberculose $\mathrm{d} A$ Montanha Mágica: os dois momentos se confundiam, igualmente afastados de meu próprio presente" (Barthes, 2007, p. 44).

Não será à toa, diga-se de passagem, que Agamben nos lembra que Genius não conhece o tempo... "abolição do tempo, epifania e presença de Genius" (Agamben, 2007, p.17).

De todo modo, pode-se dizer que, no curto espaço de seu ensaio, a ênfase do filósofo italiano ao discorrer sobre a face impessoal do homem repousa, sobretudo, sobre o conceito de corpo. Com isso quero dizer que em "Genius" ele não se propõe teorizar (ao menos de modo direcionado, detido) sobre o problema da linguagem enquanto instância igualmente impessoal e pré-individual. A despeito disso, as duas frases que dão início ao seu período certeiro "escrevemos para nos tornarmos impessoais, para nos tornarmos geniais (...)" (Abamben, 2007, p.18), por si só, não deixam de ser uma poderosa investida nesse sentido.

Como quer que seja, o fato é que, em 1953, esse aspecto eminentemente pré-individual da língua ${ }^{5}$ era uma questão importante (entre outras, naturalmente) que se impunha ao Roland Barthes de $O$ grau zero da escritura, quando este esboçava limites entre as noções de língua, estilo e escritura no ensaio "O que é a escritura?".

Para efeito do que nos interessa, entretanto, por ora basta-nos dizer que, no que concerne aos conceitos de "língua" e "escritura", esta última se apresentava como uma escolha possível, enquanto que aquela não passava de um horizonte, de uma "Natureza" (Barthes, 1986, p. 121) contra a qual o escritor pouco ou nada poderia. Esse estado de coisas - assim suponho - se deve ao fato de essa "Natureza" (tal qual, em última análise, as demandas fisiológicas do corpo) situarse na mesma zona impessoal e pré-individual em relação ao homem:

[A língua] (n)ão é o lugar de um engajamento social, mas somente um reflexo sem escolha, a propriedade indivisa dos homens e não dos escritores; ela permanece fora do ritual das Letras; é um objeto social por definição, não por eleição. Ninguém pode, sem preparação, inserir sua liberdade de escritor na opacidade da língua, porque através dela toda a História se mantém, completa e unida à maneira de uma Natureza. Assim, para o escritor, a língua é apenas um horizonte humano

\footnotetext{
${ }^{5}$ No registro/suporte específico em que estamos trabalhando (o verbal), "linguagem" e "língua" são conceitos próximos, posto que esta, seguindo as orientações de Barthes em Aula, é a "expressão obrigatória" (BARTHES, 2007, p. 12) daquela.
} 
que instala ao longe uma certa familiaridade, completamente negativa por sinal (Idem. grifo meu).

Dentro desse quadro, não espanta que a noção de estilo para o Roland Barthes de O Grau Zero - "imagens, um fluxo verbal, um léxico" (Barthes, 1986: 122) - também não se configurasse como uma escolha, mas sim como uma "Necessidade" (Barthes, 1986, p. 123).

Nascendo "do corpo e do passado do escritor" e tornando-se pouco a pouco "os próprios automatismos de sua arte" (Barthes, 1986, p. 122), me parece que o conceito de estilo, nessa primeira perspectiva barthesiana, além da forte vocação fisiológica possui também certa vocação histórica: o "passado" a que Barthes se refere - "lembrança encerrada no corpo do escritor" (Barthes, 1986, p. 123) -, visto de hoje, pode ser pensado de modo a se levar em conta não só seu aspecto privado/individual ${ }^{6}$, mas também - no encalço de Genius - o coletivo/préindividual.

Fechando a digressão e voltando a Machado de Assis, o que pretendo sublinhar é o fato de que não será o cônego Matias (ou só o cônego Matias) que encontrará o tal adjetivo que procura para seu substantivo. Como visto acima, estes dois é que, personificados pelo narrador, procurar-se-ão um pelo outro em seu inconsciente (ou, para ser mais exato, em sua não-consciência):

Ouvem-se cada vez mais perto. Eis aí chegam eles às profundas camadas de teologia, de filosofia (...), mas nada disso é Silvio e Silvia. Eles vão rasgando, elevados de uma força íntima, afinidade secreta, através de todos os obstáculos e por cima de todos os abismos. (...) Frases alegres, anedotas de sacristia (...), nada os retém, menos ainda os faz sorrir (...). Amam-se e procuram-se. Procuram-se e acham-se (Assis, 2008, p. 531. grifo meu).

\footnotetext{
${ }^{6} \mathrm{Na}$ fase de $O$ grau zero da escritura, o crítico francês ainda relacionava a vocação fisiológica, corporal do estilo à esfera individual/privada do escritor - orientação que seria revista, segundo Leyla Perrone-Moisés (1978) ao longo de seu percurso intelectual.
} 
Ao encontrarem-se os dois, o cônego Matias estremece e seu rosto se ilumina. Ele anexa, enfim, o adjetivo que procurava ao substantivo. O narrador, por sua vez, afirma que a partir de então Silvio e Silvia caminhariam um ao pé do outro no sermão que o orador levaria ao prelo. E tudo estaria resolvido, caso não acrescentasse ao desfecho da história uma perturbadora ressalva: "se ele coligir os seus escritos, o que não se sabe" 7 .

Ao que parece, Matias escrevia - ou logrou solucionar os impasses de sua escrita - graças à relação inconsciente/ não consciente com a cultura e/ou com a linguagem. E um grande ponto de interrogação é posto entre o leitor e as últimas linhas da narrativa, como se àquele fosse enfim perguntado: quando do choque entre o que na linguagem há de "força íntima, afinidade secreta" (Idem) e o que no corpo há de pulsão incontrolável, terá o valor-corpo, por si só, força suficiente para que o escritor dê conta de seus escritos? Ou só com ele, pelo contrário, os escritos é que dariam conta do escritor, este sem qualquer tipo de domínio sobre aqueles?

Em outras palavras: "sem preparação" (Barthes, 1986, p. 121), como propõe Barthes em $O$ Grau Zero, será que alguém pode com a língua? - uma vez que esta (para lembrarmos agora a famosa passagem de Aula, quase 25 anos depois) "não é reacionária, nem progressista; ela é simplesmente: fascista; pois o fascismo não é impedir de dizer, é obrigar a dizer" (Barthes, 2007, p. 14).

Para contrabalançar - lançando dúvidas - o lugar central que, a meu ver, o valor-corpo ocupa no conto em questão, eu diria que, neste, há duas ambiências às quais o leitor é submetido alternadamente, uma exterior e outra interior à cabeça de Matias.

De um lado, tem-se a casa em que a personagem vive para os lados da Gamboa, a janela onde vai espairecer e buscar inspiração, sua mesa de trabalho etc. De outro lado, tem-se o espaço virtual proposto pelo narrador, povoado de linguagem e em meio ao qual "Silvio" e "Silvia" se procuram alheios à lucidez do padre.

Da ambiência exterior, recorto uma imagem sugestiva: a mesa de trabalho. Para quem escreve, não será exagero dizer que, em maior ou menor grau, mesa seja sinônimo de trabalho. E trabalho, por sua vez, um valor com o qual, para falar

\footnotetext{
7 “(...) coligir os seus escritos”, aqui, no sentido de articular as partes do sermão, dando-o por pronto.
} 
ainda com Roland Barthes (1986), o escritor da modernidade teve de se haver para que pudesse fazer frente aos impasses a ele propostos pela cultura. Eis uma passagem de "O artesanato do estilo" de O grau zero da escritura:

\begin{abstract}
A escritura será salva não em virtude de sua destinação, mas graças ao trabalho que tiver custado. Começa então a elaborar-se [por volta de 1850] uma imagética do escritor-artesão que se fecha num lugar lendário, como um operário na oficina, e desbasta, talha, pole e engasta sua forma, exatamente como um lapidário extrai a arte da matéria, passando neste trabalho horas regulares de solidão e esforço (...). Esse valor-trabalho substitui de certa maneira o valorgênio; há uma certa vaidade em dizer que se trabalha bastante e longamente a forma (...) (Barthes, 1986, p. 152-153. grifo meu).
\end{abstract}

Embora Barthes estivesse se referindo a um contexto cultural bastante específico (o francês) e às transformações profundas que, segundo o autor, nele se operavam no momento histórico que gira em torno de 1850, o que me interessa, por ora, é o já mencionado valor-trabalho que está presente em sua primeira concepção de "escritura" 8 e, parcialmente, na de "estilo".

Abro um parêntese para explicar esse "parcialmente": se o valor-trabalho concerne ao conceito de escritura, - e esta, em o grau zero, é uma escolha consciente, - então não haveria valor-trabalho, supõe-se, nessa primeira concepção barthesiana sobre o estilo - uma vez que este último estaria ligado ao corpo. O título "O artesanato do estilo", contudo, por si só sugere o contrário. Discutirei esse tópico em outras partes da presente dissertação. Por ora, adianto que: 1) valor-trabalho se opõe a valor-uso ${ }^{9}$ na medida em que investe em um possível; e 2) valor-trabalho teria que ver com a noção de gesto repetido. Fecho parêntese.

Linhas acima afirmei que em "O cônego..." valor-corpo, valor-trabalho e valor-gênio estariam presentes, sendo que os dois últimos apenas de modo sugestivo, enquanto que o primeiro explorado à exaustão pelo narrador.

De fato, ao mostrar ao leitor como se dá a "metafísica do estilo", o narrador em momento algum lhe dá acesso ao que nela há de empenho lúcido, consciente:

\footnotetext{
${ }^{8}$ É fundamental salientar que a noção de "escritura" cunhada em O grau zero é de 1953, portanto de um Roland Barthes ainda em início de carreira. Como aponta Leyla Perrone-Moisés (1978), ela foi reformulada/ resignificada insistentemente ao longo de seu percurso intelectual.

${ }^{9}$ Tal qual o valor-gênio e o valor-trabalho, valor-uso é uma expressão barthesiana que se encontra em "O artesanato do estilo" (BARTHES, 1986, p.152).
} 
como vimos, a cabeça do cônego não passa de uma arena em que a linguagem põe em ação seus movimentos de idas e vindas. Na imagética do conto, o maior paradigma disso é a mesa de trabalho de Matias, que simplesmente evapora aos olhos do leitor em favor dos labirintos de sua cabeça, reaparecendo pouquíssimas vezes ao longo do conto.

Mas se o valor-trabalho é deslocado do plano da consciência para o da nãoconsciência, isso não quer dizer que o valor-gênio, também mencionado em "O artesanato do estilo", seja valorizado. Antes, diga-se que ele é contestado, ao contestar-se o que seria o momento de inspiração do padre junto a ninguém menos que a natureza:

\begin{abstract}
Agora não te assustes, leitor, não é nada; é o cônego que se levanta, vai à janela, e encosta-se a espairecer do esforço. Lá olha, lá esquece o sermão e o resto. O papagaio em cima do poleiro, ao pé da janela, repete-lhe as palavras do costume e, no terreiro, o pavão enfuna-se todo ao sol da manhã; o próprio sol, reconhecendo o cônego, manda-lhe um dos seus fiéis raios, a cumprimentá-lo. E o raio vem, e para diante da janela: 'cônego ilustre, aqui venho trazer os recados do sol, meu senhor e pai'. Toda a natureza parece assim bater palmas ao regresso daquele galé do espírito (Assis, 2008, p. 530. grifo meu).
\end{abstract}

Enquanto Matias espairece e inspira-se sob os influxos do sol, o senhor e o pai, substantivo e adjetivo "prosseguem em busca um do outro sem que ele saiba nem suspeite nada" (Idem).

Tal qual a mesa (imagem que relaciono ao valor-trabalho), a janela (imagem que relaciono ao valor-gênio) também evapora aos olhos do leitor, que continua a presenciar o substantivo e o adjetivo rompendo por conta própria camadas inconscientes de textualidades. Em outras palavras: quando o cônego retorna à mesa e encontra a palavra que procurava, sentindo um estremecimento e tendo a fronte iluminada como um medium que acabasse de receber influxos divinos, já se sabe que o encontro entre "Silvio" e "Silvia" está longe de ser fruto daquilo que o senso comum chamaria "inspiração", o valor-gênio.

A esse respeito, vale a pena voltarmos, ainda uma vez, a Agamben (2007), em passagem na qual o ensaísta menciona uma "ética das relações" que se pode ter com Genius (que, é importante frisar, nada tem a ver com esse gênio mediúnico): 
Há uma ética das relações com Genius que define a classe de cada ser. A classe mais baixa inclui aqueles que - e às vezes se trata de autores celebérrimos contam com o próprio gênio como se fosse um bruxo pessoal ('tudo me sai tão bem!'; 'se tu, gênio meu, não me abandonas...'). Muito mais amável e sóbrio é o gesto do poeta que, pelo contrário, menospreza esse sórdido cúmplice, porque sabe que 'a ausência de Deus nos ajuda!' (Abamben, 2007, p. 19).

Como visto, embora tenha encontrado a palavra perdida, não se sabe se o eclesiástico concluirá ou não a redação do seu sermão. Acaso faltaria mais trabalho (lucidez, direção) ao valor-corpo? Levando em consideração que o valorgênio, aparentemente, é desbaratado em favor de Genius, há que se propor nova questão: em que medida a noção de valor-trabalho, em se tratando de construção estilística, pode se configurar, em maior ou menor grau, como uma escolha, ou seja, como algo sobre o que o escritor possuísse algum domínio, ainda que precário?

Com essas questões, marco uma espécie de a priori teórico, para deixar claro o lugar de onde estou partindo: o sujeito de todo discurso, necessariamente, é um sujeito descentrado, rasurado pela linguagem e/ou pela cultura. O modo como este tem que se haver com estas - se de modo consciente e/ou nãoconsciente -, creio eu, dá as medidas, em certo sentido, de todo um percurso teórico que se pode fazer sobre as noções de estilo e de escrita, assim como de possíveis resignificações e contaminações mútuas entre esses dois conceitos.

Em outras palavras: para que se possa trabalhar com vetores não excludentes, como herança e conquista ${ }^{10}$, penso que valor-corpo e valor-trabalho (tomado, por ora, como atividade dirigida) devem ser, tanto quanto possível, solidários entre si. Talvez assim o escritor possa dar conta de seus escritos na mesma medida em que estes dão conta daquele.

Tendo em mente as noções brevemente esboçadas até aqui, proponho um traçado teórico em torno das noções de estilo, escrita e, lateralmente, de língua/linguagem.

\footnotetext{
${ }^{10}$ Noções de Roberto Corrêa dos Santos (1999).
} 


\section{2 \\ O estilo, um estilo}

Não se configurando como regras de composição, como queriam a retórica e a poética, e nem tampouco se apresentando como os desvios consentidos pela língua, como queria a estilística, o estilo estaria situado, segundo Roberto Corrêa dos Santos (1999), no âmbito das maquinarias (por ora, no sentido mecânico, de engrenagem mesmo): operações de repetição engendradas por uma espécie de força obsessiva.

Sem ser eminentemente histórico e social como a língua - horizonte negativo contra o qual o escritor nada pode e ao qual, de um modo ou de outro, precisa se reportar -, o estilo seria antes uma potência corporal: "Tornar a brutalidade de ser o que se é uma força" (Santos, 1999, p. 85).

Nesse ponto, faz-se necessária a seguinte ressalva: no capítulo anterior, valorizei justamente o aspecto coletivo, histórico do corpo - histórico no sentido que Roland Barthes deu à palavra em Aula, ao afirmar que sua tuberculose ultrapassava seu tempo e espaço presentes e ia ao encontro da do Tomas Mann $\mathrm{d} A$ Montanha Mágica. Na ocasião, fiz ligações entre o aspecto social/coletivo da linguagem, via Barthes, e o aspecto impessoal/ pré-individual do corpo, via Giorgio Agamben.

Desse modo, se no ensaio "Pensar escritores, Machado a exemplo" Roberto Corrêa em certa medida destaca a esfera privada do corpo e, por extensão, do estilo deste ou daquele escritor, relacionando-os às noções de força e brutalidade, isso não significa afirmar, de modo algum, que essa esfera privada seja sua única componente.

Muito pelo contrário, se nos limites do âmbito corporal privado a intransigência da força e da brutalidade se faz sentir, tal se dá justamente pelo fato de estas duas últimas ultrapassarem o "Eu e consciência" de cada pessoa, projetando-a, por sua vez, em direção àquela zona pré-individual (e, no mais, arredia ao controle) de que falava Agamben em "Genius". Daí a necessidade de se transformar em potência criativa o "ser o que se é" (Santos 1999, p. 85): não se 
podendo lutar contra este último, o melhor é a ele juntar-se - para usarmos a ideia geral de um dito corrente.

No ensaio de Roberto Corrêa, contudo, esse estatuto coletivo do corpo pode ser percebido quando o ensaísta relaciona as noções de estilo e memória. Tanto quanto percebo, esta não teria que ver apenas com a memória privada, entendida como arquivo ou complexo linguístico armazenado no cérebro de cada pessoa (à maneira do conto "O cônego..." de Machado), mas sim com uma memória algo atemporal ${ }^{11}$ - memória essa, portanto, que se encontraria alhures, suspensa no tempo (tal qual, mais uma vez, a tuberculose anterior ao nascimento de Roland Barthes, que se incorporou a sua vida):

Em seu caráter de aparelho (da existência concreta), [o estilo] recebe tudo como traço: armazena, processa, fornece informações, cria então seus múltiplos artefatos. A diversidade nasce do impulso sempre igual, da soberania e grandeza de ser este e não outro. Da alegria dura de tudo pôr e de tudo ter em superfície, do fato de constituir (e de articular-se a) uma memória, num certo sentido, fora do tempo (Santos, 1999, p. 85. grifo meu).

Feita essa ressalva, sigo ao ponto que mais diretamente me interessa. Dizer que o estilo é uma espécie de aparelho/aparato que armazena e produz, processa e fornece, é algo interessante, pois confere a ele certa força ativa, produtora. Mais interessante, contudo, é referir tal ideia ao âmbito da "existência concreta" (Idem); o que, a meu ver, é apenas outra maneira de se dizer que os problemas ligados ao conceito de estilo não se referem, necessariamente, a Retórica, Poética ou Estilística, ou seja, a problemas lingüísticos, mas sim a questões vitais. “O estilo, num grande escritor, é sempre também um estilo de vida (...), a invenção de uma possibilidade de vida, de um modo de existência" (Deleuze, 1992, p. 130), diria Deleuze (1992) em “A vida como obra de arte”, entrevista sobre Michel Foucault 12

Com efeito, do ponto de vista das avaliações tradicionais, as dúvidas básicas ligadas ao conceito em questão sempre foram tratadas, grosso modo, a partir do enfoque linguiístico, sem que, contudo, fossem problematizadas seja a linguagem

\footnotetext{
${ }^{11}$ Assim como o acervo da língua, essa noção de memória atemporal (e impessoal) corresponderia a uma soma virtual das memórias privadas.

${ }_{12}$ Publicada a 23 de agosto de 1986 em Le Nouvel Observateur e, posteriormente, em Conversações.
} 
propriamente dita (em geral pensada como instrumento estável) sejam as relações que o escritor trava com ela nas lides do processo escritural.

Se há um princípio que exemplifica de modo exemplar esse (pretenso) valor estável e instrumental da linguagem, ao menos nas discussões sobre o problema do estilo, esse princípio é o da sinonímia, segundo o qual a mesma coisa poderia ser dita de modos diferentes - legitimando-se, desse modo, a arraigada partição entre forma e conteúdo; e, por extensão, o caráter ornamental do trabalho estilístico:

\begin{abstract}
A noção tradicional de estilo pressupõe a noção de sinonímia. Para que haja estilo, é preciso que haja várias maneiras de dizer a mesma coisa: é este o princípio (...). Poder-se-ia manter a distinção entre o assunto - o que se diz - e o estilo - como se diz - sem se cair nas armadilhas do dualismo? (Compagnon, 2008, p. 185).
\end{abstract}

Segundo Antoine Compagnon (2008), da antiga retórica à estilística do século XIX e desta à linguística dos anos 1960, o conceito tradicional de estilo sempre se sustentara à custa de dualidades excludentes. Assim, no correr do amplo arco temporal que compreende a história do pensamento a seu respeito, ora o conceito foi pensado como instância que concernia ao sujeito e suas particularidades (caso da estilística), ora à linguagem e suas generalidades (caso da retórica clássica e da linguística); ora como sendo solidário ao princípio da sinonímia (caso da estilística e da retórica clássica), ora como sendo avesso a este último (caso da linguística).

Como quer que seja, fosse qual fosse a orientação teórica em questão, o fato é que sempre se esteve ou de um lado ou de outro, ou muito ao norte, ou demasiado ao sul. No limite, observe-se que a própria validade/existência do conceito, tradicionalmente falando, não foge às malhas do tudo ou nada: "por um lado, o estilo é uma certeza que pertence legitimamente às ideias pré-concebidas sobre a literatura (...); por outro, o estilo é uma ilusão da qual, como a intenção, como a referência, é imperioso libertar-se" (Compagnon, 2008, p. 163. grifo meu).

Se temos em mente que a linguagem é "profundamente trabalhada pelos dualismos, as dicotomias, as divisões por 2, os cálculos binários” (Deleuze, 2004, p. 46), como aponta Claire Parnet nos Diálogos com Gilles Deleuze, esses 
binarismos não chegam a espantar. Pelo contrário, tornam-se até mesmo compreensíveis.

Embora introdutório e panorâmico, o ensaio "O estilo", de Antoine Compagnon, paradoxalmente é um texto de erudição. Ao que parece, dirige-se tanto ao leitor diletante como ao leitor especializado mas iniciante no assunto. Assim sendo, não me demorarei em suas minúcias, embora a algumas delas possa me reportar, aqui e ali, para lançar mão desta ou daquela informação, deste ou daquele aspecto.

Por ora, limito-me a destacar o essencial: tendo em mente o par de dualidades mencionados acima, - 1) estilo como traço individual (idioleto) $\mathrm{X}$ estilo como traço coletivo (socioleto) e 2) estilo como solidário ao princípio da sinonímia $\mathrm{X}$ estilo como hostil a tal princípio, - diga-se que:

- Na retórica clássica, segundo Compagnon, haveria três tipos de "estilos" dentro dos quais o artista/poeta/enunciador poderia situar seu discurso: o stilus humilis (simples), o stilus mediocris (moderado), e o stilus gravis (elevado ou sublime). Diz-nos o crítico francês: "o estilo é propriedade do discurso; ele tem, pois, a objetividade de um código de expressão. Se ele se particulariza, é que ele é mais ou menos (bem) adaptado, convém mais ou menos à questão" (Compagnon, 2008, p.167). Em outras palavras: na antiga retórica, a noção de estilo próprio não existia. De modo que o poeta deveria situar seus escritos no âmbito de um dos três ethos então disponíveis - o vulgar, o moderado, ou o elevado. No que toca ao princípio da sinonímia, este não só se fazia presente (era necessário que se escolhesse uma das três formas possíveis para o tratamento deste ou daquele assunto) como seria um princípio teorizado/legitimado precisamente neste período:

(...) o estilo, pelo menos desde Aristóteles, se entende como um ornamento formal, definido pelo desvio em relação ao uso neutro ou normal da linguagem. Algumas oposições binárias bem conhecidas decorrem da noção de estilo assim compreendida: são 'fundo e forma', 'conteúdo e expressão', 'matéria e maneira' (Compagnon, 2008, p.166. grifo meu). 
A esse respeito, faço uma observação lateral (embora não gratuita no contexto da presente dissertação, uma vez que, mais à frente, tratarei de aspectos da "escrita cética" de Machado de Assis): Antoine Compagnon nos mostra que a tripartição da retórica clássica, chamada de rota Virgilii ["roda de Virgílio"] chegou a durar mais de 1000 anos, tendo sida transgredida somente no século XVI justamente por um atualizador do ceticismo filosófico de Pirro ${ }^{13}$, a saber, Michel de Montaigne:

Ela [a rota Virgilii] corresponde a uma hierarquia (familiar, média, nobre) que engloba o fundo, a expressão e a composição. Montaigne vai transgredi-la deliberadamente escrevendo sobre assuntos 'medíocres' e eventualmente 'sublimes' no estilo 'cômico e privado' das letras e da conversação (Compagnon, 2008, p. 167).

- A partir do século XVII, pouco a pouco a noção geral de estilo passa a associar-se à de indivíduo. De onde a ambiguidade nascente do conceito, que passa a ser descrito, a um tempo, como objetivo (na qualidade de código de expressão) e subjetivo (como reflexo de uma singularidade). Assim é que, segundo Compagnon, a concepção moderna de estilo (herdada do romantismo) associar-se-ia mais à noção de gênio (de nossa parte, poderíamos dizer: de valorgênio) que à de gênero. Escusado dizer que seria essa concepção, naturalmente, que a estilística do século XIX herdaria após a "morte" da retórica: esvaziada a lógica coletivizante do conceito, ascende em seu lugar a lógica individualizante.

Quanto ao princípio da sinonímia na estilística, acrescente-se que este se conserva intacto no sentido de manter a partição entre pensamento e expressão, só que agora deslocado do "repertório" coletivo e normativo dos três ethos para o âmbito individual (no limite, o artista os inventaria) dos desvios mínimos consentidos pela língua:

${ }^{13}$ Cf. José Raimundo Maia Neto: "Erasmo, Montaigne e Pascal são figuras centrais no renascimento do ceticismo grego na modernidade (...). Montaigne é o mais influente cético do período. Em seu ensaio 'Apologia de Raymond Sebond' retoma os temas principais de Sexto Empírico (...), e ajusta o pirronismo à Contra-Reforma" (MAIA NETO, 2007: 20-21). 
(...) a noção de estilo reapareceu nos estudos literários no sentido de detalhe sintomático, sobretudo em Leo Spitzer, cujos estudos de estilo procuram sempre descrever a rede de desvios ínfimos que permitem caracterizar a visão de mundo de um indivíduo, assim como a marca que ele deixou no espírito coletivo (Compagnon, 2008, p. 169. grifo meu).

- De modo que: se da antiga retórica à estilística do século XIX houve oscilações, de um extremo a outro, quanto à dualidade entre os planos coletivo e individual, o mesmo não se pode afirmar sobre o princípio da sinonímia. A rigor, este só seria questionado nos anos 1960 com a ascensão da linguística - que recusaria a partição entre pensamento e expressão através da postulação geral (hoje discutível, ao menos nos termos dogmáticos em que era proposta na época) de que seria impossível se pensar qualquer coisa fora da linguagem. Trocando em miúdos, o ato de pensar, por si só, já se daria de modo concomitante ao processo mental de formalização via linguagem.

A título de ilustração, cite-se uma passagem de um artigo importante ${ }^{14}$, segundo Compagnon, de Émile Benveniste: “(...) a forma linguística é, pois, não somente a condição de transmissibilidade, mas, em primeiro lugar, a condição de realização do pensamento. Nós só conhecemos o pensamento quando já enquadrado na linguagem" (apud. Compagnon, 2008, p. 177). Dentro de tal perspectiva, assim, variações estilísticas não passariam de diferenças semânticas: a rigor, dizer algo de outra maneira já seria dizer outra coisa.

Curiosamente, a partir do momento em que Compagnon chega à linguística dos anos 1960 (pelo menos no ensaio em questão) ele deixa de tecer considerações sobre o problema do sujeito que, como vimos, é tradicionalmente pertinente para o pensamento sobre o conceito de estilo.

Desse modo, o crítico e teórico francês volta sua atenção principalmente para a questão da sinonímia, no encalço de teóricos de datas mais recentes (como Nelson Goodman e Gérard Genette) que propõem soluções, além de, a meu ver, bastante conciliatórias, pouco úteis para a proposta da presente dissertação - que é pensar o conceito de estilo à luz de outras bases epistemológicas.

\footnotetext{
14 “Catégories de Pensée et Catégories de Language", de 1958.
} 
É que essas soluções conciliatórias - se não estou sendo injusto - parecem muito comprometidas, senão com o problema milenar da forma e do fundo, certamente com uma determinada concepção sobre a linguagem; concepção essa que, grosso modo, aceita, sem grandes problemas, seu caráter instrumental/comunicativo.

É nesse sentido que afirmei páginas acima que, em meio às suas questões de base, as teorizações tradicionais sobre o conceito de estilo não problematizam o mais importante: o estatuto da linguagem propriamente dita, em geral pensada como instrumento estável cujo valor-uso seria uma espécie de moeda de troca. Para efeito do que estou dizendo, deixo como derradeira ilustração a seguinte passagem/conclusão/autocrítica de Antoine Compagnon:

\begin{abstract}
Assim, ao princípio absolutista que condenava o estilo (há várias maneiras de se dizer a mesma coisa), pode-se substituir um princípio flexível que resgata a estilística (há maneiras bem diversas de se dizer coisas muito semelhantes e, inversamente, maneiras muito semelhantes de se dizer coisas muito diversas). No entanto, isso não seria, através de um desvio um tanto hipócrita, recair na estilística tradicional (...)? Provavelmente. Mas, o detalhe está neste 'mais ou menos' que torna a noção de estilo independente de um dualismo estrito: pensamento e linguagem (Compagnon, 2008, p.190. grifo meu).
\end{abstract}

Será? Como quer que seja, não me sinto animado, ao menos nos limites deste trabalho, a buscar respostas para tais questões. É chegado o momento em que é preciso escolher outras palavras, ao invés de palavras semelhantes para designar (ainda que mais ou menos) a mesma coisa. Não será à toa, certamente, que Deleuze proporá nos Diálogos com Claire Parnet:

Uma palavra é sempre substituível por outra. Se alguma não vos agrada, não vos convém, agarrem noutra, ponham outra em seu lugar. Se toda a gente fizer esse esforço, podemos compreender-nos, e já não há razão para pôr questões nem levantar objeções. Não há palavras certas. Também não há metáforas (todas as metáforas são palavras sujas, ou a sua causa). Só há palavras inexatas para designar exactamente alguma coisa (Deleuze, 2004, p. 13).

Gilles Deleuze não acreditava em metáforas; é improvável, portanto, que com sinônimos fosse diferente: no limite, ambos pressupõem um fundo/conteúdo estável sobre o qual deslizaria a expressão, a "forma". Daí a proposta: “Criemos 
palavras extraordinárias, mas na condição de as utilizarmos de modo vulgar" (Idem).

Ou seja, ali onde a "língua literária" difere da "língua de todos os dias" (Compagnon, 2008, p.163), Deleuze vê um devir: para além das [ou bem colados às] palavras, frases, ritmos ou figuras, há possíveis ${ }^{15}$. Esses possíveis, - tomo a liberdade de fazer uma aproximação, - seriam modos de vida: "Os devires são o que há de mais imperceptível. São actos que só podem estar contidos numa vida e expressos num estilo. Os estilos, como os modos de vida, não são construções" (Deleuze, 2004, p. 13. grifo meu). Leia-se: não são simplesmente problemas linguísticos, embora sejam, paradoxalmente, problemas de linguagem.

Em entrevista sobre Roland Barthes publicada originalmente no jornal $O$ escritor e, posteriormente, em Metalinguagem e outras metas, Haroldo de Campos (2006) sublinha a linha Flaubert-Mallarmé traçada por Barthes em $O$ grau zero da escritura; linha essa que desenharia o "processo de emancipação da linguagem na literatura da Modernidade" (Campos, 2006, p. 121). De um modo geral, esse processo configurar-se-ia, para usarmos as palavras do crítico paulista, como aquele em que a escrita (ou "escritura") se destituiria de sua "função instrumental" para "adquirir espessura enquanto objeto sígnico, enquanto linguagem voltada sobre si mesma" (Campos, 2006, p. 120-121).

É certo que toda orientação/militância crítica marca um lugar. E Haroldo de Campos, na qualidade de poeta, tradutor e crítico literário afinadíssimo com as orientações estéticas e teóricas das vanguardas históricas, naturalmente marca o seu ao atrair o roteiro Flaubert-Mallarmé (que, segundo ele, se desenvolvera "ao longo do século XIX até aos nossos dias ${ }^{16}$...”) para a constelação de referências teórico-crítico-inventivas da poesia concreta (Idem).

Não é sem alguma malícia, portanto, que faço menção à referida entrevista. Dos aspectos valorizados por Haroldo de Campos, a saber, o "novo" em literatura e sua crescente "espessura enquanto objeto sígnico", me interessa particularmente

\footnotetext{
${ }^{15}$ Uso a palavra, como se verá adiante, no sentido em que ela aparece em $O$ grau zero da escritura.

${ }^{16}$ A referida entrevista data dos anos 1980, de modo que os "nossos dias" já possuem trinta anos.
} 
o segundo: não tanto por sua vocação à formalização levada às últimas consequências, - coisa que, em certo sentido, fez a poesia concreta, - mas por sua vocação à intransitividade, ou seja, à relativização/redução sensível da função instrumental da linguagem e/ou da expressão literária.

Dessa função eminentemente instrumental, diz-nos Roland Barthes (1986) no ensaio a meu ver seminal "Triunfo e ruptura da escritura burguesa":

A diversidade dos 'gêneros' e o movimento dos estilos dentro do dogma clássico são dados estéticos, não de estrutura; nenhum dos dois devem iludir-nos: foi de uma escritura única, ao mesmo tempo instrumental e ornamental, que a sociedade francesa dispôs durante todo o tempo em que a ideologia burguesa triunfou (...). Sem dúvida, os escritores clássicos também conheceram uma problemática da forma, mas o debate não dizia respeito à variedade e ao sentido das escrituras (...), só estava em causa a retórica, isto é, a ordem do discurso pensado segundo uma finalidade de persuasão (Barthes, 1986, p. 148. grifo meu).

Antes de mais nada, é preciso reforçar que o percurso que Barthes faz, no ensaio em questão, das relações entre linguagem e momentos de ruptura bem definidos compreende, a rigor, o contexto político-cultural francês - contexto esse sobre o qual não possuo o domínio necessário. Como minha intenção, contudo, é aproveitar os aspectos e direções gerais do conceito nascente de "escritura" em $O$ Grau zero, creio que as próprias indicações do texto são mais que suficientes.

Neste, três momentos bem definidos são destacados: o momento préclássico da literatura francesa, que compreende os séculos XVI e início do XVII, quando "a língua parece ainda ensaiar estruturas instáveis e não fixou definitivamente o espírito de sua sintaxe e as leis de aumento de seu vocabulário" (Barthes, 1986, p. 147); o momento da escritura clássica, por volta de 1650, quando "os gramáticos clássicos livraram os franceses de qualquer problema linguístico, e essa língua depurada tornou-se uma escritura, isto é, um valor de linguagem dado imediatamente como universal (...)" (Barthes, 1986, p. 148); e, finalmente, o momento de ruptura que se dá por volta de 1850, quando as escrituras modernas - que são as que nos interessam - se multiplicam, impulsionadas pela perda da medida do universal que a burguesia carregava consigo desde o século XVII: 
É porque a pré-burguesia dos tempos monárquicos e a burguesia dos tempos pósrevolucionários, usando a mesma escritura, desenvolveram uma mitologia essencialista do homem, que a escritura clássica, una e universal, abandonou qualquer tremor em favor de um contínuo do qual cada parcela era escolha, vale dizer, eliminação radical de qualquer possível da linguagem. A autoridade política, o dogmatismo do Espírito e a unidade de linguagem clássica são, portanto, as figuras de um mesmo período histórico (Barthes, 1986, p.149. grifo meu).

A nós, importa atentar para o seguinte aspecto do delicado (e nuançado) pensamento de Roland Barthes: enquanto não se tem uma língua bem formada, constituída nacionalmente de modo homogeneizante (caso do momento "préclássico" aludido por Barthes que compreende os séculos XVI e início do XVII momento esse, salvo engano, que Michel Foucault trata no ensaio "A prosa do mundo" de As palavras e as coisas); pois enquanto não existe a língua constituída enquanto "Natureza", "horizonte negativo", não existe uma moral da linguagem e, portanto, uma escritura:

(...) enquanto a língua hesite quanto à sua própria estrutura, uma moral da linguagem é impossível; a escritura só aparece no momento em que a língua, constituída nacionalmente, torna-se uma espécie de negatividade, um horizonte que separa o que é proibido do que é permitido, sem se interrogar mais acerca das origens ou das justificações desse tabu (Barthes, 1986, p. 148).

O termo "escritura", desse modo, por si só não denota aquela intransitividade de que falávamos acima: o melhor exemplo disso, no contexto que estamos tratando, é o exemplo da escritura clássica francesa, que Roland Barthes associa ao triunfo da ideologia burguesa por volta de 1650. Esta, como mostra o crítico francês, é eminentemente instrumental: configurando-se como uma escrita de classe, formada em torno do poder, revestida dos "caracteres do universal" (Barthes, 1986, p. 149) e respaldada na retórica em sua vocação fundamental à persuasão, essa escrita, como não poderia deixar de ser, tem na clareza um valor imprescindível: 
$\mathrm{Na}$ verdade, a clareza é um atributo meramente retórico, não uma qualidade geral da linguagem, possível em todos os tempos e em todos os lugares, mas somente $o$ apêndice ideal de um certo discurso, justamente aquele submetido a uma intenção permanente de persuasão (Idem. grifo meu).

Nesse sentido, não apenas ela [essa escritura clássica francesa] está longe de ser intransitiva como é transitiva até seu último aspecto. Clareza e transitividade, é preciso dizer, são as duas faces de uma mesma moeda ${ }^{17}$.

Como já mencionado, somente por volta de 1850, quando a ideologia burguesa perde a medida do universal, abalada pela "ruína definitiva das ilusões do liberalismo" (Barthes, 1986, p. 150), é que se dá a ruptura impulsionadora das escritas modernas e o início do arco (ao qual se filia, por afinidade e eleição, Haroldo de Campos) que vai de Flaubert a Mallarmé: espécie de marco zero da noção de "escritura" pensada em sua função não instrumental e não transitiva.

Escrever, a partir desse estado de coisas, passa a ser: ir à caça de um possível, possível esse que esteve interditado, como sugere Barthes, ao longo dos mais ou menos 200 anos de escritura clássica - por esta se inscrever, enfim, no arco feliz e perene (no mau sentido) de uma língua maior, para falarmos em termos deleuzianos.

Em suma: embora não haja escritura sem o horizonte negativo de uma língua (pelo menos segundo as orientações de Barthes), há que se frisar que só há escritura no sentido não instrumental da palavra quando a relação com os pressupostos da língua encontra-se tensionada de modo contundente. Nesse sentido, a própria clareza, entre outros, pode ser um valor a ser problematizado.

Penso que muito da noção de valor-trabalho encontradiça no ensaio de Barthes (1986) "O artesanato do estilo" passe por aí. Explico-me. Não se trata, agora, de pensar a ideia de "trabalho" como atividade predominantemente racional, consciente, dirigida, que se oporia ao romântico (e superado) valorgênio.

Aliás, como ficou sugerido no capítulo anterior via leitura de "O cônego ou metafísica do estilo", de Machado de Assis, enquanto se escreve, mesmo que com

\footnotetext{
${ }^{17}$ Há textos de Barthes (já no Grau zero da escritura) que tratam da literatura engajada, pósrevolucionária. Nestes, o crítico francês ressalta o mesmo aspecto transitivo da linguagem - de onde a indiferenciação, em trecho citado acima, quanto ao modo de expressão entre as literaturas pré e pós Revolução Francesa: ambas situar-se-iam no mesmo âmbito persuasivo. Ambas possuiriam a "mesma escritura" (op. cit.).
} 
intenções dirigidas, todo um aparato inconsciente entra em ação no processo escritural. Trabalho e corpo, nesse sentido, são valores que se misturam. As consequências disso tivemos a oportunidade de observar: o escritor entra em contato com forças que o ultrapassam, assim como à sua vontade, ao seu controle pelo ordenamento da razão etc.

No sentido que ora tenho em mente, portanto, valor-trabalho seria algo a mais: seria tentar traçar um possível na linguagem mediante operações tensionadas, deslocamentos, embates com uma língua maior e seu poder de coerção, persuasão, pretensão à neutralidade etc.

Nesse sentido, mais que ao valor-gênio, o valor-trabalho se oporia ao já mencionado valor-uso: espécie de processo de torção/estilização daquilo que, na linguagem (e, mais especificamente, na língua), é tido como ponto pacífico. Paradigmáticas a esse respeito são essas duas passagens de Roland Barthes (das quais, paradoxalmente, faço uso instrumental para encerrar a presente seção em grande "estilo"): a primeira se encontra em "O artesanato do estilo", e a segunda em “O que é a escritura?" - ambas de $O$ grau zero.

\begin{abstract}
Ora, vimos que por volta de 1850 começa a surgir para a Literatura um problema de justificação: a escritura vai procurar álibis para si; e justamente porque começa a aparecer uma sombra de dúvida quanto ao seu uso, uma classe inteira de escritores preocupados em assumir a fundo a responsabilidade da tradição, vai substituir o valor-uso da escritura por um valor-trabalho. A escritura será salva não em virtude de sua destinação, mas graças ao trabalho que tiver custado (Barthes, 1986, p.152. grifo meu).
\end{abstract}

Desse modo, a escritura é uma realidade ambígua: de um lado, nasce incontestavelmente de uma confrontação do escritor com a sociedade; de outro lado, (...) ela remete o escritor, dessa finalidade social, para as fontes instrumentais de sua criação. Por não poder fornecer-lhe uma linguagem livremente consumida, a História lhe propõe a exigência de uma linguagem livremente produzida (Barthes, 1986, p. 125. grifo meu).

Feito esse percurso, chego ao ponto em que é preciso colocar as seguintes questões: em que medida, para os encaminhamentos da presente dissertação, ainda é válido fazer indagações sobre o conceito de estilo de modo generalizante: o estilo? Tendo em vista nossa própria demanda por outros olhares, não seria o caso 
de trocarmos o artigo definido pelo indefinido, sugerindo, com isso, recortes parciais ali onde havia grandes quadros - um estilo ${ }^{18}$ ?

Antoine Compagnon, ao discorrer sobre o conceito a partir de perspectivas tradicionais, em certo sentido aposta no artigo definido no título de seu ensaio. E traçando um quadro das vicissitudes do conceito ao longo do tempo, discorrendo sobre seus problemas e sutilezas, e propondo, por fim, soluções menos excludentes que as da retórica, estilística e lingüística, termina por deixar seu leitor, quer queira quer não, ao sabor daquela desconcertante questão - que tomo a liberdade de relembrar parafraseando: será o estilo uma realidade na qual se pode acreditar ou, pelo contrário, uma ilusão da qual é preciso livrar-se?

Realidade ou ilusão, creio que o debate, se tratado a partir do enfoque tradicional/linguístico, esteja francamente esgotado ou em vias de se esgotar; a não ser que se invista nos meios-termos a que, como indica o crítico francês, alguns teóricos chegaram quanto ao princípio da sinonímia: "Mas, o detalhe está neste 'mais ou menos' que torna a noção de estilo independente de um dualismo estrito" (Compagnon, 2008, p. 190).

Tendo isso em vista, o fato é que a emergência de outras orientações teóricas faz-se necessária. Nestas, não só os dualismos encontrar-se-iam problematizados, como também a escrita, o sujeito e, sobretudo, as relações entre estes dois.

De agora em diante, portanto, não tratarei o conceito de estilo de maneira generalizante, mas sim particularizada: meu esforço será o de pensá-lo a partir do campo de problema aberto por Roland Barthes (1986) em torno do conceito de escrita - campo esse, naturalmente, aproveitado e desdobrado por outros autores.

Esquivar-se de concepções generalizantes, assim, não significa apenas pôr as orientações tradicionais entre parênteses, mas constatar que se falo de estilo, posso fazê-lo apenas de modo parcial: no limite, cada texto é um texto, com estratégias próprias e, em certa medida, irrepetíveis - o que não impede que, no interior da prática escritural desse ou daquele escritor não haja gestos repetidos.

De modo que não se trata mais de procurar saber o que é ou deixa de ser "O estilo" como grande categoria, mas como funciona um estilo a partir de aspectos,

\footnotetext{
${ }^{18}$ Em Texto, crítica, Escritura, Leyla Perrone-Moisés propõe que haja "um estilo para a escrevência e outro para a escritura" (PERRONE-MOISES, 1978: 37). Trato do assunto no capítulo seguinte.
} 
relações: relações traçadas entre obsessões temáticas, situações ficcionais, estratégias discursivas etc.

Em suma: recortado, absorvido, desestabilizado e, em certa medida, confundido com o conceito de escrita, não estarei mais falando do estilo, mas de um estilo: estilo de escrita.

Talvez essa seja uma maneira de não se abandonar o conceito em virtude dos problemas que tradicionalmente o compõem: problema para o qual, em certa medida, Deleuze (2004) não deixa de chamar atenção:

Charme e estilo são termos inadequados, seria necessário encontrar outros, substituí-los. É que, simultaneamente, enquanto o charme dá à vida uma potência não pessoal, superior aos indivíduos, o estilo concede à escrita um fim que lhe é exterior, que extravasa o escrito. E trata-se do mesmo: a escrita não tem a sua finalidade em si própria, precisamente porque a vida não é algo pessoal (Deleuze, 2004, p. 16) ${ }^{19}$.

19 Tomo a liberdade de repetir a citação, já referida nas considerações iniciais da presente dissertação. 


\section{3 \\ Escrita e escrevência}

(...) à medida que o estilo se absorve em escritura, o sistema se desfaz em sistemática, o romance em romanesco, a meditação em fantasmática (...)

Roland Barthes, prefácio a Sade, Fourier, Loyola.

Segundo Leyla Perrone-Moisés (1978), o conceito barthesiano de escritura é um conceito operatório. Eminentemente abstrato, aplicá-lo de modo direto a autores, obras e textos (ou trechos de) com vistas a classificar, localizar, julgar etc. é passar ao largo do que ele tem a oferecer de potência. É preciso ter em mente, portanto, que a noção de escritura levanta antes um campo de problema ${ }^{20}$ que um receituário (vocábulo, aliás, dos mais inapropriados) - motivo pelo qual creio que seja possível pensar o conceito de estilo passando pelo de escritura: se este é eminentemente operatório, pode ser então que nos ajude a (re)pensar aquele.

Como ponto de partida, detenho-me por um instante na questão da tradução do termo francês écriture para escritura, em português.

Creio que traduzir "écriture" para "escritura" seja uma boa estratégia para que se marque um lugar teórico, distinguindo-se, assim, uma concepção instrumental da linguagem (a "escrita", pura e simplesmente) de outra (a "escritura") que fugiria a tal concepção. No caso do português, pode ser que a tradução seja até bastante rentável, uma vez que os falantes dessa língua, em geral, costumam usar o vocábulo "escrita" de modo indiferenciado. A despeito disso, particularmente não sou um entusiasta dessa tradução.

\footnotetext{
${ }^{20}$ No sentido de que, nela, encontrar-se-iam problematizados tanto o sujeito centrado como a linguagem em sua função instrumental/transitiva.
} 
Leyla Perrone, ao destacar um texto de Roland Barthes dos anos $1960{ }^{21}$ dos Essais critiques - "Ecrivains et écrivants" - , nos mostra que, ali, o teórico francês distinguia "escritores que escrevem algo" de "escritores que escrevem, ponto final"; e "escritura transitiva, portadora de mensagem" de "escritura intransitiva, produtora de sentidos". E arremata: "Traduziremos esses termos (pela ordem) da seguinte forma: escreventes, escritores, escrevência, escritura" (PerroneMoisés, 1978, p. 37. grifo meu).

$\mathrm{Na}$ redação da presente dissertação, devo dizer que o tempo todo estou sendo bem transitivo em minha dicção algo didática: procuro perceber, entender, explicar, enfim, tornar clara uma ideia. Neste particular, lembro que Barthes (1986), a certa altura de "Triunfo e ruptura da escritura burguesa", chama a atenção para o fato de que a clareza não é exatamente uma propriedade inata ao discurso, no mais encontrável em todos os tempos e lugares, mas que, pelo contrário, ela seria um artifício retórico.

De modo que, em português, lançar mão da tradução "escritura" seria imprimir uma espécie de marca somente naquele discurso que fosse "intransitivo", enquanto o outro, o da "escrita" [no sentido de escrevência], seria supostamente "comum" e/ou neutro em sua transitividade - quando na verdade não é bem isso que se dá. Se até mesmo a clareza, como propõe Barthes, é um artifício retórico, - embora tradicionalmente isso não seja admitido ${ }^{22}$, - concluise então que não há discursos inocentes, seja estes quais forem.

Faço essas observações para valorizar o termo escrevência que temos em mãos: a meu ver, mais rentável que opor "escritura" e "escrita", seria opor (pelo menos no caso do português) "escrita" e "escrevência".

Com isso, creio eu, obtém-se um duplo ganho: 1) Marca-se não aquele tipo de discurso que se propõe abrir/disseminar sentidos, mas sim aquele que logra limitar as significações (evitando o paradoxal) em prol da instrumentalidade passando-se por “normal”. 2) Põe-se às claras a ideia de que não existem "falares

\footnotetext{
${ }^{21}$ Momento que seria, segundo a autora, o de sua "fase estruturalista" (PERRONE-MOISÉS, 1978: 37).

${ }^{22}$ Mencione-se, a título de ilustração, do "Exórdio" de Apologia de Sócrates, quando Sócrates lograva persuadir os cidadãos de Atenas de sua inocência [frente à acusação de que corrompia os jovens] sublinhando sua linguagem que, ao contrário da dos sofistas - "hábeis oradores" -, seria um "falar comum", "justo", desprovido de "orações ornadas por belas frases e palavras" (PLATÃO, 1996:63) e, por isso mesmo, verdadeiro. Ou seja: o pretenso "falar comum" e "justo" (transitivo, instrumental) de Sócrates, embora este não admita, é um falar retórico.
} 
comuns" e/ou "justos": a linguagem que possui semelhante pretensão, é bom que seja assinalada com algo que a distinga.

Dizendo de outro modo: ao invés de se marcar com a tradução "escritura" o que seria uma espécie de exceção frente ao uso corrente, assinala-se, através do vocábulo pouco usual em português "escrevência”, justamente aquilo que é tido como ponto pacífico em seus expedientes. Feitas essas considerações, podemos pensar que nem só por ser instrumental determinado discurso seria "justo" ou neutro em suas propriedades, muito pelo contrário: junto à clareza (e ao valor-uso de que ela é o meio), não raro encontra-se aquela "intenção permanente de persuasão" de que falava Barthes (Barthes, 1986, p.149).

A partir de agora, tratarei o termo francês écriture por escrita, em português. À escrita, por sua vez, oporei o termo escrevência. ${ }^{23}$

Creio que seja pertinente para o contexto do presente capítulo fazerem-se sucintas considerações, via Leyla Perrone-Moisés (1978), sobre aspectos das noções de escrita e estilo na obra de Roland Barthes entre O grau zero da escritura (livro de 1953) e O prazer do texto (de 1973), passando pelos Ensaios Críticos da década de 1960.

Antes de mais nada, diga-se que minha intenção não é destrinchar o problema da instabilidade entre os dois conceitos nas sucessivas reformulações de Barthes, problema esse que, segundo a pesquisadora, é um dos mais espinhosos da teoria barthesiana ${ }^{24}$. Minha intenção, portanto, é apenas observar um movimento para em seguida passar adiante.

Em Texto, Crítica, Escritura, ao trabalhar com as noções de escrita e escrevência, Leyla Perrone supõe que haja um estilo para a escrita, que seria transitório, precário e, sobretudo, irrepetível em seus limites/contornos; e um estilo para a escrevência que, pelo contrário, seria apreensível, estável e repetível. Ao primeiro, ela chama "estilo de escritura" - para nós, "estilo de escrita". Ao segundo, naturalmente, "estilos de escrevência":

\footnotetext{
${ }^{23}$ A palavra "escritura", portanto, será utilizada somente quando de citações de livros cuja tradução seja esta.

24 “(...) a definição do estilo e de seu lugar nessas distinções é o problema mais espinhoso da teoria barthesiana" (PERRONE-MOISÉS, 1978, p. 38).
} 
Um autor profundamente engajado em sua história pode ser um mero escrevente, se seu engajamento fundamental não se travar com a própria linguagem. Portanto, a relação com a sociedade já não basta para caracterizar a escritura. Por outro lado, deduzimos que existe um estilo para a escrevência e outro para a escritura. Mais precisamente: o estilo de escritura é único e irrepetível, enquanto os estilos da escrevência se repetem (Perrone-Moisés, 1978, p. 37. grifo meu).

Quanto ao conceito de escrita em $O$ grau zero da escritura, diga-se que a questão do engajamento com a sociedade é um ponto digno de nota, posto constitua uma fase do pensamento de Roland Barthes. No livro em questão, apesar de a escrita não se configurar como mero instrumento de comunicação mas, pelo contrário, como linguagem "livremente produzida" 25 (Barthes, 1986, p. 125), ele possuiria ainda certa vocação, por assim dizer, sociológica: “A definição do Degré zéro tem amarras fundamentalmente sociológicas. Sem esquecer o compromisso da escritura com a literatura, Barthes estava então mais atento a seu compromisso com a história" (Perrone-Moisés, 1978, p. 41).

Quanto ao estilo [em $O$ Grau zero], este concernia àquilo que no escritor haveria de mais secreto e individual: situando-se ao nível de uma "biologia", de modo algum ele seria, como a escritura, uma escolha consciente: "Seja qual for seu refinamento, o estilo tem sempre algo de bruto: é uma forma sem destinação, o produto de um impulso, não de uma intenção (...)" (Barthes, 1986, p. 122). Trazendo o corpo [o estilo teria algo de biológico] mas não explorando ainda, a rigor, seu aspecto pré-individual - como o faz Giorgio Agamben (2007) em "Genius" -, em 1953 a concepção de "estilo" de Barthes ainda estaria algo próxima da concepção individualizante da estilística tradicional.

Leyla Perrone, então, mostra as mudanças que começam a se processar no pensamento de Barthes no tocante à relação estilo-escrita:

À medida que Barthes afina seu ouvido para o inconsciente, a distinção entre estilo e escritura, esboçada no Degré zéro, sofre alguns deslocamentos. Suas redefinições nos permitem ver por que o estilo (como valor isolado) está do lado da escrevência, enquanto na escritura o estilo se transmuta em algo diverso (Perrone-Moisés, 1978: $38)$.

\footnotetext{
${ }^{25}$ A expressão "livremente produzida", hoje, é passível de problematizações: todo discurso, de um modo ou de outro, supõe um público (ainda que virtual, inscrito no texto) ao qual se destina - sem falar em todo o aparato editorial e/ou institucional que o veicula.
} 
Aproveitando o vocabulário que discutíamos acima em torno dos problemas de tradução, é notável a ideia de que, como valor isolado, o estilo situe-se, para Roland Barthes, no âmbito da escrevência. Em outras palavras: não recortado pelo campo de debate da escrita - que o crítico deslocava incessantemente e levava à frente -, o conceito em questão fatalmente estaria sujeito: 1) ou aos problemas que tradicionalmente o compõem (como a velha oposição do fundo à forma ou a dualidade entre o coletivo e o individual), ou 2) à instrumentalidade de discursos previamente codificados, a saber, os discursos da escrevência:

O escrevente não exerce nenhuma ação técnica sobre a fala; ele dispõe de uma escritura comum a todos os escreventes, espécie de Kö̈nè na qual se pode, certamente, distinguir dialetos (por exemplo: marxista, cristão, existencialista), mas muito raramente estilos (Barthes, Roland. Apud Perrone-moisés, 1978, p. 38. grifo meu).

Note-se que nesta citação (segundo me consta, do livro Essais Critiques, dos anos 1960), Barthes fala em "estilos" como algo que se opõe a "dialetos" (esses dialetos, tanto quanto percebo, seriam análogos à ideia de estilo como valor isolado). Isto é, estes estariam para a escrevência ("dialeto"/estilo marxista, existencialista, cristão etc.) ali onde aqueles (os "estilos" /escrita) configurar-seiam como maneira singular de tratar a linguagem, rechaçando, quais sejam, codificações históricas generalizantes.

Em texto já da década de 1970, algo semelhante pode ser verificado: o conceito de estilo, como valor isolado, é referido segundo sua problemática tradicional. A título de ilustração, cite-se uma passagem do prefácio à Sade, Fourier, Loyola - de onde tirei a epígrafe que abre o presente capítulo:

O estilo supõe e pratica uma oposição entre o fundo e a forma; é o compensado de uma substrução; já a escritura acontece no momento em que se dá um escalonamento de significantes tal que nenhum fundo de linguagem mais possa ser identificado; porque ele é pensado como uma 'forma', o estilo implica uma 'consistência'; a escritura, para retomar uma terminologia lacaniana, só conhece 'insistências' (Barthes, 1990, p. 9-10). 
Leyla Perrone-Moisés, estudiosa afinada com as nuances do pensamento de Roland Barthes e principal divulgadora de sua obra no Brasil, nos situa: "A valorização progressiva do inconsciente nos textos de Barthes, leva-o assim a uma sutil reformulação dos problemas da escritura. O estilo, mero revestimento formal, passa a ser conotado negativamente como atributo da escrevência" (PerroneMoisés, 1978, p. 39).

Entre os sucessivos "deslocamentos" operados na teoria barthesiana, importa ressaltar dois aspectos relevantes: 1) à medida que o inconsciente ganha importância nas teorizações de Roland Barthes sobre a escritura (a partir da década de 1970), o corpo - deixado de lado, segundo Leyla Perrone, na fase “estruturalista" dos anos 1960 - entra em cena novamente [lembre-se que em $O$ grau zero, no que toca ao conceito de estilo, o corpo já aparecia, embora ainda não explorado como potência teórica]. 2) Como valor isolado, o conceito de estilo (que, como entendo, seria análogo à ideia de "dialeto" nos Ensaios Críticos) situar-se-ia no âmbito da escrevência: estilo/dialeto marxista, cristão, realista etc. Nesse sentido, os próprios "estilos de época" da disciplina canonizada Literatura, em certo sentido, seriam estilos de "escrevência" na medida em que, após o fulgor inicial, reproduzem-se até o esgotamento ao institucionalizam-se. Assim é que a repetição estaria para o estilo como valor isolado ali onde a transitoriedade estaria para o estilo absorvido em escrita: estilo de escrita, "estilos" [tal qual se vê nos Ensaios Críticos], assinatura ${ }^{26}$, "um estilo" (como usará Deleuze) - essas palavras-expressões, grosso modo, seriam mais ou menos análogas em sua significação teórica.

Em suma: se em $O$ grau zero da escritura o estilo configura-se como instância eminentemente fisiológica e individual e a escrita como uma escolha consciente, na fase do Prazer do texto o estilo se absorve em escrita (vide a epígrafe que abre este capítulo) ao mesmo tempo em que esta, ao apontar para o inconsciente, resgata aquilo que nele [no estilo] havia de potência, por assim

\footnotetext{
${ }^{26}$ No que diz respeito ao conceito de assinatura, diz-nos Gilles Deleuze (1997): “O expressivo é primeiro em relação ao possessivo, as qualidades expressivas ou matérias de expressão são forçosamente apropriativas (...). Essas qualidades são assinaturas, mas a assinatura, o nome próprio, não é a marca constituída de um sujeito, é a marca constituinte de um domínio, de uma morada. A assinatura não é a indicação de uma pessoa, é a formação aleatória de um domínio (...). Colocamos nossa assinatura num objeto como fincamos nossa bandeira na terra (DELEUZE, 1997, p.123).
} 
dizer, indomável: aquela "biologia" a que Barthes se referia (mas ainda não explorava nesse sentido) em 1953.

Do Degré zéro ao Plaisir du texte, podemos perceber uma mudança na noção de escritura, numa evolução que se delineia não por contradição mas por contínuo deslocamento (...). A escritura é aí, antes de tudo, um engajamento consciente. As obras seguintes deslocarão pouco a pouco o problema, segundo um trajeto que não invalida ou esquece as colocações do Degré zéro, mas faz variar a ênfase dada a um ou outro aspecto da enunciação (Perrone-Moisés, 1978, p. 41).

Em "Crítica e escritura”, Leyla Perrone-Moisés (1978) propõe que, se de um lado as relações entre os conceitos de estilo e escrita apresentam problemas, posto se comportem de maneira sobretudo instável nas diferentes fases da carreira de Roland Barthes, de outro lado as noções gerais de enunciação e transitoriedade permanecem estáveis - ao menos no correr das sucessivas redefinições e deslocamentos operados pelo crítico-escritor francês no conceito de escritura:

Desde já ressalte-se o seguinte: a escritura é uma questão de enunciação. Este ponto nos parece fundamental porque, como veremos, é o que se manterá estável nas sucessivas redefinições barthesianas da escritura. (...) A questão da transitoriedade da escritura (que não pode sobreviver na repetição) é também uma constante que se manterá nas colocações futuras (Perrone- Moisés, 1978, p. 36-37).

Acrescente-se que a enunciação (inerente à concepção de escrita de Roland Barthes) é um valor que põe o sujeito em crise ao mesmo tempo em que a transitoriedade repele a atuação da escrevência, suas repetições, automatizações e normatizações escamoteadas. Tanto quanto posso perceber, trata-se de um duplo movimento: ao mesmo tempo em que a escrita escapa à intenção [ao vício] de veicular sentidos dirigidos - os quais, como sugere Leyla na citação acima, sobrevivem na repetição -, o enunciador perde o (pretenso) domínio sobre a linguagem na qualidade de instrumento estável/manejável. 
A escritura ocorre onde há enunciação, e não uma mera sequência de conceitos. Um discurso de puro saber pode passar à escritura quando sofre o 'ataque de paranóia' e é atravessado por uma 'lufada de enunciação' (Perrone-Moisés, 1978, p.40).

Seria possível que um estilo fosse algo como uma passagem, um movimento? Que não se localizasse nem (só) ao lado do plano individual nem (só) ao lado do plano coletivo - mas que, pelo contrário, circulasse em meio a essas instâncias? Nesse caso, tratar-se-ia ainda de "estilo"? Ou bastaria falarmos em "escrita"?

Gilles Deleuze, em mais de uma ocasião, propõe que um estilo seja um devir. (Tenho a intuição de que, para este, estilo e escrita seriam termos (quase que) indiferenciados. No entanto, o filósofo, aqui e ali, não deixa de usar: "um estilo é..."

Sem entrar, por enquanto, em considerações teóricas mais detidas no que toca aos aspectos deste ou daquele ensaio, destaco passagens diversas que, em seu contexto, as noções de estilo e devir encontram-se relacionadas: "Criação sintática, estilo, tal é o devir da língua: não há criação de palavras, não há neologismos que valham fora dos efeitos de sintaxe nos quais se desenvolvem" ${ }^{27}$; “Os devires são o que há de mais imperceptível. São actos que só podem estar contidos numa vida e expressos num estilo" 28; "As figuras estéticas (e o estilo que as cria) não tem nada a ver com a retórica. São sensações: perceptos e afectos, paisagens e rostos, visões e devires" ${ }^{29}$; "O que denominamos um estilo, que pode ser a coisa mais natural do mundo, é precisamente o procedimento de uma variação contínua. (...) É aí que o estilo cria língua. É aí que a linguagem se torna intensiva, puro contínuo de valores e de intensidades" 30

\footnotetext{
${ }^{27}$ (DELEUZE, 1997, p. 16) - "A literatura e a vida".

${ }^{28}$ (DELEUZE, 2004, p.13) - "Uma Conversa, o Que É, Para Que É Que Serve?".

${ }^{29}$ (DELEUZE, 1992, p. 209) - "Percepto, afecto e conceito".

${ }^{30}$ (DELEUZE, 1995, p. 41-43) - "20 de Novembro de 1923 - postulados da linguística".
} 


\section{4 \\ Dono do mundo}

Macedo é dado a estudos de ornitologia. Certo dia, indo por uma rua, um "tílburi à disparada" quase o lança ao chão - o que o faz entrar, por acaso, em uma loja de belchior.

Em meio às velhas quinquilharias que aí se vendiam, - "panelas sem tampa, tampas sem panela, botões, sapatos, fechaduras (...)", - uma gaiola pendurada à porta chama sua atenção: nela se agitava um canário cuja "cor", "animação" e "graça" eram as únicas coisas que conferiam vida àquele ambiente morto, desolado e escuro. Indignado com o destino do pássaro, murmura para si: "Quem seria o dono execrável deste bichinho, que teve ânimo de se desfazer dele por alguns pares de níqueis? (...)" (Assis, 2008, p. 568).

À pergunta do personagem-narrador segue-se a resposta do animal, abrindo, assim, o espaço inverossímil - seria mais justo dizer: o jogo de forças com a verossimilhança - explorado pelo conto:

E o canário, quedando-se em cima do poleiro, trilou isto:

- Quem quer que sejas tu, certamente não estás em teu juízo. Não tive dono execrável, nem fui dado a nenhum menino que me vendesse. São imaginações de pessoa doente; vai-te curar, amigo... (idem)

Insistindo que o bicho não poderia ter parado ali sem motivo - e Macedo, na qualidade de cientista-naturalista, precisa de motivos -, propõe então que o senhor ao fundo da loja - e proprietário do estabelecimento - haveria que ser seu dono.

O canário inicia a lição:

- Que dono? Esse homem que aí está é meu criado, dá-me água e comida todos os dias, com tal regularidade que eu, se devesse pagar-lhe os serviços, não seria com pouco; mas os canários não pagam criados. Em verdade, se o mundo é propriedade dos canários, seria extravagante que eles pagassem o que está no mundo (idem). 
$\mathrm{O}$ ornitologista pasma tanto com as ideias quanto com a linguagem do animal, que posto lhe "entrasse pelo ouvido como de gente, saía do bicho em trilos engraçados" (idem).

Diante do absurdo, olha à sua volta para se certificar de que não estava sonhando: a rua, a loja escura, os objetos ao redor, tudo ainda era o mesmo.

Como o pássaro continuasse de um lado para outro, Macedo lança-lhe a questão fundamental: "Mas, perdão, que pensas deste mundo? Que coisa é o mundo?"

Sem titubeio, a resposta do interlocutor:

O mundo - redargüiu o canário com certo ar de professor -, o mundo é uma loja de belchior, com uma pequena gaiola de taquara, quadrilonga, pendente de um prego; o canário é senhor da gaiola que habita e da loja que o cerca. Fora daí, tudo é ilusão e mentira (Assis, 2008, p. 568).

Publicado em 1895 na Gazeta de Notícias e, posteriormente, nas Páginas Recolhidas, "Ideias de Canário" é uma aula de perspectivismo. Essa aula, contudo, não é ministrada por aquele que deveria ser o professor, - o homem dado a estudos de ornitologia, o cientista, - mas pelo pássaro que, diante da perplexidade daquele (a qual só faz aumentar ao longo da narrativa), destrói-lhe alguns dos pressupostos: pretensão à objetividade, fé na estabilidade dos conceitos, desejo de apreender o mundo em sua totalidade.

Mas se o assombro do narrador não para de crescer ao longo da narrativa, o que não se dirá da liberdade do canário? De início dono da loja, depois dono de um jardim, ao final do conto, o pássaro seria nada mais nada menos que dono do mundo.

A aula do animal, como se vê, não é sem consequências. E se método há em sua dicção, este se orienta antes por uma lógica "constelacional" - para citar uma noção de Luiz Costa Lima (2002) - que por uma linear-discursiva. Deixo citado o diálogo que encerra a narrativa: 
Falei ao canário com ternura, pedi-lhe que viesse continuar a conversação, naquele nosso mundo composto de um jardim e repuxo (...)

- Que jardim? que repuxo?

- O mundo, meu querido.

- Que mundo? Tu não perdes os maus costumes de professor. O mundo - concluiu solenemente - é um espaço infinito e azul, com o sol por cima.

Indignado, retorqui-lhe que, se eu lhe desse crédito, o mundo era tudo; até já fora uma loja de belchior...

- De belquior? - trilou ele às bandeiras despregadas. - Mas há mesmo lojas de belchior? (Assis, 2008, p. 570).

Com o intuito de retomar os conceitos trabalhados no primeiro capítulo da presente dissertação, - valor-corpo, valor-trabalho e valor-gênio, - convoco aspectos das noções nietzschianas de genealogia e perspectivismo.

Em "Friedrich Nietzsche: perspectivismo e superação da metafísica", artigo publicado na revista Comum, Noéli Correia de Melo Sobrinho propõe que "o pensamento de Nietzsche não pode ser desligado do impulso crítico iniciado com Hume e sobretudo Kant" (Melo Sobrinho, 2004, p.5), impulso esse que o filósofo radicalizou e transformou em genealogia e perspectivismo - cuja lógica, por sua vez, consiste no privilégio do corpo sobre o espírito; da aparência sobre a essência; e, por fim, da arte sobre a verdade [e não, em cada um desses binômios, o contrário, como se considera ao longo da história do pensamento ocidental] ${ }^{31}$.

A crítica em Nietzsche, desse modo, configura-se como um duplo movimento que se dá na dinâmica desconstrução/construção: ao mesmo tempo em que reage aos pressupostos da metafísica, desconstruindo-os, ela age sobre a vida ao reclamar para si a carga criativa inerente a toda vontade de poder: trata-se, como mostra Noéli Correia, do "impulso artístico que se encontra na base corporal da sua genealogia e do seu perspectivismo". A partir desse impulso artístico e dessa base corporal irredutível, assim, Nietzsche cria as condições a partir das quais se pode construir a "nova filosofia" (idem).

É o que propõe Gilles Deleuze (s/d) em passagem do primeiro capítulo de Nietzsche e a filosofia - "O trágico":

\footnotetext{
${ }^{31}$ Não se trata aqui, contudo, de se empreenderem meras operações de inversão entre os binômios em questão; antes, trata-se de se proporem desierarquizações entre os mesmos.
} 
O elemento diferencial não é crítico do valor dos valores, sem ser também o elemento positivo de uma criação. É por isso que a crítica nunca é concebida por Nietzsche como uma reacção, mas como uma acção (Deleuze, s/d: 7. grifo meu).

Segundo o filósofo francês, um dos motores dessa filosofia que se faz a "golpes de martelo" é a "inversão crítica" que está implicada no conceito de valor (Deleuze, s/d: 6).

Tal inversão consiste no seguinte: acredita-se que essa ou aquela avaliação supõe valores a partir dos quais os fenômenos podem ser apreciados. Nesse caso, os valores em questão apresentar-se-iam antes como instâncias enrijecidas/fixadas que [como instâncias] mutáveis/flexíveis; isto é, eles serviriam de bases préestabelecidas a serviço do julgamento e/ou da avaliação a ser feita. A situação muda completamente, contudo, se se pensa que não são as avaliações que supõem valores a elas anteriores, mas sim o contrário: a depender dos "pontos de vista de apreciação" (das perspectivas) que enformam as avaliações, estas é que criam e/ou fazem derivar de si os valores propriamente ditos. Esse tópico nos parece fundamental. A esse respeito, diz-nos Deleuze:

\begin{abstract}
O problema crítico é esse: o valor dos valores, a avaliação donde procede o seu valor, portanto o problema da sua criação. As avaliações, referidas ao seu elemento, não são valores, mas maneiras de ser, modos de existência daqueles que julgam e avaliam (...). Eis o essencial: $O$ elevado e o baixo, o nobre e o vil não são valores, mas representam o elemento diferencial donde deriva o próprio valor dos valores (Deleuze, s/d: 6. grifo meu).
\end{abstract}

Esse elemento diferencial - sempre perspectivado - que concerne a toda avaliação serve-nos, pois, como boa exemplificação daquele duplo movimento deflagrado (e, no mais, exigido) pelo projeto crítico nietzschiano: a par da desconstrução "de todas as categorias fundamentais da metafísica" (Melo Sobrinho, 2004, p. 6) é necessário que se erija, concomitantemente, um método de análise a partir do qual se possa investigar tanto a origem e a história dos valores como as "configurações culturais" (idem) a partir das quais esses valores são criados/concebidos. 
O método de análise em questão é a genealogia da vontade de poder método do qual o perspectivismo é ao mesmo tempo expressão e consequência inevitável.

Do fundo da loja de belchior, o vendedor dirige-se até Macedo e perguntalhe se este tem interesse em comprar o canário. Macedo toma conhecimento de que o pássaro fora adquirido, junto a uma coleção de navalhas, com um barbeiro: "As navalhas estão em muito bom uso" - propõe-lhe o velho. "Quero só o canário" - retorque o ornitologista.

Paguei-lhe o preço, mandei comprar uma gaiola vasta, circular, de madeira e arame, pintada de branco, e ordenei que a pusessem na varanda da minha casa, de onde o passarinho podia ver o jardim, o repuxo e um pouco de céu azul (Assis, 2008, p. 569).

A intenção do cientista não era das mais modestas: a partir do estudo minucioso e exaustivo do canário falante, ele iria "assombrar o século" com as descobertas que faria, as quais haveriam que ser enviadas ao Instituto Histórico e às universidades alemãs...

Comecei por alfabetar a língua do canário, por estudar-lhe a estrutura, as relações com a música, os sentimentos estéticos do bicho (...). Feita essa análise filológica e psicológica, entrei propriamente na história dos canários, na origem deles (...). Conversávamos longas horas, eu escrevendo as notas, ele esperando, saltando, trilando (idem).

Passadas algumas semanas, Macedo não dormia, alimentava-se mal, tinha febre: "Todo eu era canário" (idem).

Como alguns de seus apontamentos lhe parecessem imprecisos, seja porque o animal não se expressara com a devida clareza, seja porque ele mesmo talvez o tivesse compreendido mal, o ornitologista pede-lhe então [ao canário] que lhe fosse repetida a definição do mundo - tópico que, particularmente, sofrera 
drásticas alterações; e cujas conclusões, se ao início da pesquisa pareciam simples ao estudioso, passavam agora a parecer-lhe "temerárias":

- O mundo - respondeu ele - é um jardim assaz largo com repuxo no meio, flores e arbustos, alguma grama, ar claro e um pouco de azul por cima; o canário, dono do mundo, habita uma gaiola vasta, branca e circular, de onde mira o resto. Tudo o mais é ilusão e mentira (idem).

Pois ali onde Macedo, mediante valor-trabalho ${ }^{32}$, é tomado por vontade de verdade (encontrar o significado unívoco do pássaro, do mundo e, por que não, da vida), o trilar do bicho, mediante valor-corpo, oferece-lhe perspectiva e vontade de poder.

De "O cônego ou metafísica do estilo" a "Ideias de Canário", valor-trabalho e valor-corpo, embora mudem de figura quanto à sua representação nos respectivos enredos, mantêm, por assim dizer, suas funções primordiais: fazer com que o efeito sensível do corpo relativize - para não dizer: torne inoperante - a centralidade da consciência e do Logos (valor-trabalho) na qualidade de discurso/instrumento triunfante.

Em "O cônego", esse efeito sensível é representado pelo idílio entre as palavras, inconsciente e arredio ao controle de Matias, ao passo que em "Ideias de Canário" ele é representado pelo trilar sonoro e desarticulado do pássaro, cuja "lição" resulta em mostrar a Macedo que o valor das coisas [no caso do enredo do conto, do "mundo"] é produto de avaliações sempre perspectivadas dos fenômenos.

Essas avaliações, por sua vez, são maneiras de ser, modos de existência. Cito novamente o trecho em que Deleuze toca nesse tópico fundamental: "As avaliações, referidas ao seu elemento, não são valores, mas maneiras de ser, modos de existência daqueles que julgam e avaliam (...)" (DeleuzE, s/d: 6).

Interessante notar que, em ambos os casos, o que está em jogo não é de somenos: trata-se de por em xeque a autoridade de dois grandes "medalhões" (para falarmos em termos machadianos) do século XIX tupiniquim: a figura

\footnotetext{
${ }^{32}$ Reintroduzo, aqui, as noções do primeiro capítulo.
} 
eclesiástica e a figura do cientista positivo - ambos perseguindo, cada qual à sua maneira (mas valendo-se do mesmo instrumento), a Verdade.

No correr dos capítulos anteriores, em mais de uma ocasião, falei em gesto repetido. Penso que não seja exagero dizer que esse é um dos gestos repetidos (ou seja, uma das constantes semiológicas) recorrentes na ficção machadiana: a perda/relativização da centralidade do Logos seja pela introdução do elemento "inconsciente", seja pela introdução do elemento "sonoro" ${ }^{33}$, seja, ainda, pela introdução do elemento "loucura". Trata-se, a meu ver, de um motor do estilo e da escrita: obsessões que se repetem de modos diferentes nos enredos mas que apontam para direções/consequências semelhantes.

A título de ilustração, cite-se o primeiro parágrafo de "Ideias de Canário" que, além de valorizar a potência sonora/desconstrutora do trilar do pássaro, como vimos, faz menção, também, à loucura - ainda que esta última, nesse caso particular, sirva de estratégia discursiva para que o leitor do século XIX aceite, um tanto comodamente, o inverossímil e o absurdo da narrativa ${ }^{34}$ :

Um homem dado a estudos de ornitologia, por nome Macedo, referiu a alguns amigos um caso tão extraordinário que ninguém lhe deu crédito. Alguns chegam a supor que Macedo virou o juízo. Eis aqui o resumo da narração (Assis, 2008, 567. grifo meu).

Seja como for, voltemos à genealogia e ao perspectivismo de Nietzsche para, nos capítulos que se seguem, retomarmos pontos que, embora pensados por outros caminhos, em certa medida lhes dizem respeito.

$$
* * *
$$

\footnotetext{
${ }^{33}$ A dimensão inconsciente das atividades do corpo corresponde, no caso, à presença de todo e qualquer efeito sensorial; como se trata do conto "Ideias de canário", a sonoridade é, naturalmente, privilegiada.

${ }^{34}$ Diz-nos Antonio Candido: "O eixo do romance oitocentista é pois o respeito inicial pela realidade, manifesto principalmente na verossimilhança que procura imprimir à narrativa (...). No Romantismo, o afastamento dessa posição ideal se fez na direção e em favor da poesia; mais tarde, no Naturalismo, far-se-ia na direção da ciência e do jornalismo. Tanto num quanto noutro porém, permanece o esteio da verossimilhança e, mais fundo, a disposição comum de sugerir certo determinismo nos atos e pensamentos do personagem" (CANDIDO, 1975, p. 111. grifo meu ).
} 
O ponto de partida do perspectivismo, segundo Noéli Correia (2004), é "a constatação de que o homem não se pode abster de julgar. O homem [Mensch] é um animal que mede, o seu olhar é já sempre um juízo" (Melo Sobrinho, 2004, p. 6). Contudo, acreditar que para cada coisa haveria que existir apenas um conceito, - ao tomar essa coisa como "possuindo uma existência em si, própria, una, idêntica, essencial" (idem), - foi seu erro original.

Quando, acima, tratávamos da "inversão crítica" que, em Nietzsche, está implicada no conceito de valor, vimos que os valores não são anteriores às avaliações; formadas sempre a partir de um "ponto de vista de apreciação", para falarmos com Deleuze, estas é que precedem (e criam) aqueles. Assim, "todo julgamento realizado sobre o mundo", diz-nos Noéli Correia, “implica já uma avaliação que leva em consideração o impacto que os objetos externos exercem sobre os homens" (Melo Sobrinho, 2004, p. 6).

Esse impacto se dá através dos sentidos - audição, visão, tato, olfato etc. A visão, contudo, possui papel de destaque nesse contexto, uma vez que é ela que traz à tona um tópico indispensável para o problema do conhecimento: o "mundo da aparência" que, por sua vez, encontra-se sempre mediado por um olhar ("atividade de excitação visual"); mediação essa sem a qual, como mostra Noéli Correia, "não haveria nem representação, nem memória, nem vontade, nem conhecimento" (idem).

Nesse sentido, a ideia exposta no primeiro parágrafo da presente sessão não poderia ser mais justa: o simples ato de lançar o olhar sobre algo, ao contrário do que em geral se pensa, é já um ato que produz julgamento, uma vez que esse olhar recolhe para si imagens e sensações nunca desinteressadas a respeito do "mundo exterior" e das coisas. De onde a radicalidade resultante da noção nietzschiana de perspectivismo: o erro e a aparência configurando-se ambos como a base do conhecimento:

Por outro lado, se o conhecimento possível é aquele que provém dos sentidos, especialmente da visão, deve-se concluir que: 'O erro, a aparência, é portanto a base do conhecimento. Unicamente a comparação de aparências numerosas engrendra verossimilhança, que é portanto um grau da aparência' (Melo Sobrinho, 2004, p. 7). 
Parece-me que Machado de Assis não era insensível a esse estado de coisas. A esse respeito, cite-se uma passagem paradigmática, - para não dizer "nietzschiana", - do conto "O cônego ou metafísica do estilo".

Quando nosso padre Matias suspende a pena à procura de seu adjetivo ideal, o narrador em terceira pessoa, como vimos no primeiro capítulo, suspende o fluxo narrativo e propõe ao leitor o inverossímil convite: "Subamos à cabeça do cônego".

Um detalhe, contudo, não foi por mim mencionado: o alto teor crítico, analítico e reflexivo (ao qual eu gostaria de tomar a liberdade de chamar, ousando um pouco, de "ensaístico") da intervenção metaficcional feita pelo narrador.

Pois antes de entrar em contato com o universo virtual dos fluxos cerebrais de Matias, o leitor recebe do narrador, por assim dizer, um "piparote" - para mais uma vez falarmos em termos machadianos - em forma de aviso. Cite-se a passagem à qual me refiro:

Subamos à cabeça do cônego.

Upa. Cá estamos. Custou-te, não, leitor amigo? É para que não acredites nas pessoas que vão ao Corcovado, e dizem que ali a impressão da altura é tal, que o homem fica sendo coisa nenhuma. Opinião pânica e falsa, falsa como Judas e outros diamantes. Não creias tu nisso, leitor amado. Nem Corcovados, nem Himalaias valem muita coisa ao pé da tua cabeça, que os mede. Cá estamos. Olha bem que é a cabeça do cônego (Assis, 2008, p.529).

"Olha bem que é a cabeça do cônego"! De nossa parte, poderíamos acrescentar: e veja que tanto a 'altura' do Corcovado quanto a grandiosidade que se faz sentir pela autoridade da figura eclesiástica (e seu discurso) ${ }^{35}$ não são valores em si, mas impressões condicionadas (e sofridas) por um ponto de vista determinado [no caso, o olhar do leitor desavisado...].

Interessante notar que, logo após esse "piparote", o narrador engata sua teoria da escrita: a de que os vocábulos dividem-se e atraem-se por motivo de "diferença sexual": estratégia ficcional que descreve a "metafísica do estilo" de modo que esta concirna mais aos efeitos sensíveis do valor-corpo que à

\footnotetext{
${ }^{35}$ É preciso lembrar que Matias escrevia um sermão para ser pregado; além disso, recorre (julga recorrer) à inspiração divina (valor-gênio) para arrematar seus escritos.
} 
consciência do valor-trabalho - sublinhando, assim, a vontade de poder que se encontra em toda relação de forças.

Neste ponto, contudo, é preciso que se faça a seguinte observação. Se por um lado em "O cônego ou metafísica do estilo" Machado convoca seu leitor para uma espécie de tomada de consciência no que diz respeito à questão do olhar (o qual cria valores para o mundo a partir de pontos de vista sempre perspectivados), por outro lado ele valoriza, - e esse é o aspecto mais radical de sua "teoria" da escrita, - a não-consciência e impossibilidade de controle que caracterizam as forças em relação [no enredo do conto, essas forças são precisamente, como sugerido acima, o que há de sensível, de "sexual" e de dinâmico no jogo permanente de atração e repulsa entre os vocábulos].

Não basta dizer, assim, que é o olhar - e o olhar do homem - que dá as medidas do perspectivismo (trazendo a reboque a constatação de que todo conhecimento é aparência e, no limite, "erro" engendrado pela atividade de excitação visual). A isso, é preciso acrescentar, como propõe Noéli Correia, que:

Toda perspectiva, por outro lado, nasce no plano inconsciente do homem, mas se apresenta no plano das sensações e da consciência, ou seja, no plano do reconhecimento e da conclusão. Se isto está correto, então, é possível admitir que o afã de conhecer é talvez o impulso originário do animal inteligente, anterior mesmo às sensações, à consciência, e à vontade (Melo Sobrinho, 2004, p. 9. grifo meu).

Esse "impulso originário" anterior à consciência e à vontade é precisamente aquilo que faz com que a vontade de poder seja um elemento que diz respeito não apenas ao homem e seu olhar limitado, mas também - e sobretudo - a toda força que, em relação sempre dinâmica com outra(s) força(s), situa-se em âmbito pré tomada-de-consciência, se assim se pode dizer:

O homem abriga no seu ser orgânico a luta constante de uma multidão de forças umas contra as outras, combate cujo resultado aparente é a perspectiva inscrita na consciência enquanto instrumento através do qual o combate segue seu curso, criando sempre novas perspectivas (Melo Sobrinho, 2004, p. 14). 


\title{
5 \\ Rumo às Aparências
}

Em O ceticismo na obra de Machado de Assis, José Raimundo Maia Neto (2007) propõe que seu livro não é o primeiro a tratar da dimensão reflexiva cética na obra de Machado de Assis, mas é "o primeiro a tomar por ceticismo a tradição filosófica iniciada por Pirro - o pirronismo" (Maia Neto, 2007, p. 15).

Afinado com as orientações do filósofo, - e defensor ferrenho da ideia de que o escritor fluminense é cético por não poder ser considerado, em hipótese alguma, realista, - Gustavo Bernardo (2008) mostra que, se por um lado a crítica machadiana reconhece a relação da literatura de Machado com o ceticismo filosófico, por outro lado são poucos os que tratam do tema de modo a trazê-lo para o primeiro plano:

\begin{abstract}
Um dos primeiros trabalhos de Afrânio Coutinho, em 1940, chegou a tocar bem no tema do ceticismo machadiano, mas não o desenvolveu (...), enquanto Miguel Reale, em 1982, falou da sua filosofia sem enfrentar a questão do ceticismo (...). Depois deles, Kátia Muricy, em 1988, e Eunice Piazza Gai, em 1997, de fato enfrentaram o ceticismo de Machado, mas ainda restringindo-o às discussões científicas e higienistas da sua época (...) (Krause, 2008, p. 55).
\end{abstract}

Seja como for, a acepção que José Raimundo Maia Neto tem acerca do ceticismo é mais precisa e, no seu entender, constitui-se não como um aspecto lateral, mas como o fundamento mesmo da obra de Machado de Assis. Adianto que não partilho dessa posição, que me parece totalizadora e, por isso, desconsidera outras tendências importantes com que a escrita machadiana mostra afinidade, como as representadas, por exemplo, por Voltaire e Schopenhauer. A despeito disso, apóio-me em aspectos da sua argumentação para, a partir deles, destacar pontos que interessam.

Antes de mais nada, diga-se que meu interesse em articular ceticismo filosófico e traços da escrita machadiana deve-se ao tópico da suspensão do juízo (epoche). A partir da discussão que travei, sobretudo nos capítulos 2 e 3, em torno dos conceitos de estilo e de escrita (via Roland Barthes), me pareceu que o 
problema da intransitividade da escrita poderia, em certo sentido, aproximar-se dessa que, ao lado da zetesis (investigação) e da ataraxia (tranquilidade), é uma das etapas do percurso cético (a suspensão do juízo ou epoche).

Digo isso pelo seguinte motivo: sempre que me envolvo com a construção narrativa de Machado, tenho a sensação de que esses textos possuem envergadura epistemológica, na medida em que trabalham em tensão com tópicos caros ao pensamento ocidental, tais como: a relação entre corpo e espírito (ou exterior/interior, dentro/fora: relação da qual o conto-teoria "O espelho", por exemplo, é um paradigma); o problema das aparências e da ênfase na vida exterior ou empírica (que em sua ficção é uma nota quase que permanente - a qual, na chamada "segunda fase", no mais das vezes encontra-se em choque/tensão com juízos de ordem moral, sejam eles quais forem); a perda da predominância do logos ou da consciência em relação ao dado corporal, sensitivo, sonoro ou onírico; o descrédito ou ridicularização (também quase que permanentes) seja para com a figura eclesiástica [e a transcendência da Ideia], seja para com a figura do cientista positivo [e a fé no conhecimento] etc. Tudo isso, é importante dizer, sugerido via estratégia ficcional, ou seja, via compostos de sensações (para falarmos com Deleuze \& Guattari (1992) de "Percepto, afecto e conceito") e não através de conceitos filosóficos.

Arrisco dizer, além disso, que se há um procedimento geral [para além da muito comentada ironia] que perpassa sua ficção, esse procedimento é o do paradoxo. Cito algumas passagens da "Décima Segunda Série: Sobre o Paradoxo" de Lógica do sentido, na qual Gilles Deleuze teoriza sobre o assunto:

(...) o paradoxo se opõe à doxa, aos dois aspectos da doxa, bom senso e senso comum. Ora, o bom senso se diz de uma direção: ele é senso único, exprime a existência de uma ordem de acordo com a qual é preciso escolher uma direção e se fixar a ela (Deleuze, 1974, p. 78).

No senso (sentido) comum, 'sentido' não se diz mais de uma direção, mas de um órgão. Nós o dizemos comum, porque é um órgão, uma função, uma faculdade de identificação, que relaciona uma diversidade qualquer à forma do Mesmo. O senso comum identifica, reconhece, não menos quanto o bom senso prevê (Deleuze, 1974, p. 80).

(...) o paradoxo é a subversão simultânea do bom senso e do senso comum: ele aparece de um lado como os dois sentidos ao mesmo tempo do devir- 
louco, imprevisível; de outro lado, com o não-senso da identidade perdida, irreconhecível (Deleuze, 1974, p. 81).

De todo modo, esse foi o motivo que me levou a buscar referências no ceticismo: apostar na ideia de que a suspensão do juízo do cético poder-se-ia aproximar do binômio escrita e intransitividade - uma vez que, em ambos os casos, o que está em jogo, em certa medida, é o questionamento da possibilidade de, via linguagem verbal centrada em um sujeito, se chegar a uma asserção, julgamento, apreciação ou conhecimento último sobre um objeto dado.

Em termos sumários, vejamos, portanto, em que consiste o percurso traçado por José Raimundo Maia Neto em O ceticismo na obra de Machado de Assis; e em que medida aspectos desse percurso podem ser por nós aproveitados.

$* * *$

No livro em questão, o filósofo defende a tese de que a obra de Machado consiste em um percurso linear-evolutivo em direção a "uma dimensão reflexiva cética”. Citemos suas palavras:

Com efeito, a hipótese aqui assumida é que a totalidade da prosa ficcional de Machado pode ser organicamente compreendida a partir da indicação, primeiro de uma gestação, depois de uma evolução, de uma dimensão reflexiva cética (Maia Neto, 2007, p. 22. grifo meu).

Partindo de um ensaio de Victor Henaux traduzido por Machado de Assis "De l'amour des femmes pour les sots" ["Queda que as mulheres têm pelos tolos"] -, o autor aproveita as três categorias aí apresentadas para propor (e alicerçar) sua interpretação da obra do autor fluminense. São elas: a "mulher", o "tolo" e o "homem de espírito". Sua análise, portanto, depende da aceitação prévia, por parte do leitor, dessas três categorias, assim como de sua validade no que diz respeito a implicações teórico-conceituais. Que consistem, grosso modo, no seguinte:

Para Maia Neto, 
A mulher é o objeto central de reflexão do personagem observador, princípio de sua perturbação ao longo de toda prosa ficcional machadiana, sendo na consideração deste objeto que a perspectiva cética se desenvolve (Maia Neto, 2007: 41).

Isto é, na medida em que "ostentam", "afetam" e "fingem", as mulheres "representam a realidade em Machado, que é vista como fundamentalmente precária, pois identifica-se com a vida social” (Idem) - espaço de dissimulações e aparências conflitantes.

Assim como a "mulher", - entendida como categoria teórica/ tipologia de personagem -, o "tolo" encontra-se igualmente harmonizado com a "vida social" [ou vida exterior]. Isso significa dizer que esta última não é fonte de perturbação para ele; pelo contrário, o "tolo" tira proveito da "vida social" para levar à frente, sem maiores constrangimentos, seus projetos - sejam afetivos, profissionais, etc [perspectiva estratégica]. Citemos uma passagem de "Queda que as mulheres têm pelos tolos":

[O "tolo"] (t)em uma coleção de cartas prontas para todos os graus de paixão (...). As suas fórmulas são enfáticas e chatas; nada que indique uma personalidade. Não faz suspeitar excentricidade ou poesia; é quanto basta; é medíocre e ridículo, tanto melhor (Maia Neto, 2007, p.41) ${ }^{36}$

Segundo propõe o autor, os "tolos" seriam os precursores dos "medalhões" da segunda fase - dos quais “Teoria do Medalhão" é o conto paradigma.

Seja como for, essa relação com a vida exterior (no mais harmônica e em nada ressentida) que concerne tanto à personagem feminina como ao tolomedalhão não corresponde à orientação do "homem de espírito". Na medida em que este acredita na existência de uma verdade, eticidade, ou valor moral perene por trás das aparências conflitantes, sua relação com a vida exterior é eminentemente conturbada.

\footnotetext{
${ }^{36}$ Citação retirada por José Raimundo Maia Neto de: MACHADO DE ASSIS, Joaquim Maria. Obra Completa, 3 Vols. Organizada por Afrânio Coutinho. Rio de Janeiro: Editora José Aguilar, 1962.
} 
Os homens de espírito fracassam porque não se coadunam com os padrões de interesse e conversação sociais das mulheres (os 'divertimentos' sociais que Pascal denuncia por desviarem a atenção do ser humano de sua própria miséria) (...). (Maia Neto, 2007, p.39).

É precisamente nessa categoria de personagem que José Raimundo Maia Neto investe para levar a cabo sua tese.

Em trecho citado acima, grifei duas palavras: gestação e evolução da perspectiva cética. Essas duas palavras são importantes, pelo fato de, para o autor de $O$ ceticismo na obra de Machado de Assis, corresponderem às duas fases da ficção machadiana ${ }^{37}$ que, por sua vez, encontram-se relacionadas às perspectivas possíveis adotadas pelo "homem de espírito" (e, consequentemente, aos destinos ficcionais que lhes cabem, como se verá adiante) ${ }^{38}$.

- Primeira fase (gestação da perspectiva cética). Na fase de gestação, que compreende os primeiros contos e romances anteriores à publicação de Memórias Póstumas de Brás Cubas, o "homem de espírito" possui duas perspectivas possíveis: a perspectiva ingênua e a perspectiva problemática.

Tal se dá pelo seguinte estado de coisas: segundo Maia Neto, nas narrativas

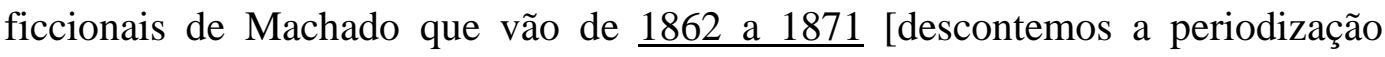
excessivamente rígida do autor], ainda há a possibilidade de união conjugal entre "mulher" e "homem de espírito". Isso quer dizer que, aqui, algumas personagens femininas preferem estes últimos aos "tolos". Do mesmo modo, o casamento ainda se apresenta como alternativa possível à corrupção da vida exterior e suas aparências - o que faz com que o "homem de espírito" possa sustentar uma perspectiva ingênua: casar-se, para ele, significa se afastar das agitações e perturbações causadas pela vida em sociedade e conciliar-se com os valores morais perenes e com a verdade [paz doméstica].

A partir de 1871 , contudo, o mesmo já não se dá, uma vez que a vida conjugal, absorvida pelos reclames da vida exterior, deixa de se apresentar como alternativa possível; do mesmo modo, cada vez menos há personagens femininas que preferem os "homens de espírito" aos "tolos":

\footnotetext{
${ }^{37}$ Em relação a esse tópico, o filósofo segue as orientações da crítica literária tradicional, que divide a obra de Machado de Assis em duas fases.

38 A palavra perspectiva, aqui, embora não contradiga a noção de perspectivismo trabalhada no capítulo anterior, está empregada na acepção comum e não como termo técnico.
} 
As condições para a crise cética que marca o início da segunda fase começa a se constituir nos contos a partir de 1871, quando o número de mulheres estratégicas supera o número das "mulheres de espírito" e o casamento torna-se parte dessa mesma vida social negativa. Assim o que era paz doméstica torna-se parte da vida exterior. As falsas aparências da última corrompem a verdade e eticidade da primeira (Maia Neto, 2007, p. 42).

Desfeita a possibilidade de paz doméstica, resta ao "homem de espírito" a perspectiva problemática: desiludido com as "falsas aparências" da vida social e parte perdedora na relação triangulada que se estrutura entre ele, a personagem feminina e o "tolo" ${ }^{39}$, não lhe resta outra coisa senão o suicídio, a loucura ou o desvario.

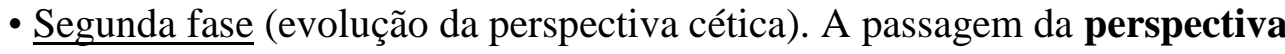
problemática para a perspectiva cética propriamente dita, segundo José Raimundo Maia Neto, dá-se devido ao impasse, - espécie de não lugar ficcional [morte ou loucura], - que resta ao "homem de espírito" nas narrativas machadianas da primeira fase.

Daí a solução formal que, segundo o filósofo, Machado de Assis teria encontrado para suas narrativas ficcionais: conferir a esses "homens de espírito" a condição de autores de memórias e memoriais.

Assim, Brás Cubas, D. Casmurro e Aires tornam-se observadores céticos tout court (adotando, a rigor, a perspectiva cética inacessível aos personagens da fase anterior) na medida em que se tornam narradores-autores em primeira pessoa.

Além disso, as etapas do percurso cético, - zetesis (investigação), epoche (suspensão do juízo) e ataraxia (tranquilidade), - são relacionadas, respectivamente, a Memórias Póstumas, Dom Casmurro e Memorial de Aires. Esse é o motivo de a segunda fase da ficção machadiana corresponder a uma evolução: se por um lado Brás Cubas e Dom Casmurro assumem a perspectiva cética, por outro lado somente o conselheiro Aires chegará à ataraxia, ao adotar, com sucesso, a atitude "estético-cognitiva" (Maia Neto, 2007, p.22) em relação à personagem feminina e à vida exterior.

\footnotetext{
39 “Todos os romances de Machado e a maioria de seus contos são estruturados por um triângulo amoroso: uma mulher e dois homens que exibem perspectivas opostas. Por um lado, há o tolo (primeira fase) ou medalhão (segunda fase) que adota a perspectiva estratégica. Por outro lado há o homem de espírito que adota a perspectiva ingênua (...)" (MAIA NETO, 2007, p. 25).
} 
Em suma: para sustentar sua argumentação, o autor de $O$ ceticismo na obra de Machado de Assis vale-se das seguintes estratégias:

- Apóia-se nas categorias/tipologias rígidas de "personagem feminina", "tolo" e "homem de espírito", investindo na triangulação amorosa como único critério para discutir essas personagens.

- Lança mão de contos e romances para argumentar a favor da gestação da perspectiva cética, mas somente de romances para argumentar a favor da evolução dessa perspectiva.

- Defende a ideia de que a condição de memorialista (no caso, através de narradores em primeira pessoa a fazerem anotações sobre a própria história) é indispensável para que se pense a filosofia de Machado de Assis: no caso, uma filosofia eminentemente cética que completa todas as etapas do pirronismo: zetesis, epoche e ataraxia.

Em relação a esses tópicos, façamos algumas considerações.

\begin{abstract}
$* * *$
Quanto ao primeiro ponto, creio que a tipologia "personagem feminina", "tolo" e "homem de espírito" seja excessivamente categórica. O próprio conselheiro Aires, que seria o personagem cético por excelência, segundo os esquemas de $O$ ceticismo na obra de Machado de Assis, teria lançado mão do casamento devido ao fato de que a condição social de casado convinha mais à sua carreira de diplomata que a condição de celibatário. Cite-se passagem de Esaú e
\end{abstract} Jacó referida em nota pelo próprio autor:

Posto que viúvo, Aires não foi propriamente casado. Não amava o casamento. Casou por necessidade de ofício; cuidou que era melhor ser diplomata casado que solteiro (...) (Maia Neto, 2007, p. 163)

Ou seja: se por um lado Aires não é um típico "medalhão", por outro lado não deixa de lançar mão de uma estratégia (e não se trata de pequena estratégia) 
para, aos olhos da opinião, ser bem visto (e talvez ascender) na carreira diplomática... ${ }^{40}$

Nosso cônego Matias, do mesmo modo, só aceita escrever o sermão por encomenda após ver seu nome impresso nos jornais, qualificando-o a ele como "um dos ornamentos do clero brasileiro" (Assis, 2008, p. 529). O mesmo se dá com Macedo, o ornitologista de "Ideias de canário", que lograva "assombrar o século" (Assis, 2008, p.569) - tal qual Brás com a invenção do emplasto - com suas descobertas. Seriam Matias e Macedo simples "tolos" / "medalhões" em busca de nomeada? Não é o que me parece.

Enfim, apesar de discordar da separação demasiado rígida entre as três categorias, penso que a de "homem de espírito", particularmente, possa nos ser útil - embora em direção distinta da de Maia Neto.

Parece-me que o autor de $O$ ceticismo na obra de Machado de Assis aposta demais na categoria em questão, quando, na verdade, penso que ela seja precisamente a categoria da qual é preciso desconfiar. Digo isso pelo seguinte motivo: embora sugira que os céticos de Machado "não são filósofos no sentido estrito” (Maia Neto, 2007, p. 19), José Raimundo Maia Neto os toma como tal (sobretudo no que diz respeito aos personagens-autores da segunda fase). E, fazendo-o, usa-os como ilustração para a filosofia cética que quer defender/demonstrar como sendo a filosofia de Machado de Assis (quando este, a rigor, não é filósofo, mas ficcionista: seus problemas se dão no texto, na linguagem artística que, materializando sensações, evidencia o trabalho do pensamento).

Em outras palavras: embora sublinhe a "relevância da forma literária" (Maia Neto, 2007, p. 23) no contexto de sua discussão, o autor limita essa forma literária à adoção, por parte dos "homens de espírito", da condição de personagensnarradores em primeira pessoa. Esse motivo, aliás, faz com que exclua Quincas Borba, que é escrito em terceira pessoa, de sua malha argumentativa.

Se lembrarmo-nos dos contos trabalhados na presente dissertação, veremos que nenhum dos dois é construído com personagens-autores: "O cônego ou metafísica do estilo" é narrado em terceira pessoa (uma estranha terceira pessoa

\footnotetext{
${ }^{40}$ No romance em questão (Esaú e Jacó), o personagem já se encontra aposentado, de modo que essa é uma informação que diz respeito ao seu passado.
} 
que, além de fazer intervenções metaficcionais ${ }^{41}$, faz, ainda, propostas absurdas com alcance epistemológico); e "Ideias de canário" é narrado em terceira e primeira pessoa - sem que esta, contudo, assuma a posição de narrador-autor de memórias.

Creio, ainda, que Matias e Macedo, além de não serem “tolos”, são, pelo contrário, "homens de espírito". E aqui marco o ponto em que penso que seja possível aproveitar essa categoria de maneira distinta da aproveitada por José Raimundo Maia Neto: "homem de espírito" é o cônego Matias interrogando a Natureza (valor-gênio) em busca de inspiração para seu sermão; é o ornitologista Macedo que, obsessivamente, logra alfabetar a língua do canário no afã de descobrir-lhe tanto os segredos quanto a definição do mundo; é o músico Pestana que, consumindo-se perante os retratos de Mozart e Beethoven, insiste em compor uma obra genial, imortal, transcendental - quando seu Genius, a cada momento, oferece-lhe "vida", "graça" e "novidade" (Assis, 2008, p. 466) através da composição de polcas amaxixadas ${ }^{42}$.

O "homem de espírito", a meu ver, seria o excêntrico por excelência; aquele que, mediante crenças e empenhos os mais diversos, busca encontrar a substância de um objeto dado: da ciência, da alma, da arte - Macedo (figura da qual " $O$ Alienista" é o conto-paradigma), Matias, Pestana. Todos eles seriam, para usarmos a expressão nietzschiana, homens de espírito afetados irrevogavelmente por "vontade de verdade".

Escusado dizer que a "forma literária" que problematiza essas personagens não se limita a narradores-memorialistas em primeira pessoa. Cada um dos textos mencionados acima possui sua estratégia própria. Em "O cônego", trata-se de subir à cabeça do padre Matias para, de dentro desta, problematizar-lhe o valortrabalho e o valor-gênio através do elemento incontrolável próprio ao corpo; em "Ideias de canário", trata-se de conferir voz ao animal (investindo-se no dado sonoro-sensitivo) para desconstruir o funcionamento lógico-racional (valortrabalho) do pensamento científico; em "Um homem célebre", trata-se de, a partir da observação do que em Pestana é empenho consciente, valorizar a potência corporal-inconsciente que, no entanto, o assombra.

\footnotetext{
${ }^{41}$ Sobre as intervenções dos narradores machadianos, que quebram constantemente a ilusão de realidade cara à prosa realista/representativa, tomo como referência a dissertação de Mestrado de Raquel Peralva Martins de Oliveira: Machado de Assis: "o crítico dos outros e de si próprio".

${ }^{42}$ Comentarei, mais adiante, o conto "Um homem célebre".
} 
A esse respeito, gostaria de retomar uma noção que trabalhei ao final do segundo capítulo da presente dissertação: a noção de estilo de escrita. Isso porque, embora possuindo alcances epistemológicos semelhantes, ou seja, discutir o sensitivo e o corporal como instâncias desierarquizadoras da razão e do logos, cada conto é um conto - dotado, portanto, de lógica e estratégias próprias.

Nesse sentido, eles são irrepetíveis (não são textos de "escrevência") ao mesmo tempo em que são repetíveis (e efetivamente se repetem como gesto que, manifestando-se de modos diferentes, chegam a caminhos investigativo-ficcionais semelhantes). É o que nos diz Roberto Corrêa dos Santos em passagem fundamental de seu ensaio-fragmento sobre Machado:

A diversidade nasce do impulso sempre igual, da soberania e grandeza de ser este e não outro (...). Criar, apesar e por causa do estilo, consiste em uma espécie de tolerância para consigo mesmo, um curvar-se ante a inevitabilidade do gesto repetido. A obsessão, um dos móveis do estilo, ao invés de imobilizar reagindo, afirma-se agindo. Só assim torna-se o estilo uma vontade, refina-se. E o que é refinar o estilo? Tornar a brutalidade de ser o que se é uma força (Santos, 1999, p. 85).

Embora de maneira não frontal, penso que essas considerações tenham dado conta, em certa medida, do segundo e terceiro pontos mencionados acima acerca das estratégias argumentativas de José Raimundo Maia Neto: a não exploração dos contos da segunda fase de Machado de Assis como ilustradores da perspectiva cética, e a redução da "forma literária" de Machado, em nome da mesma perspectiva cética, ao problema do narrador-autor em primeira pessoa ${ }^{43}$.

Tendo isso em vista, entendo que: a atitude das personagens machadianas e os traços estilísticos da escrita em que se materializam correspondem, a sua maneira, à etapa da "suspensão do juízo" no método do ceticismo. Ao deslocarem sua busca de conhecimento para seres de outras espécies ou situações fantásticas, os personagens-investigadores estariam desqualificando a verdade (tal como compreendida pelos "dogmáticos") e, assim, levando o estilo narrativo a assumir as formulações/construções paradoxais. O objetivo visado, portanto, não é atingir a ataraxia, ainda que se possa perceber simpatia por tal estado em determinadas

\footnotetext{
${ }^{43}$ No que diz respeito a esse tópico, cf. MARINATO, Ana Carla Lima: Autor, narrador, personagem: as várias facetas dos Aires de Machado. Dissertação de Mestrado. Vitória, UFES: 2013.
} 
personagens. Assim, em lugar desta etapa do pensamento cético, a escrita machadiana faz-se "intransitiva", resistindo tanto à tomada de posições moralistas/moralizantes quanto ao engajamento num realismo substancialista/ programático.

Em suma: apesar de discordar da maneira como O ceticismo na obra de Machado de Assis aproxima/pensa as relações entre o escritor fluminense e a filosofia cética, penso que, ainda assim, valha a pena observar, via tropoi (ou modos céticos), alguns aspectos desta última - uma vez que ela indica caminhos com os quais a ficção machadiana possui (relativa) afinidade, afastando-se através de variadas estratégias escriturais -, assim, da linha filosófica platônicoaristotélica historicamente triunfante.

Dentre as obras dos pirrônicos antigos, a única que sobreviveu foi a de Sexto Empírico (início do século III d.c), que passou então a exercer forte influência na filosofia renascentista e moderna. Eis o que diz os Esboços do pirronismo, de Sexto, que apresentam "uma visão abrangente e sistemática do pirronismo antigo", definindo-o como:

Uma habilidade ou atitude mental que contrapõe aparências e juízos com o resultado de, devido a eqüipolência dos objetos e razões assim contrapostas, sermos levados, primeiro, a um estado de suspensão mental e em seguida a um estado de imperturbabilidade ou quietude (Maia Neto, 2007, p.15).

De saída, observemos, via Maia Neto, aspectos concernentes ao pirronismo antigo.

Antes de tudo, diga-se que o pirronismo configura-se como uma "habilidade", e não como um sistema filosófico articulado através do qual se chegaria ao conhecimento. Isso não significa dizer, entretanto, que para o pirrônico o conhecimento seja considerado inatingível. Antes, diga-se que sua habilidade consiste em examinar, através de práticas argumentativas, "qualquer doutrina adotada por pensadores dogmáticos" acerca da "natureza das coisas" (idem). Interessante notar, a esse respeito, que tão logo essa ou aquela doutrina é 
refutada, os argumentos que lhe serviram de base para tal operação são igualmente deixados de lado - uma vez que, no mais, se mostram tão persuasivos quanto a(s) doutrina(s) em questão (equipolência).

A trajetória do pirrônico difere da do dogmático pelo fato de sua investigação (zetesis) não levá-lo a uma doutrina, mas a uma equipolência. Incapaz de escolher entre uma doutrina e sua contrária, o pirrônico suspende o juízo (epoche) e inesperadamente alcança a tranqüilidade (ataraxia) que inicialmente pensava encontrar na descoberta da verdade (Maia Neto, 2007, p. 16).

Assim como para os dogmáticos, o ponto de partida do pirrônico é a perturbação causada por "aparências conflitantes" (Idem), o que faz com que ambos, com o intuito de alcançar a tranquilidade (ataraxia), iniciem uma investigação (zetesis) em relação à natureza da coisa que os perturba/agita.

Como expresso na citação acima, a diferença entre os dois está no fato - e esse é um ponto importante - de que o dogmático tranqüiliza-se ao chegar àquilo que ele "pensa ser a verdadeira natureza da coisa" (idem. grifo meu), ao passo que o pirrônico apenas constata que essa tranquilidade atingida é na verdade fruto de avaliações precipitadas, as quais, por sua vez, não resistem a exames de fato rigorosos: ou a explicação do dogmático não é totalmente satisfatória; ou outras teorias podem explicar as aparências em questão de modo a chegar a resultados diversos; ou, finalmente, determinados argumentos ignorados pelo dogmático podem tornar inoperantes suas explicações.

Nesse sentido, note-se que, no que diz respeito ao exame das aparências, a prática argumentativa utilizada pelo pirrônico leva em consideração a ideia de que os objetos estão sempre sujeitos a múltiplos pontos de vista de apreciação.

Se por um lado essa prática argumentativa não chega a ser tão radical quanto o projeto nietzschiano de transvaloração de todos os valores, por outro lado ela se aproxima, em certa medida, da noção de perspectivismo, uma vez que leva em consideração o problema do olhar - o qual, para o pirrônico, possui potência suficiente para neutralizar a "vontade de verdade" a partir da qual o pensador dogmático almeja chegar à ataraxia . 
No tocante aos "principais argumentos usados pelos pirrônicos em seu exame dos dogmas filosóficos", José Raimundo Maia Neto (via Sexto Empírico) mostra que eles foram classificados em vários modos ou tropoi.

Sexto lista um conjunto de modos supostamente sistematizados pelo pirrônico Enesidemo (primeiro século AC) e um outro sistematizado por um segundo discípulo de Pirro, Agripa (primeiro século DC) (Maia Neto, 2007, p. 17).

Com o intuito de destacar alguns deles, vejamo-los resumidamente. Para tanto, listemos os dez modos de Enesidemo, que consistem no seguinte:

$\mathbf{1}^{\circ}$ - Tomar o ser humano como único ser capaz de "apreender a verdadeira natureza das coisas" seria uma grande e injustificada pretensão, uma vez que os "órgãos dos sentidos" através dos quais a realidade é captada variam segundo as múltiplas espécies de animais ${ }^{44}$ (Maia Neto, 2007, p.17).

$\mathbf{2}^{\circ}$ - Os “órgãos dos sentidos" variam, também, entre os próprios humanos segundo suas características naturais e/ou cognitivas, o que torna absurda a presunção dos dogmáticos, - no que diz respeito ao ato de julgamento das coisas, - de preferirem a si mesmo às outras pessoas (idem).

$\mathbf{3}^{\circ}$ - Os sentidos de um mesmo ser/pessoa podem fornecer informações "contraditórias" em relação a um mesmo objeto: "Como então decidir qual conclusão é verdadeira?” (idem).

$4^{\circ}$ - Diz respeito às mais diversas circunstâncias que, interferindo na “percepção sensível”, afetam o julgamento: “(...) disposições de humor ou condições corporais (tais como idade)", "estados mentais (tais como sonho ou vigília)" 45 (idem) etc.

$5^{\circ}$ - Trata da impossibilidade de se fazerem asserções peremptórias sobre a natureza dos objetos, uma vez que "objetos estão sempre localizados em um lugar e posição particular" - o que faz com que as avaliações variem segundo variam os pontos de vista de observação ${ }^{46}$ (Maia Neto, 2007, p.18).

\footnotetext{
${ }^{44}$ Em certa medida, "Ideias de Canário" seria uma radicalização, via ficção, desse primeiro modo. Cf. capítulo 4.

45 "Nunca pude entender a conversação que tive com uma senhora, há muitos anos, contava eu dezessete, ela trinta" (ASSIS, 2008: 562. grifo meu) - famosa frase de Nogueira, de "Missa do Galo", conto no qual a dimensão onírica possui papel digno de nota.

${ }^{46}$ Lembre-se que em "O cônego ou metafísica do estilo", o Corcovado e o Himalaia não são altos em si -segundo adverte o narrador do conto, a cabeça do "leitor" é que os mede... Este último,
} 
$6^{\circ}$ - Uma vez que os objetos são percebidos através de algum meio ou misturados com outros objetos, é impossível saber se o que se percebe é ele mesmo ou sua mistura com outros.

$7^{\circ}$ - Baseia-se na constituição e na quantidade do objeto: a depender da quantidade consumida de tal alimento, por exemplo, seus efeitos mudam para quem o ingere. $\mathrm{O}$ conhecimento a respeito da natureza desse alimento, portanto, é inseparável de seus efeitos.

$\mathbf{8}^{\circ}$ - Versa sobre a relatividade das coisas: uma vez que estas são sempre relativas, suspende-se o juízo sobre o que elas seriam de fato.

$9^{\circ}$ - Diz respeito à constância ou raridade da ocorrência das coisas: se o diamante passa a se tornar abundante no mundo, não há que se supor que ele vá continuar a ser uma pedra preciosa.

$\mathbf{1 0}^{\circ}$ - Concerne às opiniões, leis e costumes: tendo em vista que estes "variam e entram em conflito" consoante o tempo e o espaço nos quais se inserem, não se pode emitir julgamentos sobre quais deles seriam os melhores e/ou verdadeiros.

Embora minha intenção, como proposto acima, não seja me demorar nos modos ou tropoi de Enesidemo, volto a atenção, por ora, ao $4^{\circ}$ e ao $10^{\circ}$. Para tanto, tomo como referência complementar a dissertação de Mestrado de Claudia Fernanda Chigres (1995) - A cura pela palavra: Os ensaios de Montaigne e as lembranças de Tocqueville.

Ao tecer considerações sobre as "circunstâncias", tópico que concerne ao quarto modo, a autora mostra que o alvo de Enesidemo "recai sobre os chamados discursos téticos, nos quais os objetos são percebidos fora de qualquer circunstância" (Chigres, 1995, p. 39).

Assim, se por um lado o exame de determinado objeto "faz parte do jogo das representações", por outro lado "dizer como ele é seria absurdo, pois aquele que julga saber como ele realmente é, (sic) certamente se encontra em alguma situação, posição ou condição" (idem. grifo meu). Ou seja: aquele que julga é 
sempre parte constituinte da diaphonía ${ }^{47}$ - motivo pelo qual não pode arrogar para si mesmo a condição de juiz.

Ao lado das "circunstâncias" que, segundo Maia Neto, envolvem as disposições de humor e/ou as condições corporais, Claudia Chigres toca num ponto suplementar, a saber, o de que,

Tomando os objetos por culturas ou sociedades, devemos estar conscientes de que somos sujeitos de conhecimento e estamos constrangidos por circunstâncias ou valores culturais (...). Os conceitos de cultura e de valor, tão caros a Max Weber, por exemplo, remetem para esta dimensão circunstancial, pois como diz, o fenômeno estaria 'condicionado pela orientação do nosso interesse de conhecimento, e essa orientação define-se conforme o significado cultural que atribuímos ao evento em questão em cada caso particular' (Chigres, 1995, p. 3940).

Essa "dimensão circustancial" que concerne aos conceitos de cultura e de valor nos parece relevante por dois motivos. Em primeiro lugar, ela se encontra presente, também, na genealogia e no perspectivismo de Nietzsche - cujo propósito (entre outros) consiste em investigar de que maneira e em que condições os valores são construídos, histórica e culturalmente, no seio do embate de forças que se dá entre os corpos.

A esse respeito, diz-nos Michel Foucault (1979) em "Nietzsche, a genealogia e a história", mostrando o porquê da recusa do filósofo alemão, em determinadas ocasiões, diante da pesquisa da "origem":

Porque, primeiramente, a pesquisa, nesse sentido, se esforça para recolher nela a essência exata da coisa, sua mais pura possibilidade, sua identidade cuidadosamente recolhida em si mesma, sua forma imóvel e anterior a tudo o que é externo, acidental, sucessivo (Foucault, 1979, p. 17).

Segundo Foucault, a lição que o genealogista aprende ao se voltar para a história (e não para a metafísica) consiste em perceber que: "o que se encontra no começo histórico das coisas não é a identidade ainda preservada da origem - é a discórdia entre as coisas, é o disparate" (Foucault, 1979, p. 18).

\footnotetext{
47 "Dado que as opiniões acerca do mundo fenomênico são diversas e variadas, é natural que haja discordância de posições a respeito delas. Esta manifesta discordância é denominada diaphonía" (CHIGRES, 1995, p.33).
} 
Seja qual for sua figura, o fato é que por trás da noção de valor há sempre algo que se mexe, vive, pulsa - e concorre para sua criação. Nesse contexto, note-se que a noção de perspectivismo (que apresenta alguma proximidade com tópicos do pirronismo) não resulta, de modo algum, em mero relativismo: antes, faz parte de uma dinâmica cujo funcionamento se encontra relacionado ao trabalho genealógico de pesquisa e à transvaloração dos valores.

Embora não possuindo, naturalmente, nem esses propósitos nem essa radicalidade, o quarto modo de Enesidemo combate, como vimos acima, os chamados discursos téticos. Isto é, aqueles que ignoram a dimensão circunstancial que envolve todo objeto: e eis que passamos ao décimo modo de Enesidemo e ao segundo motivo que me faz grifar a expressão acima.

Segundo a autora, esse décimo modo ou tropoi "diz respeito à ética, e baseia-se em regras de conduta, leis, crenças derivadas de lendas e concepções dogmáticas. É o Modo dos costumes e persuasões" (Chigres, 1995, p. 44. grifo meu). Ou melhor, o modo que vai de encontro à lógica dos costumes e persuasões. Dado o "axioma cosmopolita e anti-etnocêntrico" ${ }^{48}$ que o configura, ele potencializa a ideia geral explorada ao longo dos outros modos: a de que "não há como se obter consenso a respeito de qualquer uma das dimensões do mundo, pois a nenhuma delas é possível creditar a verdade das coisas" (idem).

No tocante ao último modo de Enesidemo, Sexto Empírico definiu cinco itens que, entrando em contradição (diaphonía) com exemplos extraídos do mundo fenomênico, ter-se-iam tornado inoperantes devido à equipolência então detectada. Cito apenas dois deles, com o único intuito de ilustrar seu caráter predominantemente dogmático:

2. As leis são definidas como contratos escritos entre membros de um Estado, com características coercitivas, inclusive com punição dos desobedientes.

5. As Concepções Dogmáticas são mencionadas como aquelas cuja aceitação de fatos tem caráter não-evidente, estabelecidos ou por analogia, ou por demonstrações (Chigres, 1995, p. 45).

\footnotetext{
${ }^{48}$ LESSA, Renato. apud CHIGRES, 1995, p.44.
} 
Seja como for, à equipolência verificada segue-se a suspensão do juízo que, segundo mostra Claudia Chigres, "teria como corolário a ideia de relatividade cultural" (idem).

No limite, se encontramo-nos "constrangidos por circunstâncias e valores culturais", os quais, por sua vez, nos tornam sujeitos de conhecimento (conforme sugerido em citação acima), não será exagero dizer que essa ou aquela disposição de humor, essa ou aquela condição corporal podem estar ancoradas, por vezes, em modos de existência que, no mais, resultam em maneiras peculiares de se olhar para o mundo e para as coisas.

Ao final de "Um homem célebre" ${ }^{49}$, o protagonista Pestana vem a falecer, segundo nos conta o narrador, de bem com os homens e de mal consigo mesmo.

Compositor de talento (e de talento reconhecido pelo público), o drama pessoal que atravessa sua vida é não conseguir compor, - seja mediante esforço diário e valor-trabalho, seja mediante inspiração e valor-gênio, - uma única música "ao sabor clássico" (Assis, 2008, p. 467), ao passo que as saltitantes e populares polcas de salão saem-lhe dos dedos, quando ao piano, com toda a facilidade e genialidade possíveis [genialidade, aqui, entendida no sentido de Genius, como se verá adiante].

Para falarmos com Roberto Corrêa dos Santos, pode-se dizer que Pestana não é / não foi capaz de transformar a brutalidade do "ser o que se é" (Santos, 1999, p. 85. grifo meu) em força ativa a serviço da vida: se por um lado suas composições causam forte impressão junto ao público, - e se, no momento mesmo em que as compõe, o músico desrecalca-se do drama fatal que o persegue, - por outro lado elas não são motivo de afirmação, mas de sofrimento: a "disposição de humor" de Pestana, na qualidade de "circunstância" ( $4^{\circ}$ modo de Enesidemo) que filtra seu olhar e afeta-lhe a "percepção sensível”, faz dele, antes de tudo, um ressentido.

Trocando em miúdos: artisticamente e como motor corporal do estilo, as polcas se realizam (uma vez compostas, circulam como dado positivo e coletivo

\footnotetext{
${ }^{49}$ Conto publicado por Machado de Assis na Gazeta de Notícias e reunido, posteriormente, em Várias Histórias.
} 
entre o público); afetivamente e como motor vital para o próprio compositor, contudo, elas não se realizam. Em Pestana, portanto, vida e estilo (e, por extensão, vida e escrita, vida e corpo), encontram-se fatal e contundentemente apartados: a realização não realiza - para usarmos uma expressão lapidar de José Miguel Wisnik (2004).

Para fazer as ligações sugeridas acima acerca dos modos céticos de Enesidemo, eu diria que o ressentimento do compositor, além de condicionado pelo $4^{\circ}$ modo, encontra-se arraigado, também, no $10^{\circ}$, o qual diz respeito, como observamos via Claudia Chigres (1995), à ética relativa aos costumes e persuasões - e, por extensão, às noções de valor e de cultura.

Trata-se, em suma, do "complexo de Pestana" (Wisnik, 2004, p. 104. grifo meu) desenhado por José Miguel Wisnik em "Machado maxixe"; complexo esse cujo multiculturalismo inerente à música popular brasileira predominantemente mestiça opõe resistência. E, assim fazendo, deixa em suspenso o juízo em relação tanto à validade da concepção idealista do fazer artístico como à superioridade da arte erudita sobre a popular.

Em "Machado maxixe", José Miguel Wisnik propõe que o tormento de Pestana, protagonista de "Um homem célebre", em muito ultrapassa o do músico que, desprovido de capacidade inventiva, é incapaz, apesar de todos os esforços, de ultrapassar a condição de mero intérprete: Pestana, ao contrário de Mestre Romão ${ }^{50}$, é compositor profícuo.

Em direção semelhante, seria redutora (além de preconceituosa) uma leitura do conto que investisse no tema do compositor popular que, devido a (supostas) limitações técnico-inventivas impostas por tal condição, fosse incapaz de compor música clássica.

Assim é que, segundo o ensaísta, "Um homem célebre” possuiria implicações e alcance analítico (bem) mais complexos. Sem pretender dar conta das inúmeras nuances do ensaio em questão, recortemos os pontos que mais diretamente nos interessam, buscando relacioná-los, na medida do possível, ao $4^{\circ}$

\footnotetext{
${ }^{50}$ Personagem de "Cantiga de Esponsais", que, embora seja ótimo regente de músicas alheias, é incapaz de compor as suas próprias.
} 
e $10^{\circ}$ modo de Enesidemo tratados acima. Como ponto de partida, cite-se uma passagem de "Machado maxixe":

Pestana, célebre nos saraus, salões, bailes e ruas do Rio de Janeiro por suas composições irresistivelmente dançantes, esconde-se dos rumores à sua volta num quarto povoado de ícones da grande música europeia, mergulha nas sonatas do classicismo vienense, prepara-se para o supremo salto criativo, e, quando dá por si, é o autor de mais uma inelutável e saltitante polca (Wisnik, 2004, p. 17. grifo meu).

Façamo-nos as seguintes perguntas: o que, exatamente, faz com que a “disposição de humor" (Maia Neto, 2007, p. 17) de Pestana, embora oscilante ${ }^{51}$ até certo ponto de sua vida, tenda, inequivocamente, ao dado reativo? Dizendo de outro modo: para além da incapacidade fatal de compor peças musicais "ao sabor clássico" (Assis, 2008, p. 467), por que motivo os rumores à sua volta, ou seja, as aparências da vida exterior o incomodam tanto?

Dentro desse contexto, qual será a função da música popular, - enquanto materialização do pensamento argumentativo-ficcional machadiano -, no enredo desse conto em que os "ícones da grande música europeia", se por um lado não se configuram apenas como objetos-fetiche fixados na parede do compositor, por outro lado em nada concorrem para o entendimento da vida como força afirmativa?

Intermezzo:

Com o intuito de estabelecer uma constelação crítico-ficcional em torno do elemento sonoro em Machado, destaco elementos condensados de: "Conto de escola"; "A ópera" (capítulo IX de Dom Casmurro); e "Inexplicável” (capítulo XXXIV de Esaú e Jacó).

\footnotetext{
${ }^{51}$ Nos momentos fugazes em que compunha suas polcas, sem esforços e esquecendo-se de si mesmo, todo o ressentimento resultante de suas incursões frustradas no terreno da música clássica se esvaía; e não só isso: ao longo de alguns dias o compositor, enamorado de suas criações, sentiase até mesmo feliz e eufórico. Esse estado de coisas só muda ao final de sua vida, quando, completamente desiludido, tanto a alegria como a tristeza deixam de se apresentar como sentimentos extremados.
} 


\section{- "Conto de escola":}

A escola é um "sobradinho de grade e de pau". O professor é "um velho empregado do arsenal de guerra, ríspido e intolerante". A palmatória, pendente do portal da janela, exibe seus "cinco olhos do diabo".

Entre dois meninos - um deles com dificuldades nos estudos -, se dá um contrato-corrupção: o que possui dificuldades oferece ao outro uma "moeda do tempo do rei” em troca de ajuda com a lição de sintaxe.

Ao canto da sala, um terceiro menino, inquieto, observa a transação proibida. Este último denuncia os outros dois ao professor. Entre golpes de palmatória e impropérios, dá-se a punição física e moral: "Porcalhões! tratantes! faltos de brio! - brada o mestre, que atira a pratinha pela janela.

Dia seguinte. Na esperança de encontrar a moeda atirada à rua, o menino que ensinou em troca de dinheiro sai mais cedo de casa. Ele traz no espírito as impressões dos valores morais com os quais travara contato no dia anterior: corrupção e delação.

Eis que passa na rua, inesperadamente, uma "companhia do batalhão de fuzileiros, tambor à frente, rufando (...)".

Ao som do rufo, ele entra a marchar e se esquece de tudo. Nesse dia, não vai à escola: passa a manhã vadiando na praia da Gamboa. E volta para casa "com as calças enxovalhadas, sem pratinha no bolso nem ressentimento na alma".

Entre os dois valores morais e a música do batalhão de fuzileiros, ergue-se o elemento paradoxal: "E contudo a pratinha era bonita e foram eles, Raimundo e Curvelo, que me deram o primeiro conhecimento, um da corrupção, outro da delação; mas o diabo do tambor... (Assis, 2008, p. 510-515. grifo meu).

\section{- "A ópera":}

Após um gole de licor, Marcolini, um "velho tenor italiano desempregado" ${ }^{52}$, expõe a Santiago a história da criação. Nesta, "Deus é o poeta. A música é de Satanás (...)". De gênio "essencialmente trágico", este último é expulso do conservatório do céu, do qual sai não sem antes levar um libreto escrito por Deus.

No inferno, compõe a partitura e, uma vez terminada, leva-a ao "Padre Eterno" propondo-lhe parceria. Este, naturalmente, não aceita. Diante das muitas

\footnotetext{
${ }^{52} \mathrm{Cf}$. MOTEIRO, André. "A literatura na ópera da vida".
} 
insistências de Satanás, contudo, acaba consentindo que a obra seja executada desde que fora do céu. Para tanto, ele cria a terra.

Eis alguns dos efeitos estéticos alcançados pela obra: em alguns pontos, "o verso vai para a direita e a música para a esquerda"; e tendo abusado no uso das massas corais, por vezes o maestro (Satanás) acabou "encobrindo muita vez o sentido por um modo confuso" (Assis, 2008, p. 939-940. grifo meu).

\section{• "Inexplicável":}

Diante da afirmação do conselheiro Aires de que Flora seria "inexplicável”, esta, inquieta, exige-lhe esclarecimentos. Eis a definição do conselheiro: "Inexplicável é o nome que podemos dar aos artistas que pintam sem acabar de pintar. Botam tinta, mais tinta, outra tinta, muita tinta, pouca tinta, nova tinta, e nunca lhes parece que a árvore é árvore, nem a choupana, choupana”.

Flora acha a explicação obscura, e diz que, quanto à sua educação pessoal, "tinha a ideia justamente de aprender desenho e pintura" - desde que não fosse para ficar como os artistas de Aires, jogando tinta sem nada pintar: do contrário, preferiria ficar só com a música - que "ia bem com ela" -, o inglês e o francês.

Aires concorda plenamente: "- Pois só a música, o inglês e o francês (...)".

A moça faz prometer ao conselheiro que não seja chamada "inexplicável" novamente. Antes que Aires respondesse, a cena é interrompida pela entrada dos gêmeos Pedro e Paulo ${ }^{53}$.

Nos trechos acima, o dado sonoro, em Machado (mais até do que a música entendida como sistema semiológico articulado), ${ }^{54}$ é investido de potência

\footnotetext{
${ }^{53}$ A resposta de Aires ao pedido da moça - que, se ocorresse, resolveria a tensão ficcional exposta acima -, não se dá ao longo do romance, e Flora permanece "inexplicável" aos olhos do conselheiro. Note-se que o exercício da música em nada perturba tal condição, muito pelo contrário: Aires o incentiva. Vale lembrar que, no enredo do romance em questão, os gêmeos Pedro e Paulo disputam o amor da moça que, no entanto, mantêm-se indecidida entre os dois.

${ }^{54}$ A propósito do capítulo "A ópera", de Machado de Assis, André Monteiro esclarece em que sentido a música constitui-se como instância inerente ao elemento trágico nietzschiano: "Música, nesse caso, não confundida com seu sentido exclusivamente especializado, disciplinar, protocolar (...). Trata-se, de outro modo, de música compreendida como uma experiência de beatitude (...), beatitude como afirmação e entrega ao infinito movimento das forças instáveis (...) que compõem infinitamente a vontade primordial da vida (MONTEIRO, 2010, p. 30-31. grifo meu).
} 
desconstrutora; ou seja, potência suspensiva que leva não a uma tranquilidade, mas a um estado de tensão indecidível - e desierarquizadora do logos como instância privilegiada a partir da qual se veicula todo valor.

Dentre eles, "Conto de escola" talvez seja o caso mais explícito/flagrante ${ }^{55}$ : frente ao rufar dos tambores do batalhão de fuzileiros, corrupção e delação esfumaçam-se aos olhos do menino-narrador, assim como se esfumaça o espaço onde este último travou contato com eles (a escola): após inebriar-se ao som do rufo dos tambores, ao invés de ir à aula o guri prefere passar a manhã na praia da Gamboa - com as "calças enxovalhadas" e "sem ressentimento na alma" (Assis, 2008, p. 515).

Note-se que não se trata, aqui, de mero escapismo ou alienação, mas de choque com o modus operandi de dois valores que, inseridos em um contexto eminentemente coercitivo, no caso específico do conto em questão, alimentam-se e alimentam todo um maquinário institucional (a escola) que supõe, no mínimo, a palmatória brandida arbitrariamente.

Seja como for, me parece que em "Um homem célebre", é a música popular que desempenha, em certo sentido, essa função suspensiva. Diz-nos José Miguel Wisnik:

(...) a impossibilidade de criar sonatas, sinfonias e réquiens, em Pestana, não se resume na incapacidade de compor, mas corresponde a um deslocamento involuntário do impulso criativo em direção à língua comum das polcas, com espantosa força própria, o que faz do compositor não só uma individualidade em crise mas um índice gritante da cultura, um sinal da vida coletiva, um sintoma exemplar de processos que o conto põe em jogo com grande alcance analítico (...) (Wisnik, 2004, p. 19).

Ao mesmo tempo em que o compositor é um "índice gritante da cultura", ele se apresenta como uma "individualidade em crise". Vejamos em que consistem essas linhas argumentativas para, considerando os dois tópicos grifados, destacarmos o ponto que nos interessa: a "disposição de humor" de Pestana ( $4^{\circ}$ modo de Enesidemo) como índice de um complexo de “opiniões, leis

\footnotetext{
${ }^{55}$ Embora a música de Satanás, em "A ópera" - expressão do elemento trágico nietzschiano (cf. André Monteiro) -, não seja menos flagrante: as massas de corais excessivamente carregadas acabam "encobrindo muita vez o sentido por um modo confuso" .
} 
e costumes" ( $10^{\circ}$ modo) do qual, embora sofregamente logre fazer parte, apresenta-se, a cada instante, como uma espécie de coeficiente vazio.

Como ponto de partida, recortemos duas situações ficcionais extraídas - e por nós condensadas - de "Um homem célebre":

- Em sarau íntimo na casa de uma família burguesa, tão logo soam os primeiros compassos de Não bula comigo, nhonhô, derrama-se pela sala "uma alegria nova". Enquanto isso, em outra casa, mais modesta, dança-se ao som de uma "polca festiva" soprada em clarineta - ao mesmo tempo em que, na rua, dos dois homens que passavam, "um deles (...) começou a assobiar a mesma polca, rijamente, com brio, e o outro pegou a tempo na música, e aí foram os dois abaixo, ruidosos e alegres (...)".

- Na sala dos fundos de uma velha casa, imagens de compositores como Beethoven, Bach, Schumann e Mozart, entre outros, pendem da parede "como santos de uma igreja". Um compositor interroga os retratos, as estrelas, o céu, a noite. "Por que não faria ele uma só que fosse daquelas páginas imortais?". De súbito, surge uma ideia. Ele corre ao piano no afã de traduzi-la em sons, mas a ideia esvai-se tão logo pousa os dedos sobre as teclas. Consome-se, assim, a noite inteira. Esgotado e aborrecido, desiste e vai dormir (Assis, 2008, p. 464-466).

De um lado, alegria e realização, de outro, silêncio e não realização. E ainda: de um lado, o devir dos encontros coletivos; de outro, a estaticidade da subjetividade centrada.

Desde já, façamos um esclarecimento. Não se trata, aqui, de se estabelecer uma oposição binário-valorativa entre os conteúdos das passagens acima. Tampouco se trata de inverter, simplesmente, a (hoje desgastada) hierarquização entre música erudita e música popular. Trata-se, ao contrário, de observar em que medida a lógica da primeira passagem configura-se como elemento críticoficcional da lógica da segunda, isto é: o devir da "vida exterior" e da experiência compartilhada, - ou seja, da própria vida entendida como arte ${ }^{56}$, - funcionando

\footnotetext{
${ }^{56}$ Aproprio-me, aqui, do Gilles Deleuze de Conversações.
} 
como dado questionador tanto do centramento subjetivo do indivíduo quanto da Arte na qualidade de instância redentora/transcendental.

Feita essa ressalva,voltemos os olhos para a segunda passagem.

Como observa José Miguel Wisnik, os retratos que figuram na parede de Pestana encontram-se envolvidos em uma "aura de canonização sacral". Beethoven, Mozart e Haydn (para citarmos apenas os compositores cujas sonatas Pestana executa com perfeição ao piano) estão longe de ser, para o nosso compositor, meros objetos-fetiche de "romantismo ralo de salão". Antes, fazem parte da linha prestigiosa e "cheia de consequências" do classicismo vienense que servem, para ele, como parâmetro de valoração estética (Wisnik, 2004, p.58).

Em meio à galeria composta somente por "europeus ilustres”, contudo, há um retrato a óleo que, segundo o ensaísta, possui força de paradigma. Citemos a passagem do conto de Machado referida por Wisnik:

\begin{abstract}
Um só era a óleo, o de um padre, que o educara, que lhe ensinara latim e música, e que, segundo os ociosos, era o próprio pai do Pestana. Certo é que lhe deixou em herança aquela casa velha, e os velhos trastes, ainda do tempo de Pedro I. Compusera alguns motetes o padre, era doudo por música, sacra ou profana, cujo gozo incutiu no moço, ou também lhe transmitiu no sangue, se é que tinham razão as bocas vadias, cousa de que se não ocupa a minha história, como ides ver (Assis, 2008, p. 465).
\end{abstract}

Entre os gigantes da música de concerto europeia, portanto, figura um brasileiro; um padre brasileiro que, tendo educado Pestana, ensinando-lhe música e latim, também era compositor. Aos olhos daquele, portanto, o eclesiástico "não é um humilde músico de igreja, mas está posto na posição de índice das aspirações brasileiras à música de concerto" (Wisnik, 2004, p.58).

Quando "desvairado", "absorto" e "com a alma alhures" executa "com grande perfeição" as sonatas de Haydn, Mozart e Beethoven (Wisnik, 2004, p. 58), a intenção tresloucada do compositor de polcas amaxixadas ${ }^{57}$ tem como

\footnotetext{
${ }^{57}$ No contexto geral de "Machado maxixe", as polcas não se apresentam como dança de salão europeia transposta para os trópicos, mas como elemento transcultural que, tendo adquirido, no Brasil, singularidades rítmico-melódicas, são expressão de todo um imaginário coletivo ligado à "música e à escravidão, à música erudita e à música popular urbana, à música europeia e à africana, à miscigenação e à mestiçagem, tudo isso se combinando na fronteira do emergente com o recalcado" (WISNIK, 2004, p. 75).
} 
mira, portanto, não só os mestres europeus, mas também o brasileiro que, segundo as "bocas vadias", teria sido seu pai sanguíneo.

Entre o dito e o não-dito dos negaceios do narrador, que nem legitimam nem negam a ligação biológica entre os dois músicos, o que está em jogo (e importa mais diretamente à nossa leitura) é a relação paternidade-filiação que, malgrado as tentativas frustradas de Pestana no campo da música erudita, o compositor precisa e quer reconhecer.

Em outras palavras: por trás de suas investidas conscientes e, no mais, esforçadas (valor-trabalho), o que ele quer e precisa alcançar é algo mais substancial, algo mais espiritual, algo mais essencial. Trata-se, enfim, do valorgênio embutido na ideia de paternidade; paternidade essa que, para José Miguel Wisnik, é “inseparável (...) do drama artístico e existencial de Pestana” (Wisnik, 2004, p. 59) - leitmotiv que anima "Um homem célebre":

Está em jogo, na verdade, um cabedal genético-cultural incontornável, investindo de maneira dúbia na dimensão simbólica da paternidade: quando reza por música a sua missa noturna, Pestana busca sair-se dela como o pai de uma obra clássica, e filho, por sua vez, do grande tesouro paradigmático de nomes ilustres entre os quais alinha, com discreto mas inequívoco destaque, o padre-pai (Idem. grifo meu)

Ser ao mesmo tempo pai e filho - pai de uma obra clássica, e filho de um nome que se alinha entre os grandes: tal é a ambição do nosso compositor.

Para retomar os fios que armamos acima, é esse, precisamente, o ponto em que Pestana almeja encontrar uma individualidade, uma subjetividade. Colocar-se ao lado dos gigantes da música ocidental via filiação paterna, portanto, não significa, aqui, apenas desejo de tornar-se mundialmente reconhecido - como Beethoven, Mozart ou Haydn. Ou seja, não se trata de simples "sede de nomeada" em nível cosmopolita, mas de algo bem mais ambicioso: entrar em contato, via criação artística, com "valores superiores".

Segundo vimos acima, contudo, a individualidade de Pestana é uma “individualidade em crise" (Wisnik, 2004, p. 19).

Isso porque a paternidade à qual sofregamente o compositor de polcas almeja se filiar, conferindo-lhe dimensões tão megalomaníacas quanto transcendentais, é, em si mesma, esquiva - e esse é o ponto de inflexão da leitura 
de Wisnik ${ }^{58}$-, uma vez que afetada por um elemento salutar: a miscigenação que, segundo o ensaísta, concerne à figura do "padre pai" brasileiro:

A figura do padre pai é conhecida na história colonial brasileira. Gilberto Freyre, no seu melhor estilo, é enfático a respeito. Sintomaticamente, o padre pai se associa, em primeira instância, à miscigenação, dado que 'o intercurso sexual de brancos [...] inclusive eclesiásticos [...] com escravas negras e mulatas foi formidável' (...)” (Wisnik, 2004, p. 62).

Assim, à incógnita que gira em torno da figura do Pai em "Um homem célebre", se soma esse elemento que, se por um lado não se evidencia pelo escorregadio e esquivo das "bocas vadias" 59 , por outro lado se insinua no próprio processo de Pestana: ali onde ele mira as estrelas, sua música lhe devolve os salões; ali onde ele mira o silêncio, sua música lhe devolve o rumor; ali onde ele mira uma individualidade, sua música lhe devolve polcas-maxixe cujos títulos "Não bula comigo, nhonhô" -, por si só, apontam para a rasura étnico-cultural.

Em suma: ali onde ele busca a pureza do valor-gênio, sua música lhe devolve, via influxo inconsciente entranhado nas vísceras do valor-corpo, valorGenius ${ }^{60}$ : motivo pelo qual ele se torna uma "individualidade em crise" ao mesmo tempo em que um "índice da cultura" que aponta para esferas coletivas e imemoriais:

A questão, aqui, é que a polca amaxixada vaza os espaços fechados e os contextos de classe implicados no pianismo dos salões: ela se liga com o machete das ruas, com as flautas, clarinetes, oficleides, violões e cavaquinhos, com pandeiros e candongas - ela se irradia incontrolável, sai e volta pelo ladrão do inconsciente (...) (Wisnik, 2004, p. 78).

Por esse motivo, talvez, a observação dos "rumores" e "aparências" da vida exterior sejam tão doloridos ao nosso Pestana: ao mesmo tempo em que, em cada lance, afrontam seus desejos conscientes, são também provas vivas,

\footnotetext{
${ }^{58}$ Cujas nuances e consequências, que vão longe, não terei condições de dar conta nesse espaço.

${ }^{59}$ Como mostra José Miguel, o jogo entre o dito e o não-dito do narrador, nesse particular, aponta para problemas que dizem respeito à própria condição mulata do escritor Machado de Assis assim como ao modo como este, entre o decoro e a ousadia sub-repticiana, lida com o assunto.

${ }^{60}$ Reintroduzo, aqui, Giorgio Agamben (2007), adaptando suas questões às de José Miguel Wisnik.
} 
materializadas em salões, casas modestas e ruas da cidade, da força incontrolável - e incontornável - do corpo; e, no seu caso, das consequências resultantes da ação desse corpo.

Se um estilo é um devir ${ }^{61}$, e o devir aponta para encontros que ultrapassam o individual, nosso compositor, então, não tem estilo - muito embora sua música produza, incessantemente, estilo:

Já perto de casa viu vir dois homens: um deles, passando rentezinho com o Pestana, começou a assobiar a mesma polca, rijamente, com brio, e o outro pegou a tempo na música, e aí foram os dois abaixo, ruidosos e alegres, enquanto o autor da peça, desesperado, corria a meter-se em casa (Assis, 2008, p. 465).

\footnotetext{
${ }^{61}$ Como, em mais de uma ocasião, propõe Deleuze (cf. final do capítulo 3).
} 


\section{6 Dono da cidade, dono do mundo ou: Amor aos ossos}

Um homem dirige por São Paulo quando, distraindo-se, quase sobe no canteiro e atropela um morador de rua em sua precária habitação. Constrangido com o incidente, salta do carro em meio ao caos da cidade para se desculpar com aquele que, por pouco, não mata, e, aproximando-se, faz-lhe propostas tão inusitadas quanto excêntricas:

E aí? Olhe só (ele não olhou): eu posso oferecer a minha morada. Por uns dias. Façamos de conta que o senhor é o meu pai desaparecido. Há anos que o procuramos (...). Dar-lhe-ia, creia: melhor aparência e cuidados (Aguiar, 2008, p. 258).

As propostas não mobilizam o velho, que se limita a recuar. Este não fala a língua articulada dos homens: suas frases são "aéreas", seus períodos "obscuros", suas ideias "sem cabeça". Elas dizem: "o canário é senhor da gaiola que habita e da loja que o cerca. Fora daí, tudo é ilusão e mentira". Após o que, opondo resistência à tagarelice do motorista, se retira para dentro de sua habitação, - qual Bartleby para dentro de seu biombo verde ${ }^{62}$, - onde passa o tempo a ler livros de filosofia.

Enquanto isso, a cidade ao redor pulsa indiferente:

Os carros a caminho da morte não entendem nada. Ao redor, era tudo um inferno de calotas e capacetes. Saias, botões e binóculos. Cães e caminhões. Ambulantes e sapatos. E policiais armados (Aguiar, 2008, p. 258).

\footnotetext{
${ }^{62}$ Cf. MELLVILLE (2007).
} 
Publicado em Recontando Machado ${ }^{63}$, esse é o motivo inicial que anima o enredo de "De dentro do ovo para dentro da gaiola", recriação literária de "Ideias de Canário", por Marcelino Freire, em homenagem a Machado de Assis.

Inicio minha reflexão citando duas frases-conceito de Roberto Corrêa dos Santos (2011) sobre o termo "homenagem":

- "Homenagem: atitude estética e política deliberada de estabelecimento de modos específicos de relações amorosas com as obras alheias".

- "Homenagem: valer-se de estratégias discursivas diversas fortificando o impulso de criar diante do outro escolhido (atos de deferência e admiração como nutrientes éticos)" (Santos, 2011, p.40).

Assim, diga-se que: ações estético-afetivas (e políticas) para com a obra do outro $\rightarrow$ nutrientes éticos.

Sem o objetivo de desenvolver o tema no espaço da presente dissertação, vejamos o que significa, para Deleuze (2002), a noção de "ética" - que a toma das teses práticas de Espinosa, as quais representariam, por sua vez, as três grandes semelhanças entre o pensamento deste e Nietzsche.

Abramos um parêntese e, de modo muito simplificado, esbocemos as três teses:

- Quanto à consciência, a primeira "tese prática" propõe que se tome o corpo como modelo. Recusando a eminência da alma sobre o corpo - mas tampouco afirmando a eminência deste sobre aquela -, importa mostrar que ambos escapam às reduções propostas pela consciência. Longe de se constituírem como instâncias autônomas e estáveis, corpo e espírito seriam antes "conjuntos de partes vivas que se compõem e decompõem segundo leis complexas" (Deleuze, 2002, p. 25), ou seja, segundo relações de força das quais a consciência só é capaz de recolher os efeitos, mas não de entender/apreender as causas. Daí que se sente alegria ou tristeza quando um corpo (e/ou uma ideia) encontra outro corpo (e/ou outra ideia). Alegria e tristeza, contudo, seriam apenas os efeitos resultantes

\footnotetext{
${ }^{63}$ Fruto de proposta editorial da Record, o livro repete a iniciativa tomada por Osman Lins (1977) em Missa do Galo, variações sobre o mesmo tema: propor a um grupo de autores que recriassem, a sua maneira, contos de Machado de Assis. Como minha intenção não é, a rigor, discutir as questões que estão implicadas nesse tipo de proposta editorial, limito-me a dois textos - uma vez que estes dialogam com tópicos por nós tratados até aqui.
} 
dessas relações; suas causas (isto é, o princípio que rege essas forças e as compõe de modo complexo), a rigor, seriam inapreensíveis.

- Aos valores transcendentes Bem/Mal, a Ética opõe a "diferença qualitativa dos modos de existência" (bom/mau) do homem, na medida em que esses modos se dão mediante encontros:

(...) será dito bom (ou livre, ou razoável, ou forte) aquele que se esforça, tanto quanto pode, por organizar os encontros, por se unir ao que convém à sua natureza, por compor a sua relação com relações combináveis e, por esse meio, aumentar sua potência (...) Dir-se-á mau, ou escravo, ou fraco, ou insensato, aquele que vive ao acaso dos encontros, que se contenta em sofrer as consequências, pronto a gemer e a acusar toda vez que o efeito sofrido se mostra contrário e lhe revela a sua própria impotência (Deleuze, 2002, p. 29).

Limitando-se a recolher os efeitos desses encontros, a consciência, como vimos, desconhece-lhe as causas. Deleuze pontua: “Ora, basta não compreender para moralizar" (Idem). Nesse sentido, o conhecimento seria modal ali onde a moral é sempre dogmática: esta "não nos traz conhecimento algum, não dá nada a conhecer", enquanto que aquele está ligado à disposição que cada um tem para perceber e compor (boas) relações.

- Vinculadas às ilusões da consciência, as paixões tristes dizem respeito ao ressentimento, a tudo o que separa o homem da vida. Assim é que a crítica das paixões tristes, segundo Deleuze, está enraizada na teoria das afecções, quer dizer, no poder que o homem tem de ser afetado: "Espinosa não é daqueles que pensam que uma paixão triste tem algo de bom. Antes de Nietzsche, ele denuncia todas as falsificações da vida (...)" (Deleuze, 2002, p. 32).

Em suma:

Eis, pois, o que é a Ética, isto é, uma tipologia dos modos de existência imanentes, substitui a Moral, a qual relaciona sempre a existência a valores transcendentes. A moral é o julgamento de Deus, o sistema de Julgamento. Mas a Ética desarticula o sistema de julgamento (Deleuze, 2002, p.29. grifo meu).

Fechemos o parêntese e, tendo em mente essa última frase de Deleuze “(...) a Ética desarticula o sistema de julgamento” -, coloquemos as seguintes questões: 
- Em que medida as narrativas de Machado de Assis, ao encaminharem-se para a suspensão do juízo / tensão paradoxal, abrem espaço para que se pense em éticas de vida alternativas?

- Ao "recontarem" Machado, teriam os autores aproveitado aspectos anunciados em seus contos de modo a, trazendo-os para outro contexto cultural, usá-los como "nutrientes éticos" - como propõe Roberto Corrêa dos Santos?

Para discutir essas questões, lanço mão de dois contos: "De dentro do ovo para dentro da gaiola", de Marcelino Freire, e "Carta de uma mulher apaixonada" ${ }^{64}$, de Tatiana Salem Levy.

Com o intuito de propor correspondências entre aspectos da escrita desses autores e aspectos da escrita machadiana, recorto, também, alguns pontos levantados por Karl Erik Schфllhammer (2009) em dois capítulos de Ficção brasileira contemporânea.

\begin{abstract}
$* * *$
Em "O realismo de novo", Schфllhammer chama a atenção para o fato de que a crítica tem usado a expressão "novo realismo" para designar o trabalho de alguns escritores surgidos na virada do século XX para o XXI, como Marçal Aquino, Fernando Bonassi e Marcelino Freire.

"Mas o que justifica ver realismo na nova geração de escritores", pergunta o autor, - se não há, aí, "nenhuma volta às técnicas da verossimilhança descritiva e da objetividade narrativa"? (Schøllhammer, 2009, p. 53).

Para Schфllhammer, o que se vê é: "a vontade ou o projeto explícito de retratar a realidade atual da sociedade brasileira, frequentemente pelos pontos de vista marginais ou periféricos", afastando-se, contudo, tanto de um "realismo tradicional e ingênuo em busca da ilusão de realidade" quanto de um "realismo propriamente representativo" (Schøllhammer, 2009, p. 53-54).

Não se configurando nem como mimético nem como "propriamente representativo" (Idem), assim, o "realismo" a que se refere o autor de Ficção brasileira contemporânea - e esse é o ponto que nos interessa - seria, antes, um realismo de efeitos:
\end{abstract}

\footnotetext{
${ }^{64}$ Recriação literária de "Um esqueleto", conto publicado por Machado de Assis em 1875 no Jornal das Famílias sob o pseudônimo de Victor de Paula.
} 
Estamos falando de um tipo de realismo que conjuga as ambições de ser 'referencial', sem necessariamente ser representativo, e ser, simultaneamente, 'engajado', sem necessariamente subscrever nenhum programa político ou pretender transmitir de forma coercitiva conteúdos ideológicos prévios (Schøllhammer, 2009, p. 54).

Da mesma maneira que não intento discutir o livro Recontando Machado no que diz respeito aos seus aspectos gerais (como referido em nota no início do presente capítulo), não é minha intenção discutir literatura contemporânea no tocante aos seus problemas teóricos, corpus de autores, heterogeneidade de propostas etc.

A despeito disso, a questão dos efeitos mencionada acima é pertinente tanto para os contos de Marcelino Freire e Tatiana Salem, por mim escolhidos, como para as narrativas de Machado que lhes servem de estímulo: "Ideias de Canário" e "Um esqueleto".

Para precisar teoricamente a noção de "efeito" (e suas implicações), portanto, precisarei tocar em tópicos, via Schфllhammer, que concernem à literatura contemporânea - uma vez que é discorrendo a seu respeito que o autor formula essa noção.

De saída, diga-se que falar em efeito implica falar na relação interativa que se dá entre autor-linguagem-leitor; interação essa que possuiria, por sua vez, "força ética de transformação" - na medida em que, ao investir no "aspecto performático e transformador da linguagem e da expressão artística", privilegia o "efeito afetivo e sensível em detrimento da questão representativa" (Schøllhammer, 2009, p. 56-57. grifo meu). Vejamos em que sentido isso se dá.

Em “Que significa literatura contemporânea?”, o autor propõe, no encalço de Giorgio Agamben e Roland Barthes, que "ser contemporâneo" é estar em desacordo, em defasagem, em relação de descontinuidade com o tempo presente criando-se, assim, um ângulo que permite ao artista expressar o presente, e não representá-lo de modo a levar a cabo projetos utópicos que apontariam tanto para um futuro redentor quanto para um passado coerente e articulado (como se dá no projeto moderno). Assim, 
(o) escritor contemporâneo parece estar motivado por uma grande urgência em se relacionar com a realidade histórica, estando consciente, entretanto, da impossibilidade de captá-la na sua especificidade atual, em seu presente (Schøllhammer, 2009, p. 10. grifo meu).

Diante desse quadro (a que faço alusão apenas com o intuito de chegar ao ponto que nos interessa), o autor identifica um traço que, segundo sua perspectiva, é marcante no trabalho dos escritores com que trabalha - dentre os quais Marcelino Freire. Trata-se da urgência que, para além do mero imediatismo, da mera instantaneidade, se apresenta também como eminência:

Dois argumentos se juntam aqui: uma escrita que tem urgência, que realmente "urge", que significa, segundo o Aurélio, que se faz sem demora, mas também que é eminente, que insiste, obriga e impele, ou seja, uma escrita que se impõe de alguma forma (Schøllhammer, 2009, p. 11).

A par do desejo de dar conta da realidade mais imediata (estando-se ciente, contudo, da impossibilidade de, a rigor, representá-la / recriá-la), erige-se assim uma escrita que se quer urgente e eminente. Isto é, que se faz "sem demora" ao mesmo tempo em que se impõe enquanto concretude formal.

Essa "urgência" aponta precisamente para a possibilidade de a expressão artística funcionar não como veículo ideal para programas político-ideológicos pré-estabelecidos, mas como instância material através da qual a "experiência afetiva" (Schøllhammer, 2009, p. 12) se apresenta em sua potência transformadora.

Como consequências expressivas / formais desse estado de coisas, o autor de Ficção brasileira contemporânea identifica certas tendências na recente literatura brasileira; tendências essas que concorrem tanto para os efeitos que se logram obter, quanto para a eficiência artística (e/ou popularidade mercadológica) das obras junto ao público leitor de uma sociedade predominantemente midiática.

Certamente poderemos apontar a popularidade das formas ultracurtas de minicontos e das estruturas complexas e fragmentadas como um sintoma, mas também o hibridismo crescente entre a escrita literária e a não literária, seja jornalística e pública, seja pessoal e íntima (Schøllhammer, 2009, p. 14). 
Esse último ponto [o da "eficiência artística" dos textos junto ao público leitor] nos parece particularmente relevante, uma vez que muitos dos contos de Machado de Assis (para não dizer a maioria deles), antes de reunidos em volumes, foram publicados também em jornais e revistas. Isto é, em veículos / suportes materiais que levavam em consideração tanto o perfil do público leitor (e seu horizonte de expectativas) como a natureza transitória / perecível das informações aí veiculadas.

Escusado dizer que essa relação autor-linguagem-leitor funcionava, já para Machado, como motor para sua escrita, proporcionando resultados que, a meu ver, apontam para aquela "força ética de transformação" 65 (Schøllhammer, 2009, p. 56) a que se refere Sch $\phi$ llhammer.

Digo isso pelo seguinte motivo: na relação interativa entre autor-linguagemleitor suposta - e muitas vezes explicitada - na escrita de Machado de Assis, os efeitos sensíveis são particularmente importantes; e se dão, como mostra Renato Cordeiro Gomes (2008) ${ }^{66}$, no jogo permanente entre enunciado e enunciação, dito e não dito, horizonte de expectativa do leitor e desvio com potência suspensiva / desconstrutora.

Nesse sentido, pode-se dizer que a escrita machadiana configura-se também como uma escrita de efeitos.

\section{$* * *$ \\ Um esqueleto}

Publicado no Jornal das Famílias, "Um esqueleto" tem tudo para ser uma "história de horror". E é possível que o público leitor ao qual se destinava o jornal em questão, - um público predominantemente feminino, segundo informa Gomes (2008) -, não o lesse de outra maneira.

Eis o resumo do enredo:

\footnotetext{
${ }^{65}$ Em "Ideias de Canário", sugerimos que o jogo de forças com a verossimilhança funciona ao mesmo tempo como agente confortador para o leitor (ao ser mencionada a possível "loucura de Macedo") e como espaço a partir do qual o absurdo torna-se possível como força desconstrutora. cf. cap. 4.

${ }^{66}$ Cf. "Singulares ocorrências: claro enigma de uma ficção". O ensaísta, contudo, não usa esse vocabulário.
} 
Um grupo de rapazes conversa sobre artes, letras e política ${ }^{67}$. Entre uma anedota e outra, intercaladas à seriedade do assunto, Alberto, um dos convivas, refere a história de um certo Belém: um homem que teria os seus sessenta anos, fora seu professor de alemão e cuja excentricidade excedia, em muito, a média (escrevera um romance, um livro de teologia e dizia ter descoberto um planeta...).

Viúvo do primeiro casamento - cuja mulher chamava-se Luísa -, Belém casa-se, em segundas núpcias, com Marcelina, moça muito mais jovem do que ele, também viúva, e que, num primeiro momento, encanta-se com seu jeito singular.

As coisas mudam sensivelmente, contudo, quando a seguinte situação - em si mesma absurda / inverossímil - é revelada: em casa, o homem conserva guardado o esqueleto da primeira mulher, que ele mesmo havia assassinado diante da suspeita de adultério.

Diante dos remorsos por ter matado a primeira mulher em vão (uma carta anônima prova que Luísa era inocente), Belém passa a cultivar um estranho hábito: todo dia, na hora das refeições, acomoda o esqueleto à mesa para que ceassem os três juntos: ele, Marcelina e Luísa.

Por Luísa, o excêntrico homem nutre então um amor peculiar e obsessivo, ao mesmo tempo em que ameaça Marcelina com a presença do esqueleto: “(...) é para que minha segunda mulher esteja sempre ao pé da minha vítima, a fim de que se não esqueça nunca dos seus deveres (...)" (assis, 2008, p. 1368).

Não é preciso dizer que, aos olhos tanto de Marcelina quanto de Alberto, o “amor" de Belém pelo esqueleto seria doentio, imoral, insano.

Independente de como se julgue moralmente Belém, é precisamente nesse ponto, contudo, que "Um esqueleto" dramatiza sua radicalidade, trazendo à tona tanto o problema do "ponto de vista de apreciação" a partir do qual se criam / pensam os valores morais - para relembrarmos o Deleuze de Nietzsche e a filosofia $^{68}$-, como o elemento paradoxal que deixa em estado de suspensão a validade do valor vigente: no caso do conto em questão, a existência da alma

\footnotetext{
${ }^{67}$ Note-se que a situação ficcional é praticamente idêntica à do conto "O espelho", de Papeis Avulsos: um grupo de rapazes discute questões de "alta transcendência" quando um deles, Jacobina, expõe a teoria da primeira e da segunda naturezas do homem - na qual é problematizada a independência da "alma interior" (substância) em relação à "alma exterior" (vida social, mundo das aparências etc.) (ASSIS, 2008: 322-328).

${ }^{68}$ Cf. capítulo 4.
} 
como instância que independe do dado corporal - e, em última análise, a existência de um fundo que independe de um exterior / superfície.

O elemento paradoxal responsável pela suspensão do julgamento corresponderia, no conto de Machado, a uma operação narrativa onde se pode perceber uma aproximação entre o raciocínio dos céticos e o de Espinosa, isto é: situar alma e corpo no mesmo nível de importância e, por conseqüência, esvaziar o lugar transcendente do espírito, o qual responderia pelos dogmas morais.

No conto, isso que chamei de operação narrativa se faz através do humor negro, que desconsidera o apelo moral, dogma apoiado nos valores transcendentes $\mathrm{Bem} / \mathrm{Mal}$, em favor dos modos de existência $\mathrm{bom} / \mathrm{mau}$ - os quais se dão, conforme mostra Deleuze (a propósito das teses práticas de Espinosa), a partir da capacidade / disposição que cada um tem para perceber e compor (boas) relações.

Ao trabalhar com o humor negro, assim, trabalha-se com as noções modais de $\mathrm{bom} / \mathrm{mau}$, e não com as noções transcendentais de Bem/Mal - uma vez que aquelas é que são as responsáveis pela criação dos "nutrientes éticos" a que se refere Roberto Corrêa dos Santos.

Interessante notar que o elemento paradoxal mencionado acima (semelhante, em certa medida, ao problema das "duas almas" de "O Espelho") se dá no espaço de um diálogo entre Belém e Alberto - o que me faz pensar na densidade / concretude da escrita de Machado que, já em 1875, faz vacilar, pela visada do detalhe, todo um complexo valorativo.

Nesse sentido, "Um esqueleto" já traz um cadinho da estrutura fragmentada ${ }^{69}$ que tornará célebre a ficção machadiana pós-Memórias Póstumas de Brás Cubas.

Cito trechos do diálogo ao qual me refiro:

- Doutor, disse eu, respeito os seus hábitos; mas não me dará a explicação deste?

- Este qual? disse ele.

Com o gesto indiquei-lhe o esqueleto.

- Ah!... respondeu o doutor; um hábito natural; janto com minhas duas mulheres.

- Confesse ao menos que é um uso original.

\footnotetext{
${ }^{69}$ Em relação ao fragmento, Lacoue-Labarthe e Jean-Luc Nancy propõem: "É também o que, aliás, obrigaria a analisar - mas nós o assinalamos aqui simplesmente de passagem - o modo como o 'gênero' fragmentário não é talvez, de fato, limitado à forma fragmento dos Românticos. Pode-se ler em Athenäum 77 a maneira como diálogo, cartas e 'memórias' (...) remetem ao fragmentário" (LACOUE-LABARTHE, Philipe \& NANCY, Jean-Luc, 2004: 75. grifo meu).
} 
- Queria que eu copiasse os outros?

- Não, mas a piedade com os mortos (...)

$\mathrm{O}$ doutor deu uma de suas singulares gargalhadas, e estendendo-me o prato de sopa, replicou:

- O senhor fala de uma piedade de convenção; eu sou pio à minha maneira. Não é respeitar uma criatura que amamos em vida, o trazê-la assim conosco, depois de morta?

\section{$(\ldots)$}

- Confesse, confesse que está com medo.

Fiz-lhe um sinal negativo com a cabeça.

- É medo, é, como esta senhora [Marcelina] que está ali transida de susto, porque ambos são dous maricas. Que há entretanto neste esqueleto, que possa meter medo? Não lhes digo que seja bonito; não é bonito segundo a vida, mas é formosíssimo segundo a morte. Lembrem-se que isto somos nós também; nós temos de mais um pouco de carne.

- Só? Perguntei eu intencionalmente.

O doutor sorriu-se e respondeu:

- Só.

Parece que fiz um gesto de aborrecimento, porque ele continuou logo:

- Não tome ao pé da letra o que lhe disse. Eu também creio na alma; não creio só, demonstro-a, o que não é para todos (...) (Assis, 2008, p.1366. grifo meu).

Abramos um parêntese. No que toca ao fragmento, diga-se que este configurar-se-ia como quebra da continuidade do raciocínio lógico, que é o raciocínio moral. Ou seja, ele corresponde à conjunção paradoxal da energia que é momentânea do incompleto / precário, com o desejo impossível de completude (que equivale à estabilidade / permanência). Isso leva à maneira como o pensamento se processa na escrita artística, uma vez que é nesta última que se encontra (e se potencializa) a possibilidade de transformação ética. Feche-se parêntese.

Pois, para Belém, respeitar os mortos não é enterrá-los, mas trazê-los consigo, em vida - ideia regida por uma concepção em tudo distinta da "piedade de convenção" de Alberto. E frente à pergunta desconcertada deste último em relação à existência da alma - "Só?" -, Belém responde decididamente - "Só" para, linhas adiante, se desdizer: "Não tome ao pé da letra (...)" (Idem).

Após o embate entre afirmações e negações, que instaura, em certa medida, uma espécie de tensão momentânea, interessante é observar como esse embate (aparentemente) se resolve: Belém afirma que não apenas crê na alma, como também "demonstra-a". E, logo em seguida, pacifica de todo o debate: "Mas a 
alma foi-se embora; não podemos retê-la; guardemos isto ao menos que é uma parte da pessoa amada" (Idem).

De nossa parte, perguntamos: e como Belém demonstra a existência da alma ao longo de todo o conto? A resposta: continuando a fazer exatamente o que vinha fazendo até ali: desfilando com o esqueleto, acomodando-o à mesa, e considerando-o "formosíssimo segundo a morte".

Isto é, a mesma solução de enredo funciona a um só tempo como dado visível e invisível: a afirmação final de que "a alma foi-se embora (...)" é o elemento visível / pacificador para as leitoras virtuais do Jornal das Famílias, ao passo que o tópico da "demonstração" da existência da alma é o elemento invisível / perturbador do sistema de pensamento estabelecido ${ }^{70}$.

A essa altura, infere-se que vida e morte, talvez, não tenham os mesmos sentidos para as duas personagens: ali onde um encontra-se constrangido pela "piedade de convenção", o outro faz dos ossos dobra da alma - tal qual a farda de Jacobina que, removida frente ao espelho, faz com que a "alma interior" perca seus contornos a ponto de desaparecer. Em ambos os casos, trata-se, a meu ver, da mesma poética das superfícies, da mesma poética anti-essencialista que a ficção de Machado parece dramatizar.

Independente - repito - de como se julgue Belém em termos morais (uma vez que assassinar a primeira esposa e ameaçar a segunda, para todos os efeitos, não me parecem atitudes das mais louváveis), o fato é que a tensão entre opostos referida no diálogo acima, por si só, abre espaço para que se pense outra ética de vida que não o "julgamento de Deus, o sistema de julgamento" (Deleuze, 2002, p. 29) a que se refere Deleuze.

Como quer que seja, o contista não dá ao excêntrico homem nenhuma punição de ordem moral no que diz respeito ao desfecho da história. Isso porque "Um esqueleto" possui dois finais: a história de Belém propriamente dita, e a história contada por Alberto aos convivas que discutiam artes, letras e política antes de ouvi-la.

Assim é que: por um lado, desconfiado de ter sido traído novamente (dessa vez por Marcelina e seu aluno de alemão), Belém não pune ninguém (e tampouco

\footnotetext{
${ }^{70}$ Essa espécie de corpo a corpo com o leitor, por assim dizer, seria um exemplo, a meu ver, daquela interação autor-linguagem-leitor de que falávamos acima via Schфllhammer: o pensamento entra em ação menos através de conceitos e mais através de efeitos criados pela própria lógica interna da narrativa - no caso, um diálogo entre duas personagens.
} 
é punido com algum destino fatal): ele limita-se a pegar o esqueleto de Luísa e desaparecer no mato.

Por outro lado - e aqui vai uma boa dose de concessão às leitoras do Jornal das Famílias -, "Um esqueleto" se encerra com Alberto dizendo aos convivas que Belém, na verdade, nunca existira: "Mas o Belém não existiu nunca, eu quis apenas fazer apetite para tomar chá. Mandem vir o chá” (Assis, 2008, p. 1371).

Como mostra Renato Cordeiro Gomes (2008) em "Singulares ocorrências: claro enigma de uma ficção", contar histórias dentro de histórias é um dos artifícios machadianos para que seja possível fazer concessões ao leitor e, ao mesmo tempo, deixar em suspenso juízos de ordem moral - operação que se dá no jogo dinâmico entre enunciado e enunciação, autor e leitor, "ponto de contato" e "ponto de desvio" (Gomes, 2008, p. 132), e, por que não, linguagem e efeito sensível.

Após revelar aos convivas a natureza fictícia / inventada de Belém, diz-nos o narrador de "Um esqueleto": "É inútil dizer o efeito desta declaração". Creio que as leitoras do Jornal das Famílias diriam o mesmo.

\section{Carta de uma mulher apaixonadal De dentro do ovo para dentro da gaiola}

Em "Carta de uma mulher apaixonada", Tatiana Salem Levy radicaliza aquilo que em "Um esqueleto" é mais uma sugestão que, de fato, uma realização: a possibilidade de, a partir da experiência sensorial-afetiva, se chegar a outros modos de vida.

Trazendo o universo de "Um esqueleto" para a esfera "pessoal e íntima" (Schøllhammer, 2009, p.14), para usarmos a expressão de Schфllhammer, "Carta de uma mulher apaixonada" é uma narrativa epistolar de Marcelina a Belém - na qual, após rememorar, sem rancores, a história do casal, a moça elucida o motivo de sua missiva: apaixonando-se pelo esqueleto de Luísa, - que a certa altura lhe provoca uma mudança irreversível de olhar (desencadeada pelo que nos ossos há 
de silêncio, de ausência e de elemento sensível), - Marcelina resolve fugir com este último, deixando o marido:

Sua estrutura óssea e sua falta de gestos e palavras me garantiram uma eternidade que seu excesso de discursos e gesticulações, Belém, não garantia. Ao contrário: quando estava com você, lembrava-me a cada instante da nossa precariedade, da finitude que nos molda (Aguiar, 2008, p. 388).

Como se vê, é a "estrutura óssea", - sua solidez, seu aspecto mineral -, que faz com que a vida se apresente enquanto potência afirmativa, e não os "gestos e palavras", "discursos e gesticulações" de Belém que, no caso do conto em questão, intensificam a precariedade existencial.

Nesse sentido, creio que por trás da escrita fluida e não experimental de Tatiana Salem - e espalhado, aqui e ali, em meio ao fluxo narrativo de Marcelina -, esteja em jogo todo um investimento que resiste (e não necessariamente se opõe, binariamente) tanto à linguagem articulada quanto à perenidade dos valores eternos.

Neste particular, o período que encerra a narrativa é paradigmático, quando a ideia de "eternidade" é assegurada não pela união das almas, ou seja, das substâncias e instâncias superiores (valor-gênio), mas pela união dos ossos, dos sentidos, do mineral, do corpóreo - sugerindo, assim, tanto um outro sentido para a ideia de "eternidade" como um outro sentido para a própria ideia de "vida". Como se, investindo naquilo que chamei acima de "poética das superfícies" anunciada em "O esqueleto" / "O espelho" (e, talvez, em boa parte da ficção de Machado de Assis), a contista retirasse para si os "nutrientes éticos" (Santos, 2011, p. 40) a que se refere Roberto Corrêa dos Santos:

Não tenha raiva, não amaldiçoe a sua sorte. Tampouco venha atrás de mim, pois jamais me encontraria. Estou levando Luísa para um lugar onde ninguém nos descobrirá. Quando estiver terminado de ler essas últimas palavras, certamente já estarei a muitos quilômetros de distância, perdida com Luísa no meio da floresta, vivendo sem pressa nem receio o nosso amor, até o dia em que terei o mesmo destino dela, e nossos ossos se unirão para sempre, confirmando assim a certeza da eternidade (Aguiar, 2008, p.391). 
Em suma: assim como Belém demonstra a existência da alma a partir do corpo, Marcelina, apropriando-se de sua "teoria" e, em certa medida, voltando-a contra o marido, confirma a certeza da eternidade a partir da união dos ossos...

No mais, são frases espalhadas ao longo do conto. Frases que, imersas no universo privado-afetivo de Marcelina, provocam abalos ético-epistemológicos sem, contudo, alardeá-los em grandes programas. Trata-se, para retomarmos Schфllhammer, da possibilidade de transformação que, embora correndo todo o risco de não se consumar efetivamente, ali fica como uma promessa - possível lançada ao acaso da leitura e seus efeitos:

Fomos até o escritório e lá estava ele [o esqueleto], ereto, feito não temesse nada. Desafiava-nos com suas cavidades oculares, ameaçando-nos com a falta de olhar, impondo sua presença como se a morte o tornasse mais vivo do que nós (...).

E se no inicio sentia raiva e temor, com o passar do tempo, comecei a nutrir por ele - ela - um sentimento inusitado (...). Tocava em seus ossos, mexia nas mãos, nos braços, passeava com ela pela casa (...).

O que me trouxe, com o esqueleto, foi um presente especial, que me fez enxergar e sentir coisas que eu nunca imaginara antes (Aguiar, 2008, p. 383-387).

Assim como "Carta de uma mulher apaixonada", "De dentro do ovo para dentro da gaiola" também trabalha com radicalizações. Em ambos os casos, contudo, não se trata, a rigor, de radicalizações de ordem crítico-teórica - uma vez que as narrativas machadianas, em si mesmas, já são um tanto radicais em sua realização. Trata-se, isso sim, de radicalizações temático-formais que levam em consideração os aspectos materiais das narrativas e seus efeitos sensíveis.

Assim, se o fluxo narrativo-epistolar de "Carta de uma mulher apaixonada" potencializa as insinuações de "Um esqueleto" (ao mesmo tempo em que delas se nutre), a estrutura "complexa e fragmentada" (Schøllhammer, 2009, p. 14) de "De dentro do ovo para dentro da gaiola" incorpora, em cada palavra, em cada frase, aquilo que em "Ideias de Canário" é investido de potência desconstrutora: o devirsonoro que tanto anima a narrativa como entra em choque com intenções pacificadoras.

Como vimos no capítulo 4, ali onde Macedo procurava a definição do mundo via linguagem verbal (valor-trabalho), a "música" do canário devolvia-lhe, 
em cada lance, um mundo perspectivado pelo trilo insistente. Amplificando esse dado sonoro, Marcelino Freire o faz funcionar em sua narrativa.

Se é verdade que a escrita de Freire, por si só, já é uma escrita com inclinação para o poético e o sonoro, como propõe Schфllhammer - “(...) mas há sempre algo mais visceral e menos irônico em Freire, um desejo irresistível e, principalmente, uma vontade musical de criar contos como cantos" (Schøllhammer, 2009, p.68) -, trata-se aqui, então, de um feliz encontro.

De modo que em "De dentro do ovo para dentro da gaiola", tudo é pássaro: o destino fecha as "asas". A metrópole é um "ninho". O morador de rua "gorjeia" e, com olhos de "coruja bêbada", "bica-se" para dentro de seu "viveiro". No céu, o "vôo" do avião. Na avenida, a motocicleta que passa "voando". O motorista distraído quase "pousa" as rodas do veículo no canteiro... Enfim, é como se o escritor aproveitasse a frase proferida por Macedo a certa altura de "Ideias de Canário" - "todo eu era canário" ${ }^{11}$ - e a potencializasse ao infinito.

O devir-música e o devir-pássaro que atravessam seu conto, entretanto, possuem aqui, a meu ver, uma função mais específica: atravessando os elementos materiais da escrita e atingindo o narrador do conto (o motorista) via contato estabelecido entre este último e o morador de rua, eles articulam, a um só tempo, 1) tanto o alcance desconstrutor / perspectivístico de "Ideias de Canário" quanto 2) a inclinação, mencionada por Schфllhammer em Ficção brasileira contemporânea, de se dar conta de uma realidade social miserável e conturbada valendo-se de efeitos e não de técnicas mimético-representativas de narração.

Assim, o "gorjeio" e os olhos de "coruja bêbada" (entre outras imagens) do morador de rua de "De dentro do ovo para dentro da gaiola", ao mesmo tempo em que se apresentam como crítica aguda de uma situação física degradante, concorrem para tornar inoperantes tanto o modo de vida que rege a cidade grande, quanto a boa consciência, o paternalismo, e as vontades de pacificação que animam o motorista - misto de Macedo com Pestana, este último acredita que o senhor de longas barbas pode ser seu pai desaparecido e, levando-o para casa, deseja domesticar aquilo que se quer, no mais, indomesticável: como Bartleby de seu biombo verde, o velho mira o mundo de outra perspectiva, devolvendo ao narrador não mais que pios desestabilizadores).

\footnotetext{
${ }^{71}$ (ASSIS, 2008, p.569).
} 
Interessante notar que o aspecto ao mesmo tempo denso e econômico da escrita de Marcelino Freire - como, enfim, a de Machado de Assis - é capaz de dar conta, através do investimento no detalhe, de dados que, aparentemente gratuitos, possuem relevância teórica.

Assim é que, ao quase atropelar o velho no canteiro e saltar do carro em meio ao trânsito frenético, todo o modo de organização da cidade grande entra em ação, deixando o motorista algo confuso em relação ao que, naquela situação, seria mais adequado / correto ser feito:

Disse-lhe bom-dia. Creio que não me ouviu porque a buzina atrapalhou. E a outra buzina e a outra. No calor da pressa. Agora mais essa: a minha consciência em crise e a cidade é quem paga. Você não poderia deixar esse remorso para outro dia? Quis me perguntar o guarda, já interditando a área. Isso porque meus pneus cantaram alto e ali perto havia um hospital e eu arrebentei a guia, etc. e tal. O meio fio por um fio (Aguiar, 2008, p.257).

Entre a sua "consciência em crise", o desleixo insensível do guarda, e o velho à sua frente, o narrador deixa-se prender por este último.

O conto, então, se desenrola - entre a sintaxe fragmentada de Marcelino Freire e frases de "Ideias de Canário" infinitamente proferidas pelo morador de rua: "o canário, dono do mundo, habita gaiola vasta, branca e circular, donde mira o resto. Tudo o mais é ilusão e mentira (...)".

Quando percebe, o motorista encontra-se alheio tanto a si mesmo quanto à lógica da grande São Paulo - coisa que só se evidencia ao final da narrativa, quando o velho lhe escapa de casa.

Entre o trilar insistente deste último e a tagarelice do narrador do conto, qualquer coisa de inexplicável se passa; qualquer coisa de inapreensível e, talvez, de inominável. De todo modo, me parece que funciona tanto como "nutriente ético" para a ficção de Freire, quanto como "força ética de transformação" para a realidade do motorista na grande São Paulo.

Foi quando soube, ao me levantar: o velho fugiu da gaiola. O quê? (...). Sem ele, eu teria de voltar ao escritório. Aos carimbos e papeis. Aos carros e semáforos. Ave Maria! Não pode ser. Eu o procuraria, sim, segundas seguidas. Pousaria os pneus em outros canteiros, ilhas e esquinas. Até o fim da minha vida. Esta pena! (Aguiar, 2008, p. 260). 
Para todos os efeitos, deixo citada mais uma frase-conceito de Roberto Corrêa dos Santos:

"Homenagem: difundir pulsões". 


\section{7 \\ Considerações finais}

Mais que recriações literárias de "Um esqueleto" e "Ideias de canário", "Carta de uma mulher apaixonada" e "De dentro do ovo para dentro da gaiola" são leituras de Machado de Assis; leituras que, fazendo-se através da escrita, entendida, aqui, como conceito operatório, qual Leyla Perrone Moisés lendo Roland Barthes, - mostram-se sensíveis aos operadores críticos da ficção machadiana.

Entre o que no trabalho estilístico há de pulsão corporal, inconsciente, e o que há de gesto repetido (obsessão que toma conhecimento de si no em se fazendo do processo criativo), o ato de "homenagear" apresenta-se como: sem abandonar o "ser o que se é" a que se refere Roberto Corrêa dos Santos, sabe aproveitar o trabalho artístico do outro (inscrito na matéria saturada de efeitos) de modo a dele retirar os nutrientes indispensáveis (porque éticos) a partir dos quais a transformação (não alardeada, porque não programática) se torna possível - um possivel.

Se um estilo "é sempre também um estilo de vida (...), a invenção de uma possibilidade de vida, de um modo de existência" (Deleuze, 1992, p. 130) - como propõe Deleuze -, a construção estilística, então, não se encontra nem aqui nem ali, nem no "eu" nem no "ele": desubstancializada, ou seja, livre do "sistema de julgamento" que aprisiona o indivíduo à Ideia, ela é antes um complexo material que, atravessando o corpo, a linguagem e o mundo (menos como referente e mais como espaço onde as forças se encontram instáveis, porque vivas), produz encontros mediante efeitos. Homenagear, nesse sentido, - na esteira da segunda tese prática de Espinosa, - é saber organizar (bons) encontros, tanto para si ("escrevemos para nos tornarmos impessoais, para nos tornarmos geniais" 72 , diria Agamben) quanto para a arte que se faz.

Tendo isso em vista, se no plano pessoal-empírico Tatiana Salem Levy e Marcelino Freire encontram, via processo escritural, Machado de Assis (com isso

${ }^{72}$ (AGAMBEN, 2007, p.18). 
se tornando geniais), "Carta de uma mulher apaixonada" e "De dentro do ovo para dentro da gaiola" encontram "Um esqueleto" e "Ideias de Canário", respectivamente. Ou seja: a arte que se faz se compraz em retirar para si aquilo que a arte do outro tem de forte.

Nesse sentido, um estilo (uma escrita), não se limita a desubstancializar o "eu" (embora, de modo algum, isso seja pouca coisa): para além disso, ele faz propostas. Quero dizer: se um estilo possui "força ética de transformação" (para falarmos com Schфllhamer), ele precisa incomodar.

Assim, sob os influxos do valor-corpo que anima / orienta todo valortrabalho (embora Macedos, Pestanas e Matias não se conformem com a falta de controle), Tatiana Salem e Marcelino Freire souberam aproveitar aquilo que na poética de Machado de Assis é forte, gesto repetido: a valorização do elemento inconsciente, corporal, sensitivo, sonoro, exterior. Trata-se, a meu ver, de uma poética que, apontando para a superfície, concorre para constranger a linguagem sobretudo a verbal - ali onde ela pode ser mais perigosa: no ato de conferir Valor.

Ao fazê-lo, essa poética, esse "estilo" (que, nesse caso, se apresenta como uma "teoria da escrita" perpetrada pelas vias da ficção) suspende julgamentos, juízos e valores universais. E toca, com isso, mediante perceptos e afectos, isto é, mediante efeitos (e não conceitos), tópicos que dizem respeito a correntes não dogmáticas de pensamento, uma vez que não essencialistas.

Dessas suspensões, abre-se espaço para possibilidades, as quais, a meu ver, foram bem aproveitadas tanto em "Carta de uma mulher apaixonada" como em "De dentro do ovo para dentro da gaiola" - na medida em que essas escritashomenagem criam modos, éticas de vida possíveis.

Eis, assim, as três frentes básicas com as quais a presente dissertação procurou lidar: a discussão sobre o conceito de estilo, a observação de aspectos e operadores críticos da escrita de Machado de Assis, e, por fim, a leitura dos contos dos dois autores contemporâneos que se lançaram à tarefa de reescrever Machado.

O recurso a essas três frentes de atuação, contudo, constitui-se mais como um movimento que se quer dinâmico, - em sua proposta de articular conceitos e 
ideias afins, - do que como uma tentativa de dar conta, a rigor, dos problemas constitutivos de cada uma delas.

Dizendo de outro modo: o presente trabalho, ao tomar o conceito de "estilo" como uma de suas preocupações, não é, em sua totalidade, um trabalho sobre o conceito de estilo.

Da mesma maneira, ao discorrer sobre traços da escrita de Machado (valorizados e recortados por mim como pesquisador), de modo algum tive a pretensão de afirmar que esses traços dizem respeito à totalidade da obra do autor fluminense ou funcionam como chaves de leitura inequívocas e excludentes.

Receio que o mesmo se pode afirmar sobre as coletâneas de contos que se apresentam ao público leitor como livros de "homenagens" a Machado de Assis: embora tenha entrado em contato com quatro livros, limitei-me somente às duas narrativas mencionadas acima - "Carta de uma mulher apaixonada" e "De dentro do ovo para dentro da gaiola". Isso me leva a dizer que minha intenção não foi discutir teórica e criticamente esse tipo de produção como um todo, mas sim retirar dos contos em questão traços que, a meu ver, dialogam de maneira mais profícua com os recortes que propus.

Em suma: sendo um trabalho que versa sobre estilo, a presente dissertação não se restringe, entretanto, a esse conceito; sendo um trabalho que propõe considerações sobre aspectos da escrita de Machado de Assis, a presente dissertação não os toma como tema central e determinante; e sendo um trabalho que lida com o assunto da recriação literária, este último ocupa, a rigor, apenas as considerações iniciais e o capítulo seis.

Daí a necessidade de se chamar atenção para o seguinte fato: as três frentes - conceito de estilo, escrita machadiana e contos-homenagens - devem ser pensadas, tanto quanto possível, em conjunto.

Daí a necessidade, também, de eu não ocultar os passos que dei ao longo do meu próprio percurso escritural. Percurso esse que, entre caminhos possíveis (e alguns descaminhos desconcertantes), me obrigou a fazer a seguinte escolha: escrever ensaisticamente. Nesse ponto, peço licença para colocar uma pergunta retórica: será que escrever ensaisticamente (ou tentativa de) foi, para mim, uma escolha?

Em meados do ano passado, quando enviei à minha orientadora o primeiro capítulo de Estilos: entre Machado e seus recriadores, minha intuição - mais que 
minha consciência - foi partir de Machado de Assis. Isso porque "O cônego ou metafísica do estilo" (um dos contos desse ficcionista-pensador), além de uma teoria sobre o estilo, apresenta-se, mais amplamente, como uma teoria sobre a escrita. Teoria essa que, por sua vez, leva a pensar a construção estilística como uma esfera complexa / produtora de pensamento, e não como instância meramente ornamental a sustentar a partição tradicional entre forma e conteúdo, pensamento e expressão etc.

Isto é: em se tratando de "O cônego ou metafísica do estilo", falar sobre "estilo" é já falar sobre "escrita" / "escritura" - para (re)convocarmos este que é um conceito importante para Roland Barthes, teórico de cujo arcabouço teórico tomei a liberdade de aproveitar duas noções que, em maior ou menor grau, perpassam os seis capítulos da presente dissertação: valor-trabalho e valor-gênio (ambas retiradas do ensaio "O artesanato do estilo"). A partir delas, cunhei uma terceira noção: valor-corpo.

Como visto no primeiro capítulo, nesse conto de Machado há todo um investimento no corpo como instância que, via elemento sensorial, põe em questão tanto a autonomia da consciência quanto a validade de uma esfera transcendental a animar o processo de escrita: quando redigia um sermão para pregar em uma festa, o personagem-escritor Matias, a certa altura, não consegue atinar com o adjetivo mais adequado que pudesse completar o sentido de um certo substantivo. No momento em que se dá a interrupção do processo escritural do padre, o narrador do conto propõe: "subamos à cabeça do cônego" e, a partir dessa estratégia ficcional, evidencia todo o trabalho inconsciente e arredio ao controle que se dá no cérebro da personagem.

Ou seja, o narrador torna evidente ao leitor o jogo de forças em relação que, operado pela dinâmica da língua / linguagem (objeto social por definição, segundo Barthes), faz com que a busca do cônego Matias pelo adjetivo perdido não se apresente nem como uma escolha consciente (valor-trabalho) nem como inspiração divina (valor-gênio).

Em outras palavras: o personagem-escritor não possui qualquer controle sobre sua escrita que, antes, se dá pela atração "sexual" (portanto corpórea) entre as palavras - cuja articulação deve-se menos aos seus significados que aos seus efeitos sensíveis. 
Interessante notar que logo antes de expor essa teoria que se dá na cabeça do padre, é feita a intervenção metaficcional na qual o leitor recebe um "aviso", por assim dizer, do narrador, que ao associar a cabeça da figura eclesiástica ao Corcovado e aos "Himalaias", afirma que nem um nem outro são altos em si mesmos. Ou seja: o leitor é quem os mede ${ }^{73}$.

Com isso quero dizer que a "teoria da escrita" de "O cônego ou metafísica do estilo", se por um lado não faz referências diretas à noção de perspectivismo, por outro lado não deixa de ser a ela solidária - seja ao valorizar o corpo tanto em relação à consciência ou à Ideia, seja ao explicitar o raciocínio de que as coisas não são nada em si mesmas, isto é, não são coisas em si.

Em última análise, o que está em jogo no conto em questão é a própria ideia / noção de metafísica: a "metafísica do estilo" não corresponde nem às "ilusões da consciência" - para falarmos com o Deleuze das teses práticas de Espinosa - nem à perenidade dos valores eternos: ela se faz, pelo contrário, no que há de dinamicidade entre o elemento sensório-corporal e o embate constante de forças em relação.

Em certo sentido, pode-se dizer que esses mesmos elementos podem ser observados tanto em "Ideias de Canário" como em "Um esqueleto" - embora representados de outra maneira nos respectivos enredos. Quanto ao primeiro, trata-se do investimento machadiano no elemento sensível (no caso, o trilar sonoro do pássaro) que, assim como em "O cônego ou metafísica do estilo", perspectiva os sentidos do mundo / das coisas.

Quanto ao segundo ["Um esqueleto"], trata-se do investimento, via humor negro, em toda uma poética das superfícies que, malgrado o julgamento moral que por ventura se possa fazer em relação ao protagonista do conto, tem como uma de suas provocações a desierarquização da alma em relação ao corpo - e, por consequência, a desarticulação do sistema de julgamento $\mathrm{Bem} / \mathrm{Mal}$ em proveito dos modos de existência bom/mau; os quais, segundo Deleuze, consistem na capacidade que cada pessoa, mediante encontros por ela mesma organizados e/ou agenciados, é capaz de compor (boas) relações: Belém, excêntrico professor de alemão, conserva em casa o esqueleto de sua falecida mulher - para escândalo tanto de seu aluno Alberto quanto de sua atual esposa, a viúva Marcelina. Pelo

\footnotetext{
${ }^{73}$ Cf. Capítulo 4.
} 
esqueleto, nutre verdadeira adoração; adoração essa que se apresenta, na dinâmica enunciado-enunciação do conto, como "demonstração" da existência da alma (que se dá, tal como no clássico conto "O espelho", via apelo corporal).

No prefácio a Missa do Galo: variações sobre o mesmo tema, o escritor Osman Lins menciona o termo homenagem. Luiz Antonio Aguiar, responsável pela organização de Recontando Machado, faz o mesmo ao justificar a razão de ser dessa proposta editorial da Record: "O sentido, obviamente, é "render homenagem" ao fato de os contos de Machado permanecerem tão férteis" (Aguiar, 2008, p.9).

Aproveitei, pois, essa ideia de fertilidade para explorar outro sentido do termo "homenagem". Trata-se do sentido proposto por Roberto Corrêa dos Santos em No contemporâneo: arte e escritura expandidas ${ }^{74}$ :

- "Homenagem: atitude estética e política deliberada de estabelecimento de modos específicos de relações amorosas com as obras alheias".

- "Homenagem: valer-se de estratégias discursivas diversas fortificando o impulso de criar diante do outro escolhido (atos de deferência e admiração como nutrientes éticos)" (Santos, 2011, p. 40).

Tais foram os sentidos, pois, que adotei para pensar os procedimentos de "De dentro do ovo para dentro da gaiola" e "Carta de uma mulher apaixonada". Isso significa dizer que procurei valorizar nos contos em questão aqueles aspectos que, servindo-se dos "nutrientes éticos" encontradiços nas narrativas de Machado de Assis, possuem, por sua vez, aquela "força ética de transformação" debatida por Karl Erik Schфollhammer em Ficção brasileira contemporânea. Isto é: sendo referenciais sem serem, necessariamente, representativas (no sentido de um realismo comprometido tanto com as técnicas da verossimilhança quanto com programas político-ideológicos generalizantes), busquei valorizar nas narrativas que escolhi os aspectos, traços e/ou operadores críticos que possuíssem, assim como na ficção de Machado de Assis, alcance epistemológico.

\footnotetext{
${ }^{74}$ Cf. Capítulo 6.
} 
Como proposto acima, sublinho que minha intenção, de modo algum, foi generalizar. Contudo, ao observar um conto - "Um esqueleto" - que em 1875 já trabalhava, de certo modo, com tópicos semiológicos que seriam trabalhados sete anos depois no conto-teoria "O espelho", dez anos depois em "O cônego ou metafísica do estilo", e vinte anos depois em "Ideias de Canário"; pois ao observar esses movimentos sutis mas insistentes, - gestos repetidos que apontam para a mesma valorização das superfícies, - creio não ser exagero dizer que Machado, não raro, lida com problemas epistemológicos em sua ficção ${ }^{75}$ - espaço pensante em que a prática escritural dramatiza sua intransitividade (no sentido de se apresentar como concretude formal arredia tanto a generalizações como aos conteúdos coercitivos da escrevência, para falarmos, ainda uma vez, com Roland Barthes). Como lembra Roberto Corrêa dos Santos, Machado de Assis “cria sem cessar valores para avaliar valores".

Nesse sentido, penso que tanto Marcelino Freire como Tatiana Salem Levy lançam mão, cada qual a seu modo, de radicalizações. Não se trata, aqui, de radicalizações teórico-críticas - em si mesmas radicais já na escrita machadiana -, mas de radicalizações temático-formais que levam em consideração os aspectos materiais das narrativas e seus efeitos no complexo dinâmico autor-texto-leitor.

Assim é que Freire, a meu ver, amplifica uma frase de "Ideias de Canário" proferida pelo cientista positivo Macedo - "todo eu era canário" - e a faz funcionar como devir-música e devir-pássaro em toda sua narrativa. Em "De dentro do ovo para dentro da gaiola", conto em que, da sintaxe à escolha lexical e desta última ao enredo, tudo é pássaro, um motorista pela grande São Paulo é posto em contato com a potência sonoro-desconstrutora dos "gorjeios" desarticulados de um morador de rua. Este último, por sua vez, perspectivando os códigos éticos da cidade grande, propõe outro modo (eu diria: outra ética de vida) de se lidar com todo aquele complexo social, entre a indiferença do guarda, o trânsito frenético, e as vontades de pacificação do motorista assoberbado. Tal como o canário de Machado de Assis, o morador de rua de Marcelino Freire dono da cidade - repete incessantemente, como um mantra, o bordão machadiano: "o canário, dono do mundo, habita gaiola vasta, branca e circular, donde mira o resto. Tudo o mais é ilusão e mentira”. Ao fazê-lo, se por um lado não leva a cabo

\footnotetext{
${ }^{75}$ Opinião, também, de José Raimundo Maia Neto, em O ceticismo na obra de Machado de Assis.
} 
grandes transformações, por outro lado faz com que algo de inominável se passe entre si e o motorista-narrador. Algo a que Gilles Deleuze, assim suponho, chamaria um estilo - potência desubstancializadora e crítica dos códigos linearizados pela moral vigente.

Tatiana Salem Levy, do mesmo modo, radicaliza as insinuações de "Um esqueleto" e, ali onde o professor Belém "demonstra" a existência da alma através da adoração dos ossos (do corpo), a personagem Marcelina, a partir de sua paixão homoerótica pelos ossos da finada Luísa, propõe outro conceito para a ideia de "eternidade" - uma eternidade que se dá pela união não do que no ser humano há de inalterado, idêntico, essencial, mas pela união daquilo que é mineral, ausente, vibrante. Ao fazê-lo, como diz a personagem, não precisa esperar pela morte. Pelo contrário, vai vivendo "sem pressa nem receio", no meio da floresta, seu amor com o esqueleto - em afirmação tanto do instante quanto da vida.

Em suma: retirar nutrientes éticos da obra do outro (como proposto ao início dessas considerações) é saber compor relações entre esta e a arte que se faz. Sem deixar de "ser o que se é" - como propõe Roberto Corrêa dos Santos -, homenagear, paradoxalmente, é poder fazer com que o estilo (a escrita), ao deixarse contaminar pelo que há de forte na obra do outro, crie seus próprios artefatos, seus gestos que, tomando consciência de si no em se fazendo do processo criativo, criam possíveis. Se não pude observar tal movimento nas obras de Marcelino Freire e de Tatiana Salem Levy (e nem essa era a proposta), pude fazê-lo, em certa medida, no que toca aos contos machadianos que escolhi - os quais, apesar dos temas diferentes, possuem constantes semiológicas semelhantes: força que aponta para a superfície desestabilizadora de todo valor perene.

José Raimundo Maia Neto propõe que Machado de Assis lida com problemas epistemológicos em sua ficção: “(...) Machado lida com problemas epistemológicos ao longo de toda a sua ficção e desenvolve uma solução cética para eles" (Maia Neto, 2007, p. 31). Eu também penso que sim. Mas creio que o ceticismo, em seu caso, seja antes uma referência que um ponto de chegada: em que pese o "tédio às controvérsias" do conselheiro Aires, me parece que a ataraxia, no caso de Machado, é uma figura excessivamente conciliadora.

Mais adequada que esta, talvez, seja uma outra, anunciada nos primeiros parágrafos de "O cônego ou metafísica do estilo": "Nesse dia - cuido que por volta de 2222 - o paradoxo despirá as asas para vestir a japona de uma verdade 
comum. Então esta página merecerá, mais que favor, apoteose (...) (Assis, 2008, p. 528).

Enquanto tal não acontece, convoco para essas considerações finais (que são antes um balanço que se pretende deixar em aberto) uma citação de Gilles Deleuze: "É contudo aí que se opera a doação de sentido, nesta região que precede todo bom senso e senso comum. Aí, a linguagem atinge sua mais alta potência com a paixão do paradoxo" (Deleuze, 1974, p. 81). 


\section{8 \\ Referências bibliográficas}

AGAMBEN, G. "Genius”. In: Profanações. São Paulo: Boitempo, 2007.

AGUIAR, L. A. (Org.). Recontando Machado. Rio de Janeiro: Record, 2008.

ANDRADE, S. A. de et al. Um homem célebre: Machado recriado. São Paulo: Publifolha, 2008.

ASSIS, M. de. Obras completas em quatro volumes. Rio de Janeiro: Nova Aguilar, 2008.

BARTHES, R. Novos ensaios críticos seguidos de o grau zero da escritura. São Paulo: Cultrix, 1986.

Aula. São Paulo: Cultrix, 2007.

Brasiliense, 1990. Sade, Fourier, Loyola. São Paulo, Editora

CAMPOS, H. de. "Arte pobre, Tempo de Pobreza, Poesia Menos"; "Da Razão Antropofágica: Diálogo e Diferença na Cultura Brasileira"; "Sobre Roland Barthes". In: Metalinguagem \& outras metas. São Paulo: Perspectiva, 2006.

CANDIDO, A. "Um instrumento de descoberta e interpretação". In:

Formação da literatura brasileira. Belo Horizonte: Itatiaia; São Paulo: Editora da Universidade de São Paulo, 1975.

CARVALHO, C. de. Dicionário de Machado de Assis: língua, estilo, temas. Rio de Janeiro: Lexikon, 2010.

CHIGRES, C. F. A cura pela palavra: os ensaios de Montaigne e as lembranças de Tocqueville. Dissertação de Mestrado. Rio de Janeiro: Pontifícia Universidade Católica do Rio de Janeiro, 1995.

COMPAGNON, A. "O estilo". In: O demônio da teoria: literatura e senso comum. Belo Horizonte: UFMG, 2010. 
COSTA LIMA, L. "Machado: mestre de capoeira". In: Intervenções. São Paulo: Editora da Universidade de São Paulo, 2002.

DELEUZE, G. “O trágico". In: . Nietzsche et La philosophie. Paris: Presses Universitaires de France, 1973. Tradução portuguesa: DELEUZE, G. Nietzsche e a filosofia. Trad Antonio M. Magalhães. Porto: Res, s/d.

. "Décima Segunda Série: Sobre o Paradoxo". In: Lógica do sentido. São Paulo: Perspectiva, 1974.

" "A vida como obra de arte". In: Conversações. São Paulo: Ed. 34, 1992. "A literatura e a vida" In: Crítica e clínica. São Paulo: Ed. 34, 1997. "Sobre a diferença da Ética em relação a uma Moral". In: Espinosa: filosofia prática. São Paulo: Escuta, 2002.

DELEUZE, G.; PARNET, C. “Uma Conversa, o Que É, Para Que É Que Serve?”. In: Diálogos. Lisboa: Relógio D’água, 2004.

DELEUZE, G.; GUATTARI, F. "Percepto, afecto e conceito". In: O que é a filosofia? Rio de Janeiro: Ed. 34, 1992. "20 de Novembro de 1923 - Postulados da Linguística". In: Mil platôs: capitalismo e esquizofrenia, v.2. São Paulo: Ed. 34, 1995. "1837 - Acerca do ritornelo". In: Mil platôs: capitalismo e esquizofrenia, v.4. São Paulo: Ed. 34, 1997.

DOURADO, A. "Provocação do visitante". In: As imaginações pecaminosas. Rio de janeiro: Rocco, 2005.

FERNANDES, R. (Org.). Capitu mandou flores. São Paulo: Geração Editorial, 2008.

FOUCAULT, M. "Nietzsche, a genealogia e a história". In: Microfísica do poder. Rio de Janeiro: Graal, 1979. “A prosa do mundo". In: As palavras e as coisas. São Paulo: Martins Fontes, 2007.

GOMES, R. C. "Singulares ocorrências: claro enigma de uma ficção". In. DINIZ, J. (Org.). Machado de Assis (1908-2008). Rio de Janeiro: Ed. PUC-Rio: Contraponto, 2008. 
KRAUSE, G. B. "Machado de La Mancha contra o gigante do realismo". In:__ DINIZ, J. (Org.). Machado de Assis (1908-2008). Rio de Janeiro: Ed. PUC-Rio: Contraponto, 2008.

Rocco, 2011.

O problema do realismo de Machado de Assis. Rio de Janeiro:

LACOUE-LABARTHE, P.; NANCY, J. "A exigência fragmentária". Terceira Margem. Revista do Programa de Pós-Graduação em Ciência da Literatura da UFRJ, Ano IX, n 10, 2004.

LINS, O. (Org.). Missa do galo. Variações sobre o mesmo tema. São Paulo: Summus, 1977.

MAIA NETO, J. R. O ceticismo na obra de Machado de Assis. São Paulo: Annablume, 2007.

MARINATO, A. C. L. Autor, narrador, personagem: as várias facetas dos Aires de Machado. Dissertação de Mestrado. Vitória, 2013: UFES.

MELO SOBRINHO, N. C. de. "Friedrich Nietzsche: perspectivismo e superação da metafísica". In: janeiro/junho 2004. . Revista Comum. Rio de Janeiro: v.9, n. 22, p. 5- 38,

MELVILLE, H. Bartleby, o escrivão. Rio de Janeiro, José Olympio, 2007.

MONTEIRO, A. "A literatura na ópera da vida". In: Verbo de Minas: Letras. Revista do Programa de Pós-Graduação do Centro de Ensino Superior de Juiz de Fora. CES/JF: Juiz de Fora, 2010.

OLIVEIRA, R. P. M. de. Machado de Assis: "o crítico dos outros e de si próprio". Dissertação apresentada ao Programa de Pós-Graduação em Letras: Estudos Literários, área de concentração em Teorias da Literatura, da Faculdade de Letras da Universidade de Juiz de Fora. Juiz de Fora, 2011.

PERRONE-MOISÉS, L. Texto, crítica, escritura. São Paulo: Ática, 1978.

PLATÃO. Apologia de Sócrates. Coleção Os Pensadores. São Paulo: Nova Cultural, 1996.

SANTIAGO, S. "Permanência do discurso da tradição no modernismo". In: BORNHEIM, G. et al. Tradição/Contradição. Rio de Janeiro: Zahar; FUNARTE, 1987.

SANTOS, R. C. dos. "Pensar escritores, Machado a exemplo". In: Modos de saber, modos de adoecer. Belo Horizonte: Ed. UFMG, 1999. 
SANTOS, R. C. dos. No contemporâneo: arte e escritura expandidas. Rio de Janeiro: Circuito: FAPERJ, 2011.

SCHØLLHAMER, K. E. "Que significa literatura contemporânea?”; “O realismo de novo"; "Os perigos da ficção". In:

Rio de Janeiro: Civilização Brasileira, 2009. Ficção brasileira contemporânea.

WISNIK, J. M. "Machado Maxixe". In: Sem receita. São Paulo: Publifolha, 2004. 